UNIVERSIDADE DE SÃO PAULO

ESCOLA DE ENGENHARIA DE SÃO CARLOS

RAFAELA FACIOLA COELHO DE SOUZA

Migração de Poluentes Inorgânicos em Liners Compostos

São Carlos 

RAFAELA FACIOLA COELHO DE SOUZA

\section{Migração de Poluentes Inorgânicos em Liners Compostos}

Dissertação apresentada ao Departamento de Geotecnia da EESC-USP como parte dos requisitos necessários à obtenção do título de Mestre em Geotecnia.

Área de Concentração: Geotecnia

Orientador: Prof. Dr. Osni José Pejon

São Carlos 
TRABALHO, POR QUALQUER MEIO CONVENCIONAL OU ELETRÔNICO, PARA FINS DE ESTUDO E PESQUISA, DESDE QUE CITADA A FONTE.

Ficha catalográfica preparada pela Seção de Tratamento da Informação do Serviço de Biblioteca - EESC/USP

$\mathrm{s} 729 \mathrm{~m}$

Souza, Rafaela Faciola Coelho de

Migração de poluentes inorgânicos em liners compostos / Rafaela Faciola Coelho de Souza ; orientador Osni José Pejon. -- São Carlos, 2009.

Dissertação (Mestrado-Programa de Pós-Graduação e Área de Concentração em Geotecnia) -- Escola de Engenharia de São Carlos da Universidade de São Paulo, 2009.

1. Solo argiloso. 2. Geocomposto bentonitico (GCL).

3. Liner composto. 4. Transporte de poluentes. I. Título. 
FOLHA DE JULGAMENTO

Candidata: Bacharel RAFAELA FACIOLA COELHO DE SOUZA.

Dissertação defendida e julgada em 17/11/2009 perante a Comissăo Julgadora:

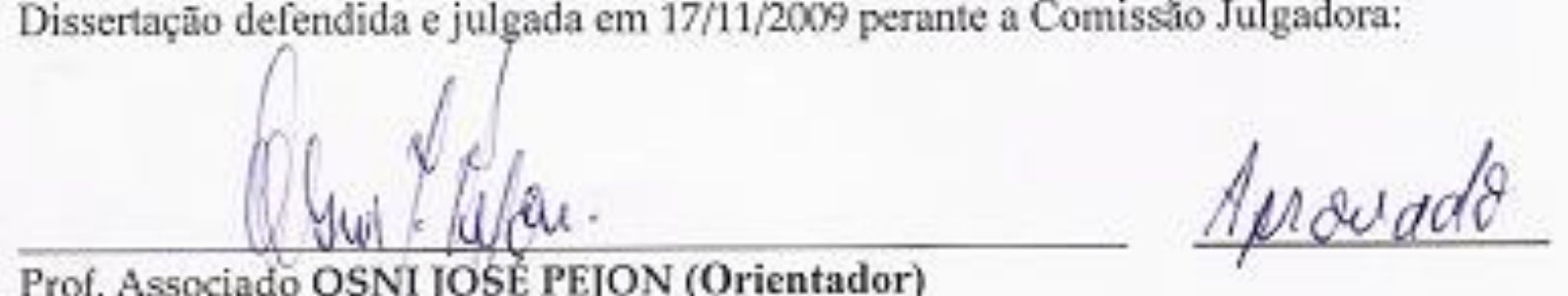

Prof. Associado OSNI JOSÉ PEJON (Orientador)

(Escola de Engenharia de Sào Carlos/USP)

Eommania Jicinas Abrando

Prof ${ }^{2}$. Dr ${ }^{1}$. ENY MARIA VIEIRA

(Instituto de Quimica de São Carlos/USP)

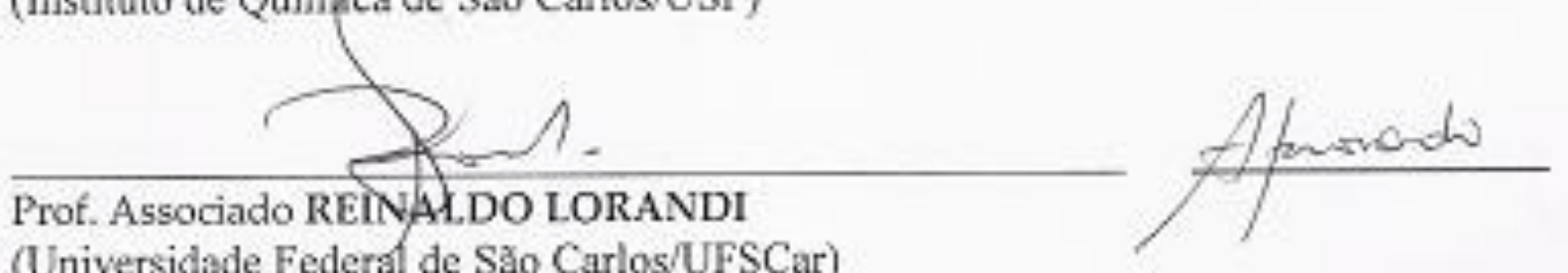

(Universidade Federal de Săo Carlos/UFSCar)

Prof. Associado LAZARO WAGENTIN ZUQUETTE

Coordenador do Programa de Pós-Graduaçăo em

Geoterenia

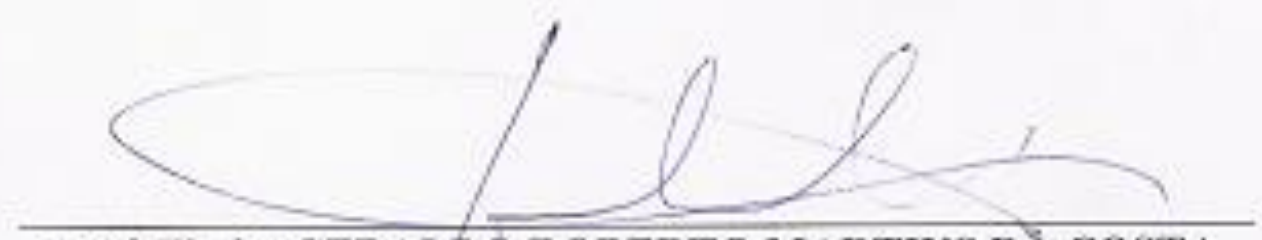

Prof. Titular GERALDO ROBERTO MARTINS DA COSTA Presidente da Comissào da Pós-Graduação da EESC 



\section{DEDICATÓRIA}

À minha Família, que sempre acreditou e confiou em mim. E ao meu noivo Aref por estar sempre ao meu lado compartilhando desta caminhada. 



\section{AGRADECIMENTOS}

Ao Conselho Nacional de Pesquisa (CNPq) pela bolsa de estudos concedida para o desenvolvimento da pesquisa de mestrado.

Ao Departamento de Geotecnia da Escola de Engenharia de São Carlos por me receber como aluna de pós-graduação.

Ao professor Dr. Osni José Pejon pela orientação, paciência, e por depositar confiança em mim durante a pesquisa.

Ao professor Dr. Lázaro Valentim Zuquette pela recepção em São Carlos e no departamento, disponibilizando ajuda e atenção na minha estadia.

Ao Sr. Antônio Garcia, técnico do Departamento de Geotecnia, por toda atenção, auxílio e apoio constante durante a realização dos ensaios e por todas as análises físicoquímicas na Geoquímica. E pela sua amizade e conselhos durante o desenvolvimento do trabalho.

Ao amigo, Marcos Musso, por todo auxílio, discussões enriquecedoras, e valiosas sugestões.

Ao professor Dr. Antenor Braga Paraguassú pelas sugestões e pela atenção sempre que precisei.

Ao técnico do Laboratório de Geossintéticos da Escola de Engenharia de São Carlos, Klever Valentim, pela disponibilidade e ajuda na extração de solução dos corpos-de-prova.

À aluna de iniciação científica, Juliana, por realizar as leituras dos meus ensaios para que eu pudesse passar o Natal com a família.

A todos os professores, técnicos e funcionários do Departamento de Geotecnia pela atenção e apoio durante o desenvolvimento do trabalho.

Aos meus amigos São Carlenses, Aline Zuquetinha, Dani Cenci, Jú Maria, Dani Japa, Cynthia, Elaine, Felipe, Léo, Simone, Marcilene, Natália, Márcia, Damares, Karin, Lisandra, Wanessão, Lú, Val, Jú Lukiantchuki, Giovana, Sérgio Baiano, Vagner, Aleones, Nene, em especial, à Marla, por fazer leituras nos meus ensaios e pela companhia no "calabouço". 
Ao povo do Paraty, minhas vizinhas queridas, Carol, Carla, Bianca, Ana Claudia, Eliana, Ana Paula, Lívia e Grá por me receber de braços abertos e me proporcionar vários reuniões descontraídas.

Agradeço ao meu noivo, Aref Kzam, pela companhia em São Carlos, ajuda quando eu fiz as disciplinas, apoio constante durante a realização da minha pesquisa, pelo cuidado e compreensão nesta fase importante da minha vida.

Aos meus pais, Lina e Sérgio, por acompanharem de longe a minha caminhada, sempre buscando me dar força e proteção. Ao meu irmão Serginho, por torcer pelo meu sucesso. Eles me fizeram descobrir o caminho certo!

Aos meus avôs queridos, que sempre rezaram por mim e me deram todo apoio nesta caminhada, assim como, meus tios, tias, primos e primas.

A Deus, por me guiar e iluminar sempre. À Santa Teresinha do Menino Jesus e a Nossa Senhora de Nazaré por escutar e atender as minhas preces. 

“Toda nova solução que apresenta menos problemas que soluções tradicionais, deve ser considerada uma evolução.”

Giroud (2005) 


\section{RESUMO}

SOUZA, R. F. C. Migração de poluentes inorgânicos em liners compostos, 2009. 100 f. Dissertação (Mestrado) - Escola de Engenharia de São Carlos, Universidade de São Paulo, 2009.

Neste trabalho analisa-se o comportamento de duas configurações de liners através da percolação com solução de $\mathrm{KCl}$. São utilizadas amostras de solo compactadas, do interior do estado de São Paulo, provenientes da Formação Corumbataí, combinadas a um geocomposto bentonítico (GCL) de fabricação nacional. São utilizados ensaios em coluna de percolação em dois corpos-de-prova, nas configurações: solo compactado acima do GCL e solo compactado abaixo do GCL. Esses ensaios permitiram a determinação da condutividade hidráulica e dos parâmetros de transporte dos materiais estudados. Dessa forma, compara-se o comportamento desses materiais combinados com os resultados obtidos por Musso (2008), que adotou a configuração independente. Após o início da percolação com solução $\mathrm{KCl}$ a condutividade hidráulica $(K)$ das duas configurações apresentou comportamento crescente. No entanto, este aumento no $K$ não afetou o desempenho hidráulico dos materiais, e a condutividade hidráulica mostrou-se com valores da ordem de $10^{-11} \mathrm{~m} / \mathrm{s}$. O fator de retardamento da configuração na qual o GCL encontra-se acima da camada de solo compactado se mostrou maior com relação à outra configuração analisada. No geral, considerou-se que esta configuração apresentou melhor desempenho como liner composto. $\mathrm{Na}$ comparação dos resultados obtidos nesta pesquisa com os apresentados por Musso (op. cit.) a condutividade hidráulica não diferiu, e as configurações de liner compostos apresentaram maiores fatores de retardamento do que o liner do solo compactado isoladamente.

Palavras-chave: Liner Composto; Transporte de poluentes; Ensaios em Coluna; Geocomposto Bentonítico; Solo Compactado. 


\begin{abstract}
SOUZA, R. F. C. Migration of pollutant inorganic through composite liners, 2009. 100 f. Master Dissertation - Escola de Engenharia de Sao Carlos, Universidade de Sao Paulo, 2009.

This research analyzes the behavior of two sets of liners subjected to the percolation of $\mathrm{KCl}$ solution. Samples of compacted soil from Corumbataí Formation, combined with a geosynthetic clay liner (GCL) of Brazilian manufacture were used. Column percolation tests were used in two specimens, in the settings: compacted soil above the GCL and compacted soil below the GCL. These tests allowed the determination of hydraulic conductivity and transport parameters of the materials under study. Thus, the behavior of these composite liners was compared with the results obtained by Musso (2008), which tested the independent configuration. After the start of percolation of the $\mathrm{KCl}$ solution the hydraulic conductivity $(K)$ of the two settings showed an increase. However, this increase in $K$ did not affect the hydraulic performance of materials, and the hydraulic conductivity was observed with values of about $10^{-11} \mathrm{~m} / \mathrm{s}$. The retardation factor of the configuration in which the GCL is above the layer of compacted soil was larger in relation to the other configuration analyzed. Overall, it was considered that this configuration showed better performance as composite liner. Comparing the results with those presented by Musso (2008), the hydraulic conductivity didn't differ, and the composite liners had higher retardation factors than the liner of compacted soil alone.
\end{abstract}

Key Words: Composite liners; Transport of pollutant; Colum Test; Geosynthetic Clay Liner (GCL); Compacted Soil. 


\section{LISTA DE FIGURAS}

Figura 2.1 - Partes físicas principais que compõem um aterro sanitário (IPT, 1995). 28

Figura 2.2 - Sistemas de impermeabilização inferior para aterros de RSU considerando diferentes regulamentações e recomendações (Ferrari, 2005 modificado de Manassero, 1997).

Figura 2.3 - Esquema de aterros de resíduos sólidos urbanos, sem impermeabilização na base (CETESB, 1993). a) Condições climáticas e hidrogeológicas favoráveis. b) Condições climáticas insatisfatórias e hidrogeológicas favoráveis.

Figura 2.4 - Esquema de aterros de resíduos sólidos urbanos, com necessidade de impermeabilização na base (CETESB, 1993). a) Condições climáticas e hidrogeologia favoráveis. b) Condições climáticas e hidrogeologia insatisfatórias.

Figura 2.5 - Esquema de um aterro sanitário mostrando tipos de impermeabilizantes utilizados em resíduos perigosos (CETESB, 1993).

Figura 2.6 - Configuração do GCL FORTLINE fabricado pela OBER (modificado do Boletim Técnico Ober).

Figura 2.7 - Configuração para sistemas de base de aterros (Sharma \& Lewis, 1994).

Figura 2.8 - Intervalos típicos de condutividade hidráulica obtidas em campo e laboratório de materiais que podem ser aplicados como liner (Folkes, 1992).

Figura 2.9 - (a) Barreira argilosa compactada; (b) Sistema composto de Geomembrana + argila compactada; (c) Sistema composto de Geomembrana + GCL + argila compactada (Koerner, 1999).

Figura 2.10 - Alteração da estrutura do solo devido à energia e umidade de compactação, apresentado por Lambe (modificado de Pinto, 2002)..... 46

Figura 2.11 - Variação da condutividade hidráulica devido ao aumento da energia de compactação (Mitchell et. al.,1965). 46 
Figura 2.12 - Variação da condutividade hidráulica e massa específica seca em função do teor de umidade (Mitchell et. al., 1965).

Figura 2.13 - Modelo dos torrões de Olsen (1962, modificado de Daniel \& Benson, 1990).. 48

Figura 2.14 - Metodologia para determinar a zona adequada em termos de teor de umidade $\left(\mathrm{w}_{\mathrm{ot}}\right)$, massa específica seca $\left(\rho_{\mathrm{d}}\right) \mathrm{e}$ condutividade hidráulica $(\mathrm{K})$ (Daniel \& Benson, 1990).... 48

Figura 2.15 - Metodologia para determinar a zona admissível: (a) curva de compactação para as três energias; (b) resultados de condutividade hidráulica em função do teor de umidade (Benson \& Daniel, 1990). 50

Figura 2.16 - Metodologia para determinar a zona admissível: (a) replotagem da curva de compactação com valores de condutividade hidráulica aceitáveis; (b) modificação da zona admissível de acordo com os fatores preponderantes (Benson \& Daniel, 1990). 50

Figura 2.17 - Mecanismos da dispersão hidrodinâmica: (a) velocidade diferencial da solução interporos; (b) caminhos do fluxo tortuoso; e (c) mecanismo da difusão molecular atuando nos canais dos poros (Modificado de Freeze \& Cherry, 1979). 54

Figura 2.18 - Dispersão longitudinal de um soluto através de uma coluna de solo: (a) coluna com fluxo permanente e fonte contínua; (b) interface entre as concentrações no instante t0; (c) concentração relativa do soluto no efluente da coluna (adaptado de Freeze \& Cherry, 1979).55

Figura 2.19 - Conceito de comprimento efetivo no transporte em solo (Schakelford \& Daniel, 1991a). 58

Figura 2.20 - Dupla camada elétrica e partícula de argila carregada negativamente (modificado de Oliveira, 2002).

Figura 2.21 - Isoterma linear (Rowe et al, 1995).

Figura 2.22 - Isoterma de Freundlich: (a) sorção como função da concentração; (b) Representação gráfica para determinação dos parâmetros (Rowe et. al., 1995). 65

Figura 2.23 - Isoterma de Langmuir: (a) sorção em função da concentração; (b)representação gráfica para determinação dos parâmetros (Rowe et. al., 1995). 66 
Figura 2.24 - Determinação do fator de retardamento, $R_{d}$. (Shackelford, 1994)

Figura 3.1 - Mapa de localização das coletas de amostras de solo da Formação Corumbataí (Musso, 2008)

Figura 3.2 - Equipamento para ensaio em coluna: (a) painel com dispositivos para o controle da pressão; (b) reservatório para recarga de solução contaminante; (c) coluna de percolação e coletor de efluentes.

Figura 3.3 - Projeto de construção do corpo-de-prova: (a) Detalhes da tampa a ser fixada na base e topo do cilindro; (b) Dimensões do corpo-de-prova; (c) Detalhe da concavidade moldada nas tampas para servir de reservatório.

Figura 3.4 - Equipamento para compactação do corpo-de-prova na célula de percolação: (a) peças componentes da célula de percolação; (b) peças componentes para a compactação do solo no cilindro de acrílico; (c) compactador de amostras.

Figura 3.5 - (a) cilindro com base e tampa de acrílico para compactar o solo; (b) peças componentes da célula: malha \# 400 mesh (1), mangueira (2), pedras porosa (3) e o-rings (4).

Figura 3.6 - (a) Corte do GCL fabricado pela empresa OBER; (b) GCL cortado na dimensão da célula de percolação.

Figura 3.7 - Frascos de armazenamento das soluções coletadas para análise físico-química. 85

Figura 3.8 - Esquema geral do equipamento para ensaio em coluna. 86

Figura 3.9 - Partes do equipamento componentes do processo de recarga de solução contaminante.

Figura 3.10 - Fotômetro de chama da marca MICRONAL, modelo B262.

Figura 3.11 - Espectrofotômetro da marca HACH modelo 2010. 90

Figura 3.12 - Equipamentos para análises químicas: (a) Eh; (b) pH; (c) CE 91

Figura 3.13 - Sistema de extração com pórtico de reação, macaco hidráulico, célula de carga, sistema embolo + câmara e seringa. 92 
Figura 4.1 - (a) ATD da amostra de solo; (b) ATD da bentonita do GCL (Musso, 2008)...... 94 Figura 4.2 - (a) Difração de Raio X da amostra de solo; (b) Difração em Raio X da bentonita do GCL (Marques, 2009) 94

Figura 5.1 - Curva de chegada do $\mathrm{K}^{+}$nos corpos-de-prova ensaiados. 109

Figura 5.2 - Curva de chegada dos íons $\mathrm{K}+$ e Cl- para amostra de solo compactado obtida por Musso (2008). 110

Figura 5.3 - Curva de chegada dos íons K+ e Cl- para o GCL obtida por Musso (2008). .... 110

Figura 5.4 - Curva de chegada dos íons $\mathrm{K}^{+}$e $\mathrm{Cl}^{-}$do ensaio CP-1 para cálculo do fator de retardamento

Figura 5.5 - Curva de dos íons $\mathrm{K}^{+}$e $\mathrm{Cl}^{-}$do ensaio CP-2 para cálculo do fator de retardamento.

Figura 5.6 - Curva de do íon $\mathrm{K}^{+}$do ensaio $\mathrm{CP}-2$ com $\mathrm{C} / \mathrm{C}_{0}=0,95$ para cálculo do fator de retardamento 113 


\section{LISTA DE TABELAS}

Tabela 2.1 - Condutividade hidráulica dos argilominerais (Mesri \& Olson, 1971). 44

Tabela 2.2 - Valores típicos de condutividade hidráulica em relação ao tipo de solo (Pinto, 2002) 45

Tabela 2.3 - Gradiente hidráulico recomendado (ASTM D5084-90). 51

Tabela 4.1 - Caracterização física da amostra de solo e do GCL. 93

Tabela 4.2 - Caracterização físico-química da amostra de solo e do GCL (Musso, 2008) ....93

Tabela 4.3 - Características dos corpos-de-prova e dos ensaios em coluna. 95

Tabela 5.1 - Resultado do comportamento dos ensaios desta pesquisa.... 109

Tabela 5.2 - Resultados do comportamento dos ensaios de Musso (2008). 111

Tabela 5.3 - Valores de $R_{d}$ obtidos nesta pesquisa 114

Tabela 5.4 - Valores de $R_{d}$ obtidos por Musso (2008). 114

Tabela 5.5 - Concentração da solução extraídas das amostras de solo após os ensaios. 115 



\section{LISTA DE ABREVIATURAS E SIGLAS}

$\begin{array}{ll}\text { ABNT } & \text { Associação Brasileira de Normas Técnicas } \\ \text { ASTM } & \text { American Society for Testing and Materials } \\ \text { ATD } & \text { Análise Térmica Diferencial } \\ \text { ATG } & \text { Análise Termo Gravimétrica } \\ \text { CCL } & \text { (barreira argilosa compactada) } \\ \text { CETESB } & \text { Companhia de Tecnologia de Saneamento Ambiental } \\ \text { CTC } & \text { Capacidade de Troca de Cátions } \\ \text { DBO } & \text { Demanda Bioquímica de Oxigênio } \\ \text { EPA } & \text { Environmental Protection Agency } \\ \text { EESC } & \text { Escola de Engenharia de São Carlos } \\ \text { IP } & \text { Índice de Plasticidade } \\ \text { IPT } & \text { Instituto de Pesquisas Tecnológicas } \\ \text { GCL } & \text { (Geocomposto bentonítico) } \\ \text { GM } & \text { Geomembrana } \\ \text { LL } & \text { Limite de Liquidez } \\ \text { PVC } & \text { Policloreto de Vinila } \\ \text { READ } & \text { Polietileno de Alta Densidade } \\ \text { PROSAB } & \text { Programa de Pesquisas em Saneamento Básico } \\ \text { RSUlidos Industriais }\end{array}$





\section{SUMÁRIO}

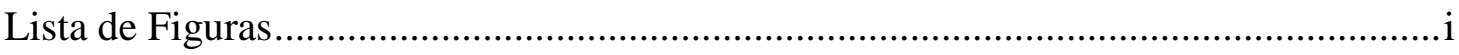

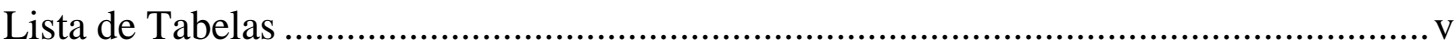

Lista de Abreviaturas e Siglas ................................................................................... vii

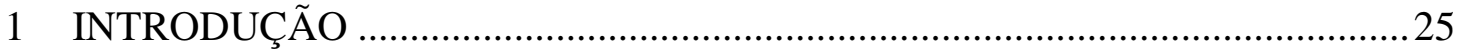

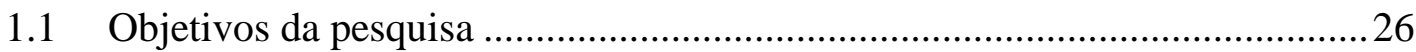

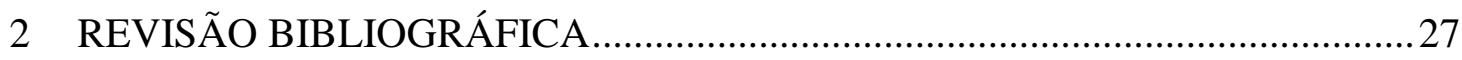

2.1 Disposição de resíduos............................................................................ 27

2.2 Revestimento de fundo em aterros (Liners) ................................................. 31

2.2.1 Especificações técnicas para a impermeabilização de aterros ................... 32

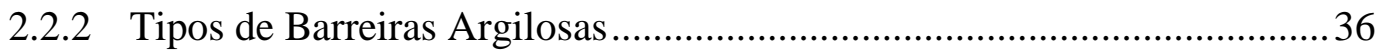

2.2.3 Condutividade Hidráulica em Liners .....................................................42

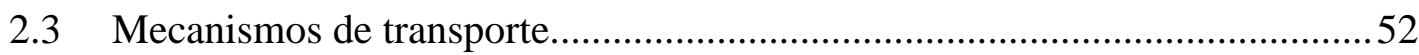

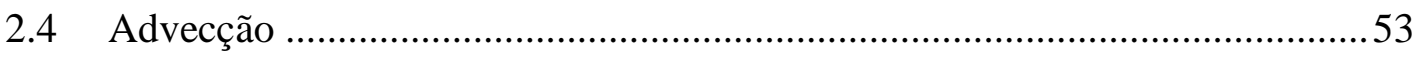

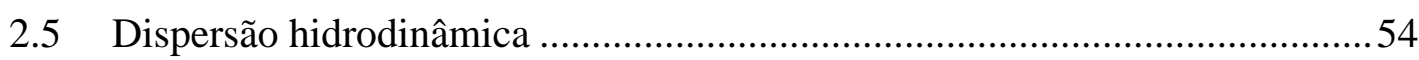

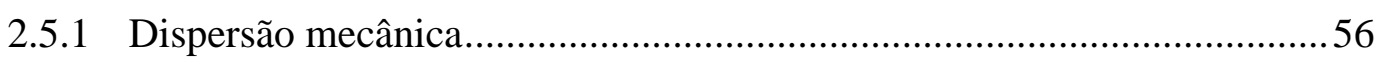

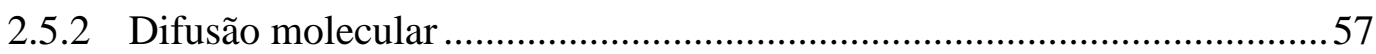

2.6 Mecanismos de interação solo-contaminante ................................................60

2.7 Modelo geral para transporte de poluentes ....................................................67

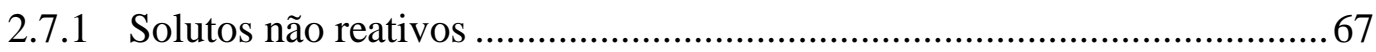

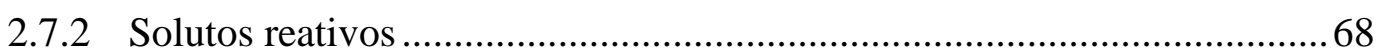

2.8 Técnicas experimentais na determinação dos parâmetros de transporte e atenuação. 68

2.8.1 Ensaio em coluna 69

2.8.2 Ensaio de equilíbrio em lote (Batch Test) ........................................... 71

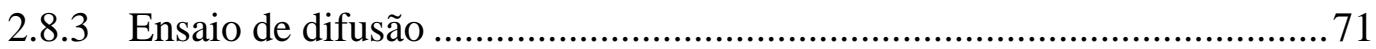

2.8.4 Ensaio de compatibilidade ................................................................. 72

2.1 Pesquisas realizadas no Departamento de Geotecnia ................................. 72

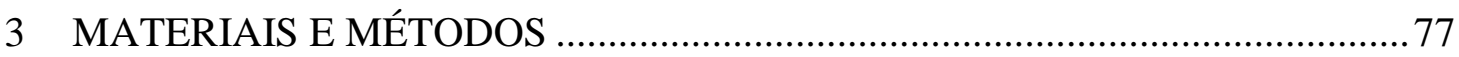

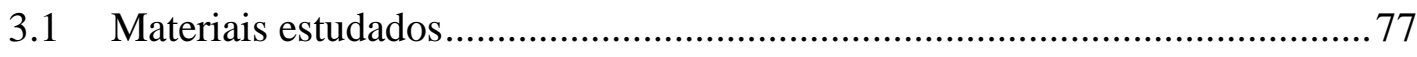

3.2 Caracterização do material e ensaio em coluna ............................................. 78

3.2.1 Equipamento para ensaio em coluna ......................................................... 78 


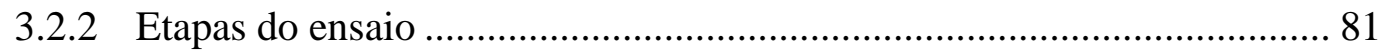

3.2.3 Extração de solução dos corpos-de-prova ............................................ 91

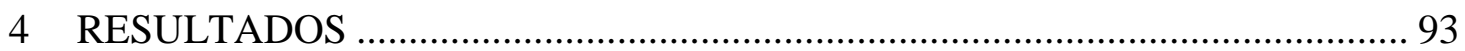

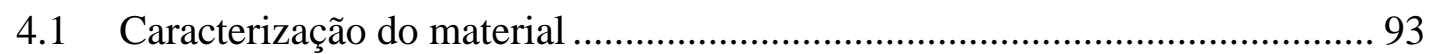

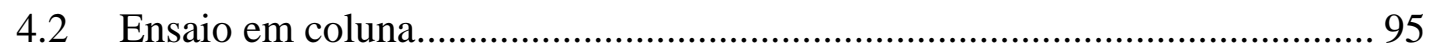

4.2.1 pH (potencial hidrogeniônico) .................................................................. 99

4.2.2 Condutividade elétrica....................................................................... 100

4.2.3 Potencial de oxi-redução (Eh) ........................................................... 101

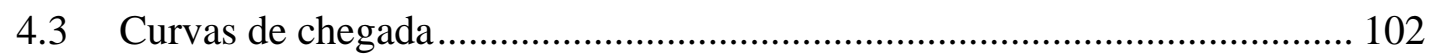

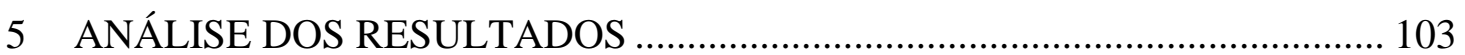

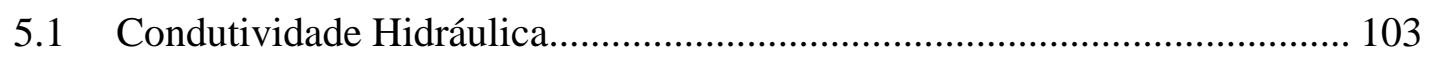

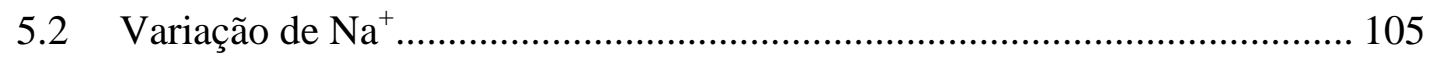

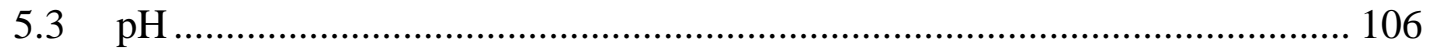

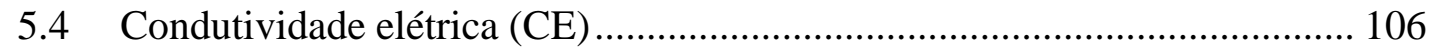

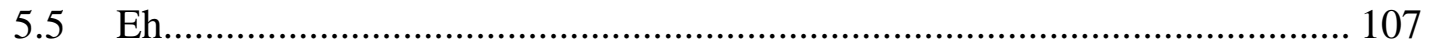

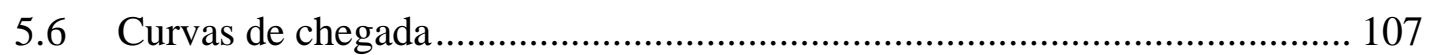

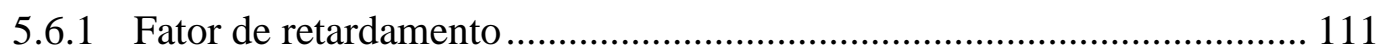

5.7 Extração de solução dos corpos-de-prova .................................................. 115

6 CONSIDERAÇÕES FINAIS E SUGESTÕES PARA FUTURAS PESQUISAS 117

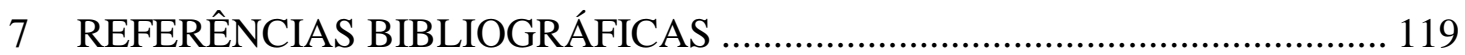




\section{INTRODUÇÃ̃o}

Utilizar novas técnicas que sejam menos agressivas ao meio ambiente é uma tentativa de minimizar os impactos ambientais causados pelas obras civis. A geração de resíduos sólidos, urbanos e industriais em grande escala, tornou-se um problema relacionado à sua disposição e decomposição. Isso ocorre pela constituição de substâncias capazes de contaminar o solo e as águas subsuperficiais, causando a degradação do meio ambiente. Por esta razão, necessitam de formas mais seguras de tratamento e disposição.

Atualmente, estudam-se novas tecnologias de implantação de sistemas adequados à disposição, devido aos danos provocados pelo armazenamento inadequada dos resíduos. Para tal fim, aplicam-se as barreiras impermeabilizantes em aterros sanitários, comumente conhecidas como "liners". A aplicação desse sistema de revestimento é uma forma de evitar a migração dos poluentes ao longo do perfil hidrogeológico através da separação física entre o resíduo disposto e a superfície do terreno. Dessa forma, é possível garantir a segurança contra a contaminação do lençol freático. Portanto, as barreiras impermeabilizantes trabalham absorvendo ou atenuando as substâncias nocivas suspensas ou dissolvidas no percolado.

Os "liners" são camadas construídas nas bases dos aterros, com materiais naturais (solo, areia, brita), ou com misturas industrializadas (membrana geossintéticas, geocomposto bentonítico etc.). Para a construção dos "liners" naturais, geralmente utilizam-se materiais argilosos, pois apresentam características peculiares ao sistema de impermeabilização. Estas peculiaridades estão relacionadas aos aspectos construtivos e á viabilidade econômica.

Boscov (1997) ressalta que não existe camada impermeabilizante totalmente impermeável. Mesmo que a concentração inicial do poluente sobre a superfície do terreno seja considerável, sempre atingirá o lençol freático com concentração não nula. Portanto, o sistema 
de revestimento deve garantir que a concentração do poluente no lençol subterrâneo esteja de acordo com os padrões não nocivos à saúde humana.

Neste contexto, realizam-se pesquisas com esses materiais, a fim de avaliar o comportamento físico-químico e hidráulico frente a soluções contaminantes. Esses estudos são realizados através de fluxos gerados pela exposição a gradientes químicos e hidráulicos. Desse modo, estudam-se algumas propriedades destes materiais relacionadas ao transporte e retenção de contaminantes.

Em razão da carência de pesquisas realizadas na avaliação de barreiras composta, optou-se por estudar a aplicação de amostras de solos argilosos do interior do estado de São Paulo com um geocomposto bentonítico (GCL) de fabricação nacional. Estes materiais foram escolhidos por apresentar características satisfatórias quanto à migração e atenuação de poluentes.

\subsection{Objetivos da pesquisa}

O objetivo principal é avaliar os mecanismos de transporte de contaminantes inorgânicos, através de um sistema de liner, composto de solo argiloso compactado (CCL) proveniente da Formação Corumbataí com um GCL fabricado no Brasil. A Formação Corumbataí foi escolhida por aflorar em regiões próxima às zonas de recarga do aquífero Guarani no interior do estado de São Paulo, e também nas regiões de Rio Claro, Piracicaba, Limeira e Pirassununga. O geocomposto bentonítico foi escolhido por ser o único GCL de fabricação nacional e também por ser relativamente pouco estudado. Os íons utilizados na simulação do transporte de contaminantes foram o $\mathrm{K}^{+}$e $\mathrm{Cl}^{-}$, por serem íons comuns em depósitos de rejeitos urbanos. Dessa maneira, foi possível dar continuidade nesta linha de pesquisa, o que permitiu a comparação com os resultados obtidos por Musso (2008) quando estes materiais foram estudados separadamente. 


\section{REVISÃO BIBLIOGRÁFICA}

\subsection{Disposição de resíduos}

A disposição de resíduos é uma das questões fundamentais relacionadas à proteção ambiental. Para tal fim, foram desenvolvidas técnicas construtivas responsáveis pela destinação final dos resíduos, os aterros. Vários aspectos são levados em consideração para a implantação de um aterro, onde os principais requisitos envolvem condicionantes do meio físico, seleção do local de disposição, diagnóstico da área contaminada, caracterização prévia do resíduo a ser armazenado, tipo de sistema de contenção e a migração dos contaminantes abrangendo os processos e mecanismos de transporte.

Os termos utilizados para as formas de disposição de resíduos conhecidos como lixão, aterro controlado e aterro sanitário caracterizam-se diferenciadamente. Segundo o IPT Instituto de Pesquisas Tecnológicas (1995), o lixão é uma forma inadequada de disposição final dos resíduos sólidos, que se caracteriza pela simples descarga sobre o solo a céu aberto, sem eventuais medidas de proteção na base e na cobertura, sem tratamento de gases e efluentes. Além disso, não há controle quanto aos tipos de resíduos depositados, apresentando esta medida de descarte um grande potencial de poluição. Já um aterro controlado, constituise em uma técnica de disposição de resíduos sólidos urbanos no solo, para reduzir os riscos ou danos à saúde pública. Neste caso, o impacto ambiental é minimizado com a utilização de recursos da engenharia, por meio do confinamento dos resíduos por um sistema de cobertura com uma camada de material inerte ao final de cada jornada de trabalho.

O aterro sanitário é o método de disposição - particularmente de lixo domiciliar regido por critérios de engenharia e normas específicas que permitem a confinação segura em termos de controle de poluição ambiental e proteção à saúde pública. 
Os aterros sanitários têm apresentado limitações, pois a produção do lixo nos centros urbanos tem-se acentuado, devido ao crescimento das cidades. Associado a isto, as áreas destinadas à implantação destes aterros têm vida útil limitada, tornando-se cada vez mais difícil encontrar áreas próximas aos centros urbanos.

De uma maneira geral, a Figura 2.1 apresenta as partes físicas que compõem um aterro sanitário, que consistem em:

$\sqrt{ }$ Camadas de impermeabilização de fundo e nas laterais: Responsáveis pela fundação do aterro, com a função de evitar a contaminação do subsolo e de aqüíferos subjacentes pela migração dos poluentes.

$\sqrt{ }$ Camadas de cobertura final: Tem a função de minimizar a infiltração de águas pluviais, que podem causar aumento no volume do percolado, e consequentemente, do volume de líquido a ser tratado. Além de impedir que gases escapem para a atmosfera, e promover um melhor aspecto estético final.

$\sqrt{ }$ Drenagem pluvial e proteção superficial: Desvia o escoamento superficial das águas pluviais, de maneira que evite a infiltração para as camadas subjacentes.

$\checkmark$ Sistema de coleta de efluentes: Tem a função de coletar o chorume dos drenos e conduzi-lo até um reservatório para tratamento de líquidos.

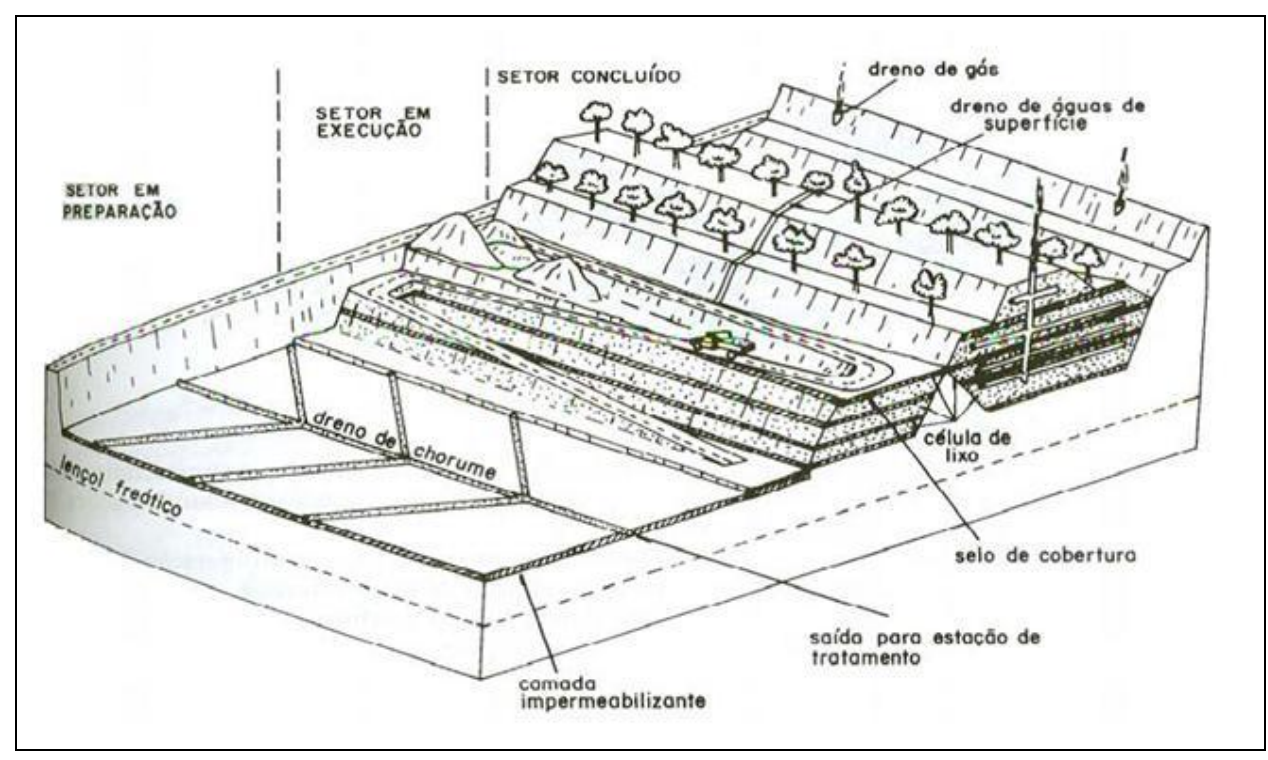

Figura 2.1 - Partes físicas principais que compõem um aterro sanitário (IPT, 1995). 
Em áreas destinadas à disposição frequentemente se utiliza o solo como material de impermeabilização de fundo dos aterros. Este material apresenta capacidade de atenuar e reter a maior parte dos resíduos. Porém, a geração e a composição dos resíduos tornaram-se, de tal forma, cada vez mais complexas que a capacidade de retenção do solo tem sido ultrapassada. Assim, apesar as águas subterrâneas serem mais protegidas que as águas superficiais, estas podem ser poluídas ou contaminadas quando os poluentes atravessam a camada não saturada do solo (Boscov, 1997).

Para distinguir a diferença entre os termos contaminação e poluição, Leite (1997) parte do seguinte princípio: uma situação onde a concentração do contaminante atinge níveis ameaçadores substitui o termo contaminante por poluente. Ou seja, os contaminantes são substâncias ou espécies "estranhas" ao sistema, causadoras ou não de danos às utilizações do meio contaminado pelo homem; e os poluentes são substâncias ou espécies que "julgam-se" prejudicial às utilizações do meio poluído pelo homem.

O impacto da instalação de uma área de disposição de resíduos na qualidade das águas subterrâneas depende de vários fatores, tais como: natureza do local, tipo do resíduo, hidrogeologia do local, presença do fluxo dominante e, sobretudo, a natureza da barreira que se destina, para limitar e controlar a migração do contaminante (Rowe, 1988). Segundo Boscov (1997), os processos de contaminação no solo ocorrem de forma lenta e freqüentemente sem conseqüências imediatas trágicas. Porém, quando ocorridos em longo prazo, podem ter efeitos sérios e irreversíveis.

O líquido que escoa através do aterro devido a disposição dos resíduos é conhecido como chorume. Alonso (2005) caracteriza o chorume como um líquido de alta demanda bioquímica de oxigênio (DBO) de cor negra e odor desagradável produzida pela decomposição de matéria orgânica em lixões e aterros sanitários. As espécies químicas que se destacam nessas fontes de contaminação são: os cloretos, os nitratos e os metais pesados; por estarem presentes na maioria dos contaminantes inorgânicos.

A legislação brasileira classifica os resíduos, quanto à periculosidade, em três categorias, classe I, II e III (ABNT, 1987). 
Resíduos de Classe I

Resíduos Perigosos: Podem apresentar riscos á saúde pública em função de suas propriedades físicas, químicas ou infecto-contagiosa, acentuando, de forma significativa, a mortalidade ou a incidência de doenças e/ou riscos ao meio ambiente, quando manuseados ou armazenados de forma inadequada; ou ainda apresentar características patogênicas de inflamabilidade, reatividade, corrosividade e toxidade.

\section{Resíduos de Classe II}

Resíduos Não Inertes: São todos os resíduos ou misturas de resíduos que não se enquadram nas classificações "Classe I - Perigosos" ou "Classe III - Inertes", e que podem apresentar propriedades como combustibilidade, biodegradabilidade ou solubilidade em água. Os resíduos domiciliares são classificados como classe II.

Resíduos de Classe III

Resíduos Inertes: São resíduos não perigosos, quando submetidos a um contato estático ou dinâmico com água destilada ou deionizada, à temperatura ambiente, não apresentam nenhum de seus constituintes solubilizados em concentrações superiores aos padrões de potabilidade da água; por exemplo, rochas, tijolos, vidros, certos plásticos e outros.

De acordo com o tipo de resíduo, os aterros sanitários são caracterizados como construções específicas para disposição de resíduos sólidos urbanos (RSU), e aterros industriais aqueles implantados somente para resíduos sólidos industriais (RSI). Os resíduos semi-sólidos ou lodos são dispostos em lagoas de deposição, ou seja, em bacias abertas circundadas com diques de contenção.

Os resíduos são colocados em camadas abaixo do nível da superfície original do terreno natural ou em pilhas, e cobertos de solo. Nas pilhas, os resíduos são dispostos sobre a superfície, com os taludes compactados ou não. Esta é a prática mais comum para resíduos com baixo teor de umidade ou que drenam rapidamente (Boscov, 1997). A separação da superfície do subsolo é dada pela implantação dos sistemas de revestimentos, utilizando-se as barreiras impermeabilizantes. Os aterros sanitários devem ser cobertos por revestimento superior, para evitar a infiltração de água e emissões gasosas. 
A literatura apresenta inúmeros fatores a serem considerados para a escolha do tipo de material a ser utilizado para a implantação de liners. Folkes (1962) determina os aspectos que tem grande influência na escolha do tipo de material, tais como: uso a que se destina; características do ambiente físico; natureza da matéria-prima; taxa de infiltração e vida útil do projeto. Além destes aspectos, Leite (2000) insere neste contexto outros fatores, como: características do projeto e características do material que será depositado.

Daniel (1993) discute em suas investigações sobre a maneira de como serão depositados os resíduos em relação ao nível da superfície do terreno. Quando dispostos acima da superfície, tem-se a vantagem de drenar o lixiviado por gravidade. E abaixo da superfície do terreno tem-se a vantagem de depositar um volume maior de resíduo numa determinada área, permitindo o uso do solo escavado para a cobertura final.

De acordo com Leite (1997), a barreira impermeável, conhecida também como Liner, é caracterizada por uma camada de baixa permeabilidade, construída de material natural, artificial ou pela combinação de ambos. Estas barreiras têm como objetivo evitar a percolação de fluidos. São aplicadas em diversos tipos de obras de engenharia, como os aterros sanitários e lagoas de tratamento de resíduos.

\subsection{Revestimento de fundo em aterros (Liners)}

Embora existam variações de exigências técnicas requeridas para a implantação de barreiras impermeabilizantes como revestimento de fundo Rowe et. al. (1995) recomendam alguns princípios fundamentais:

$\sqrt{ }$ Baixa condutividade hidráulica $(K)$, ou seja, deve ser no mínimo $10^{-9} \mathrm{~m} / \mathrm{s}$, e não deve apresentar fraturas na condição natural ou induzidas pelo efeito da compactação. Quando em contato com soluções químicas, o fluxo preferível deverá apresentar condutividade hidráulica de $10^{-10} \mathrm{~m} / \mathrm{s}$, e o transporte deve ser dominado pelo mecanismo da difusão;

$\sqrt{ }$ A baixa condutividade hidráulica está diretamente associada à presença dos argilominerais, portanto, deve estar presente no solo uma quantidade mínima de $15-20 \%$ de partículas menores que $2 \mu \mathrm{m}$, com índice de plasticidade menor que $7 \%$ e atividade coloidal maior que 0,3 . A capacidade de troca catiônica deve ser de $10 \mathrm{cmol} / \mathrm{dm}^{3}$; 
$\sqrt{ }$ A barreira argilosa deve ser compatível com o rejeito disposto, de forma que a condutividade hidráulica não sofra aumentos significantes;

$\sqrt{ }$ A espessura mínima de uma barreira argilosa compactada deve atender de 0,9 a 1,0 m. Entretanto, em alguns casos, dependendo do tipo de jurisdição, esta espessura pode ser reduzida para 0,6 m quando utilizada juntamente com geomembranas;

$\sqrt{ }$ Para a contenção de resíduos industriais tóxicos, a espessura mínima de uma barreira argilosa é de 3,0 a 4,0 m, embora algumas jurisdições exijam valores acima de $15 \mathrm{~m}$ ou sistemas de barreiras compostas múltiplas.

Os autores Daniel (1993) e Manassero et. al. (2000) comentam ainda que sistemas compostos podem oferecer vantagens em curto e longo prazo, como: baixa condutividade hidráulica global como resultado da atenuação dos defeitos locais, tanto da geomembrana como do solo compactado; minimização de problemas de trincas de secagem e fraturas. Além disso, o material geossintético retarda o contato entre o solo e o percolado, dando tempo para que o solo sofra adensamento sob o peso do resíduo, reduzindo ou evitando problemas de compatibilidade. Este material deve ter espessura mínima de 0,76 mm. Para resíduos não perigosos, as recomendações são similares, porém, a espessura mínima da camada de solo compactado é reduzida para $0,6 \mathrm{~m}$.

\subsubsection{Especificações técnicas para a impermeabilização de aterros}

Segundo Chui (1998, apud Ferrari, 2005), nos Estados Unidos e nos países europeus são disseminadas recomendações relativas a projetos de áreas para disposição de resíduos; dentre os requisitos básicos estão os sistemas de impermeabilização de fundo, os quais compreendem uma ou mais camadas de solo compactado.

As especificações internacionais diferem bastante quanto á espessura das camadas de impermeabilização, aceitabilidade de coeficientes de permeabilidade e presença ou não de geomembrana. A Figura 2.2 apresenta algumas configurações. 


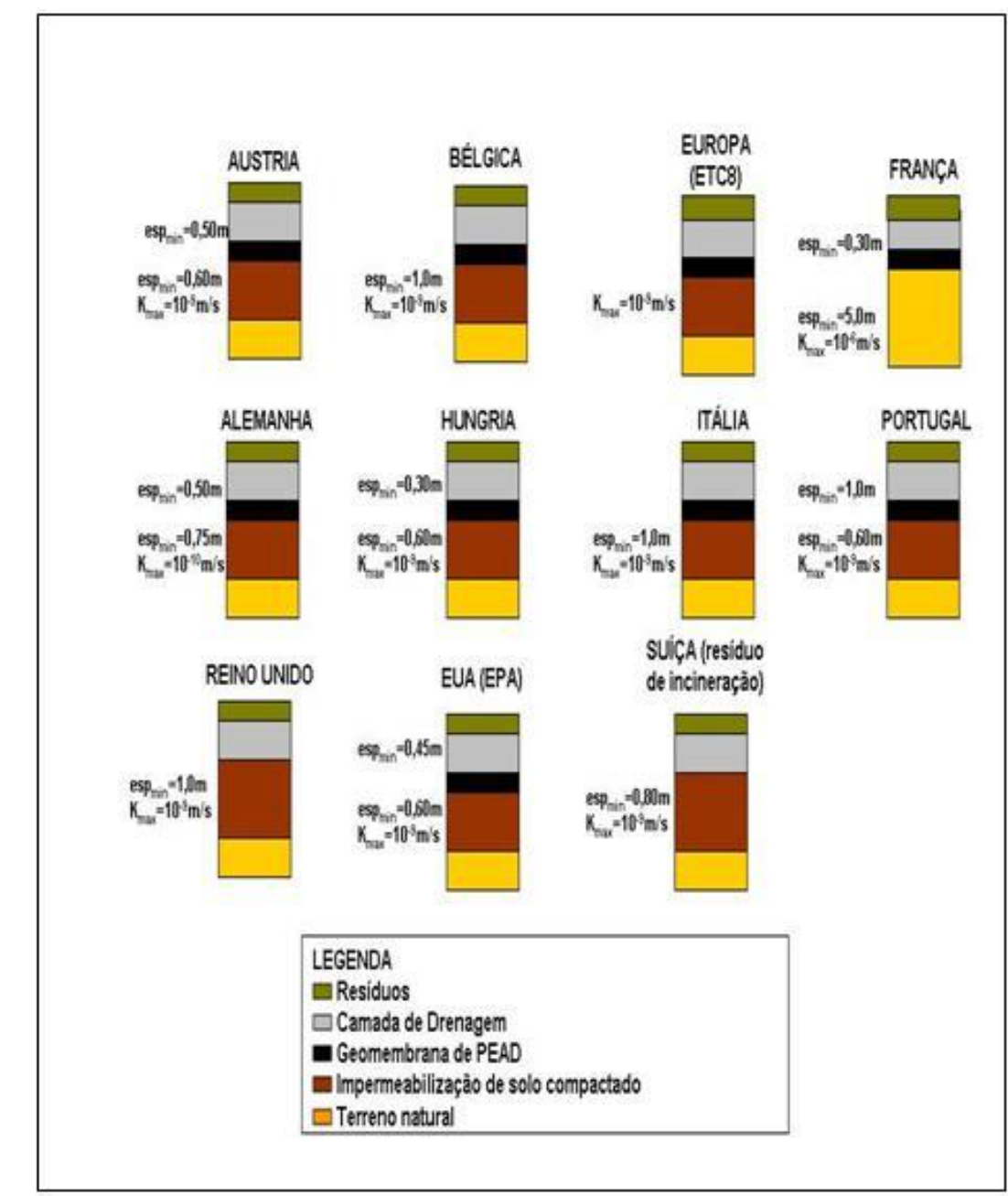

Figura 2.2 - Sistemas de impermeabilização inferior para aterros de RSU considerando diferentes regulamentações e recomendações (Ferrari, 2005 modificado de Manassero, 1997).

De acordo com as configurações apresentadas na Figura 2.2, percebe-se que a Itália considera no mínimo $10^{-8} \mathrm{~m} / \mathrm{s}$ o valor da condutividade hidráulica, com espessura mínima da de 1,0 m na camada de solo compactado. No caso da França, essa camada é dispensada desde que o terreno natural tenha espessura mínima de 5,0 m quando o solo estiver na condição não saturado. Já na condição de solo saturado os valores de condutividade hidráulica não devem exceder a $10^{-6} \mathrm{~m} / \mathrm{s}$. Apenas a Suíça e o Reino Unido dispensam a utilização de geomembrana de PEAD.

No Brasil são utilizados como métodos usuais para a disposição de resíduos sólidos os aterros sanitários, devido a pouca adoção de medidas preventivas. Portanto, nesta condição, o aterro é responsável por empregar todas as técnicas construtivas, desde o confinamento do resíduo, redução de volume depositado até a mitigação de impactos ambientais (PROSAB, 2006). 
A legislação brasileira não auxilia o suficiente os projetos e à concepção de tratamento nas fundações de barreiras impermeabilizantes. No Brasil, existem apenas algumas normas e regulamentações quanto à construção e projetos de aterros de resíduos industriais perigosos e resíduos sólidos urbanos. As regulamentações brasileiras (ABNT - NBR 10.157/87, 8.418/92, 8.419/92, 8.849/85) direcionam algumas questões básicas para o controle e a minimização de possíveis danos ambientais.

A Companhia de Tecnologia e de Saneamento Ambiental de São Paulo (CETESB, 1993), estipulou algumas exigências sobre o sistema de implantação das barreiras impermeabilizantes para aterros de disposição de resíduos sólidos urbanos. As exigências referem-se á profundidade de ocorrência do aqüífero, a condutividade hidráulica do material de fundação e as condições hidrogeológicas e climáticas do local. Nas Figuras 2.3 e 2.4 estão apresentadas diferentes situações indicando a necessidade ou não de impermeabilização do terreno natural.

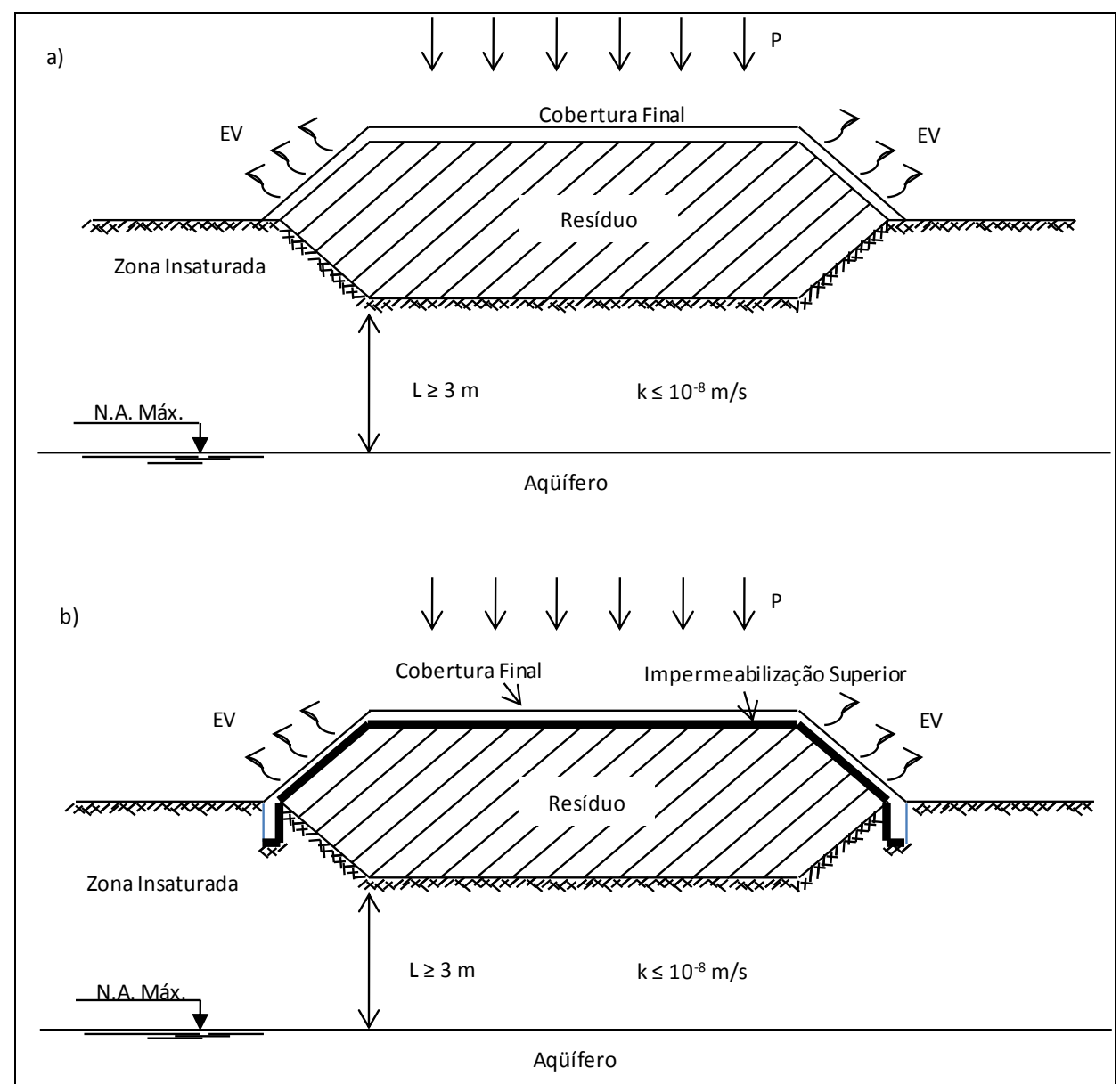

Figura 2.3 - Esquema de aterros de resíduos sólidos urbanos, sem impermeabilização na base (CETESB, 1993). a) Condições climáticas e hidrogeológicas favoráveis. b) Condições climáticas insatisfatórias e hidrogeológicas favoráveis. 
Para terrenos de fundação que apresentam condutividade hidráulica inferior a $10^{-8} \mathrm{~m} / \mathrm{s}$ e nível de água a uma profundidade igual ou superior a 3,0 m (Figura 2.3), não há necessidade de impermeabilização da superfície do terreno natural. Ainda assim, o que pode variar nesta recomendação é o sistema de impermeabilização de cobertura final, que depende do tipo de resíduo armazenado. Para subsolos mais permeáveis, com $K \leq 10^{-6} \mathrm{~m} / \mathrm{s}$ e a posição do nível d'água igual ou superior a 1,5 m, deve-se impermeabilizar a fundação do aterro (Figura 2.4).

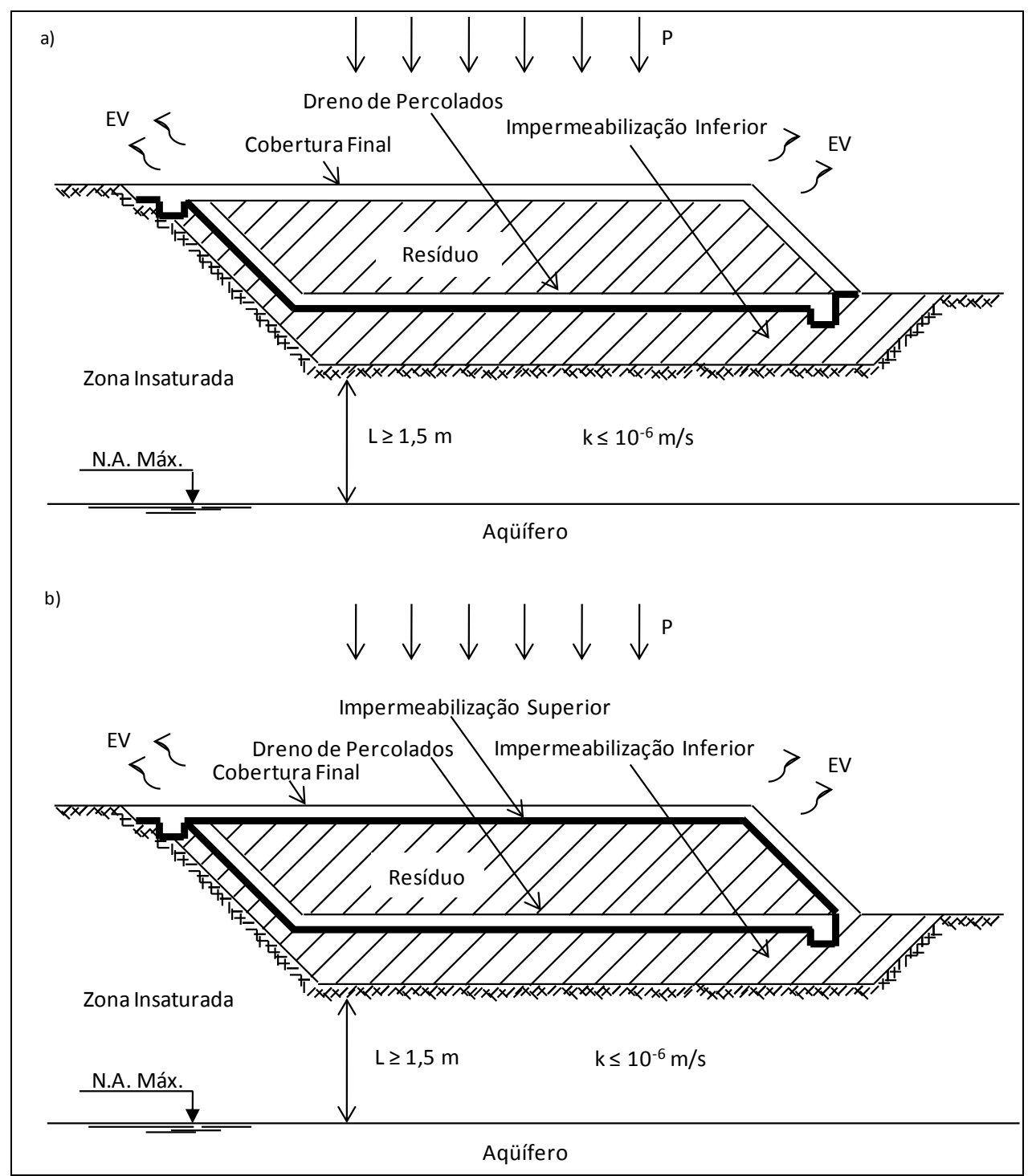

Figura 2.4 - Esquema de aterros de resíduos sólidos urbanos, com necessidade de impermeabilização na base (CETESB, 1993). a) Condições climáticas e hidrogeologia favoráveis. b) Condições climáticas e hidrogeologia insatisfatórias.

A CETESB (1993) recomenda para a disposição de resíduos perigosos (Figura 2.5) a combinação de solos argilosos compactados com geomembranas, atendendo ao critério de que o lençol freático seja posicionado a mais de $1,5 \mathrm{~m}$ de profundidade em relação à base do terreno e material de fundação de baixa condutividade hidráulica $\left(K \leq 5 \times 10^{-7} \mathrm{~m} / \mathrm{s}\right)$. 


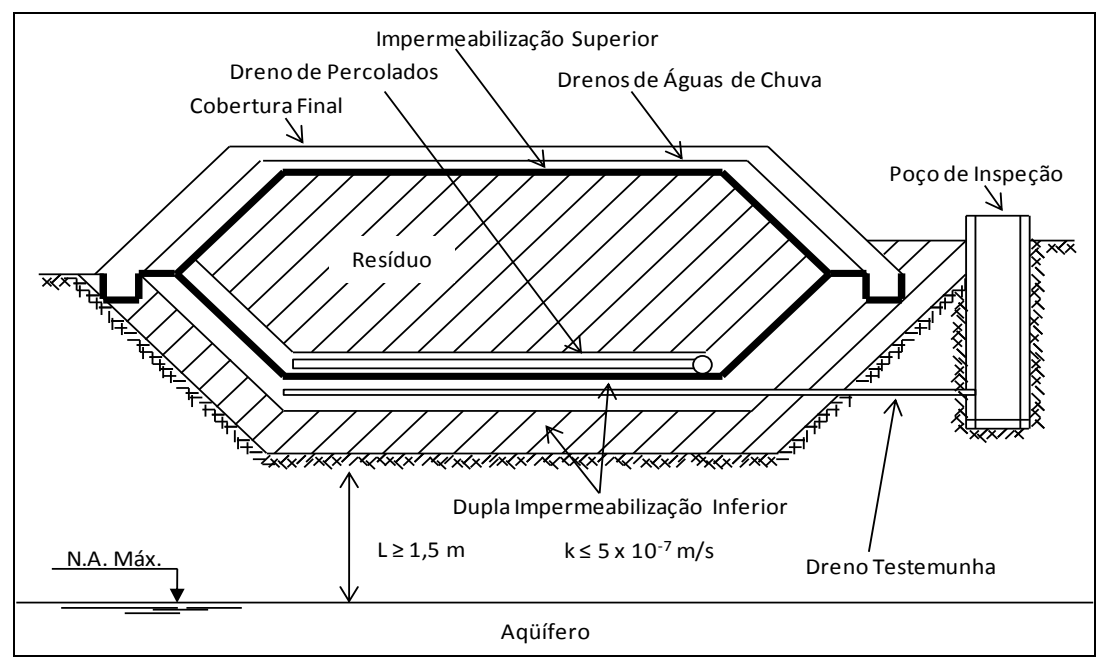

Figura 2.5 - Esquema de um aterro sanitário mostrando tipos de impermeabilizantes utilizados em resíduos perigosos (CETESB, 1993).

Segundo a norma da ABNT - NBR 13.896/97 “Aterros de Resíduos não Perigosos critérios para Projeto, Implantação e Operação", é necessário que o solo de vedação da base apresente-se com condutividade hidráulica inferior a $1 \times 10^{-8} \mathrm{~m} / \mathrm{s}$ e espessura mínima de $3,0 \mathrm{~m}$ (Basso, 2003).

\subsubsection{Tipos de Barreiras Argilosas}

Daniel (1993) define três tipos de liners de acordo com os materiais argilosos presentes na sua composição, classificando em: naturais, compactados e geossintéticos.

\subsubsection{Barreiras Argilosas Naturais}

São solos derivados de formações rochosas que apresentam naturalmente baixa condutividade hidráulica e alto teor de argila. O resíduo pode ser disposto diretamente sobre eles ou mesmo em escavações no seu interior. A condutividade hidráulica do material deve ser da ordem de $10^{-9} \mathrm{~m} / \mathrm{s}$, sendo livre de fraturas, juntas e fissuras.

\subsubsection{Barreiras Argilosas Compactadas}

São construídas por material compactado, predominantemente de solo argiloso, sedimentos inconsolidados ou mesmo argilas que receberam beneficiamento industrial. A fração fina do material (inferior a $0,074 \mathrm{~mm}$ ) possui as funções de impermeabilização e atenuação dos contaminantes, a fração granulométrica mais grossa funciona como barreira física ao rejeito disposto. 


\subsubsection{Geossintéticos argilosos (GCLs) e geomembranas}

Os GCLs são barreiras que apresentam baixa condutividade hidráulica. Consistem de uma camada desidratada de bentonita em pó, geralmente, montmorilonita $\mathrm{Na}^{+}$, aderida quimicamente ou mecanicamente à geotêxtil.

Este sistema de revestimento utilizando bentonita é chamado também de geocomposto bentonítico. A bentonita tem a capacidade de expansão quando em contato com líquidos. Quando hidratada sob confinamento, a bentonita expande-se formando uma camada de baixa condutividade hidráulica, que funciona como uma barreira de proteção hidráulica.

O comportamento do geocomposto bentonítico e da argila compactada, tanto no estado seco como no úmido, utilizados com função de barreira de baixa permeabilidade, deve ser tal, que após experimentar um ou mais ciclos de umedecimento e secagem sua permeabilidade mantenha-se inalterada. Tem sido utilizado em: aterros sanitários (revestimento da base e cobertura); valas de resíduos industriais; proteção secundária em armazenamento de combustíveis; reservatórios de água e lagoas ornamentais entre outros.

No Brasil, os GCLs são fabricados pela empresa OBER. Segundo o Boletim Técnico do fabricante, os geocompostos bentoníticos são constituídos de uma fina camada de bentonita sódica, envolvida por dois geotêxteis formando um único material. Como apresentado na Figura 2.6, essa configuração resulta em um produto uniforme que cumpre com as exigências técnicas das aplicações às quais é destinado.

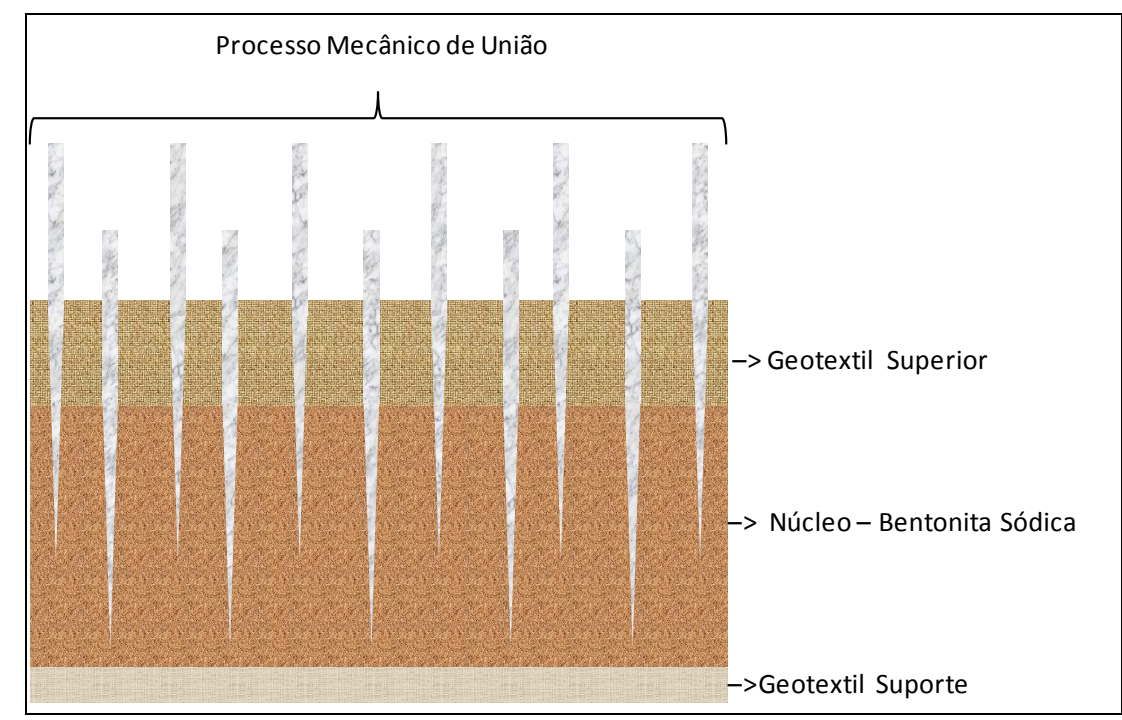

Figura 2.6 - Configuração do GCL FORTLINE fabricado pela OBER (modificado do Boletim Técnico Ober). 
A principal característica deste material está relacionada à propriedade da bentonita ser expansiva ao entrar em contato com o percolado. Esse processo de expansão ocorre no momento em que o material encontra-se confinado, gerando uma diminuição do índice de vazios do meio, garantindo baixa condutividade hidráulica $\left(\mathrm{K} \sim 10^{-11} \mathrm{~m} / \mathrm{s}\right)$.

Existem também outros materiais, como os geotêxteis, que são têxteis sintéticos aplicados geralmente em obras geotécnicas, trabalhando como: elemento de filtro em sistemas drenantes e gabiões, geomembrana de proteção, aterros sobre solos moles, reforço de aterros/contenção de taludes (solo reforçado), recapeamento asfáltico, reforço de pavimentos construídos sobre solos de baixa capacidade de suporte.

Suas principais funções são:

Filtração: Permite a livre passagem de fluidos (líquidos ou gases), retendo partículas sólidas;

Drenagem: Conduzir fluidos pelo seu corpo;

Separação: Evita a mistura de dois materiais de características diferentes;

Reforço: Atua como elemento de reforço de uma estrutura;

Proteção: Evitar danos a outro elemento;

Recapeamento asfáltico: redução de infiltração de água e reflexão de trincas em pavimentos deteriorados.

$\mathrm{Na}$ aplicação de geotêxteis para reforço de aterros ou contenção de taludes (solo reforçado), obtêm-se taludes mais íngremes ou até mesmo verticalizados, o que proporciona um importante ganho de área útil, seja em obras viárias, industriais ou comercial.

Sharma \& Lewis (1994) apresentam alguns sistemas de configuração de camadas de base aplicadas em aterros sanitários (Figura 2.7). 


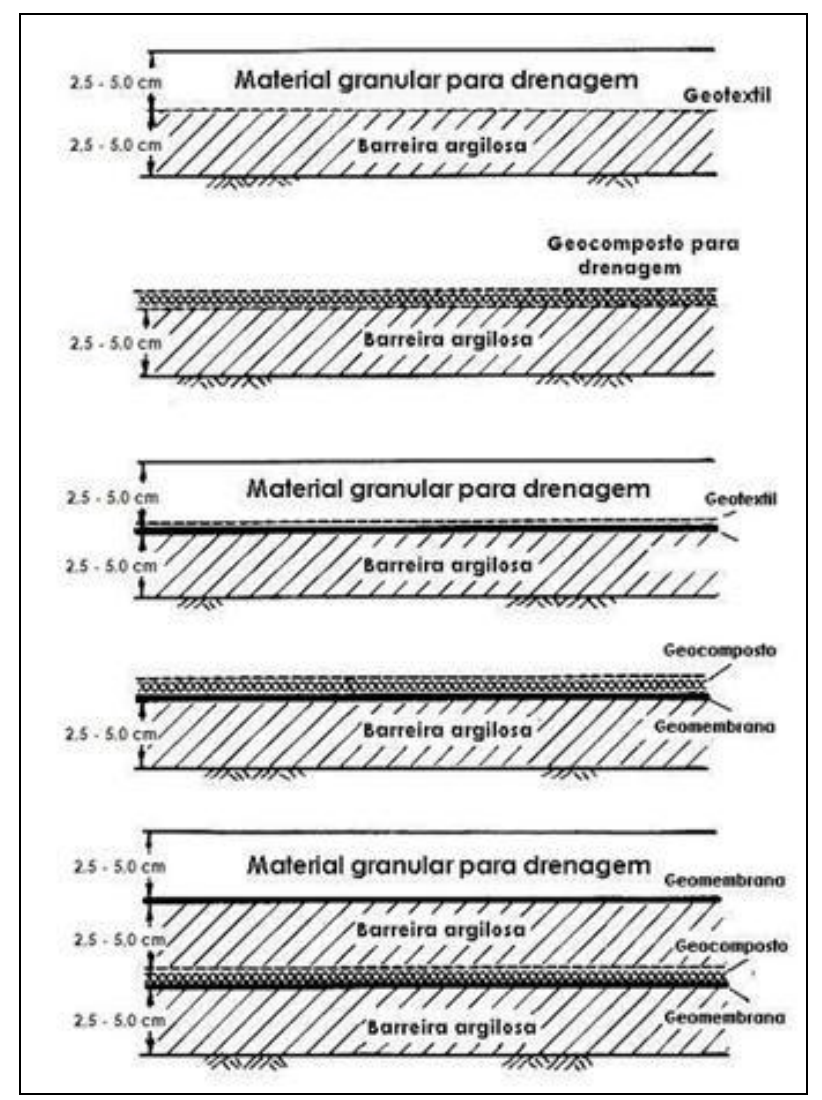

Figura 2.7 - Configuração para sistemas de base de aterros (Sharma \& Lewis, 1994).

A fim de melhorar as propriedades de materiais que podem ser empregados em barreiras impermeabilizantes, alguns autores estudam a utilização de misturas. Lukiantchuki (2007) estudou o comportamento da mistura de solo arenoso natural com bentonita, nos teores de $3 \%, 5 \%$ e $7 \%$. Os ensaios de condutividade hidráulica em permeâmetro de parede flexível apresentaram valores satisfatórios para as misturas com teores de 5\% e 7\% de bentonita. Os resultados viabilizam a adequação do material para o uso em liners. Alonso (2006) comenta que Mollamahmutoglu \& Yilmaz (2001) investigaram o potencial uso de cinza vulcânica em uma mistura de 5 a $30 \%$ de bentonita para o uso em barreiras impermeabilizantes. Os ensaios de condutividade hidráulica foram realizados com amostras compactadas no teor de umidade ótimo e massa específica seca máxima. Os resultados obtidos apresentaram valores de condutividade hidráulica inferior a $1 \times 10^{-9} \mathrm{~m} / \mathrm{s}$ para a mistura com $20 \%$ de bentonita, mostrando-se satisfatório. Outro aspecto observado foi o aumento da condutividade hidráulica com a percolação de soluções básicas $(20 \%$ de $\mathrm{NaOH})$ e moderadamente ácidas $(20 \%$ de $\mathrm{HCl})$. 
Folkes (1992) comparou resultados de laboratório e campo de condutividade hidráulica em vários tipos de materiais que podem ser utilizados como liner, como mostrado na Figura 2.8. Os resultados dos ensaios indicam que os tipos de liner analisados cumprem a exigência de baixos valores de condutividade hidráulica.

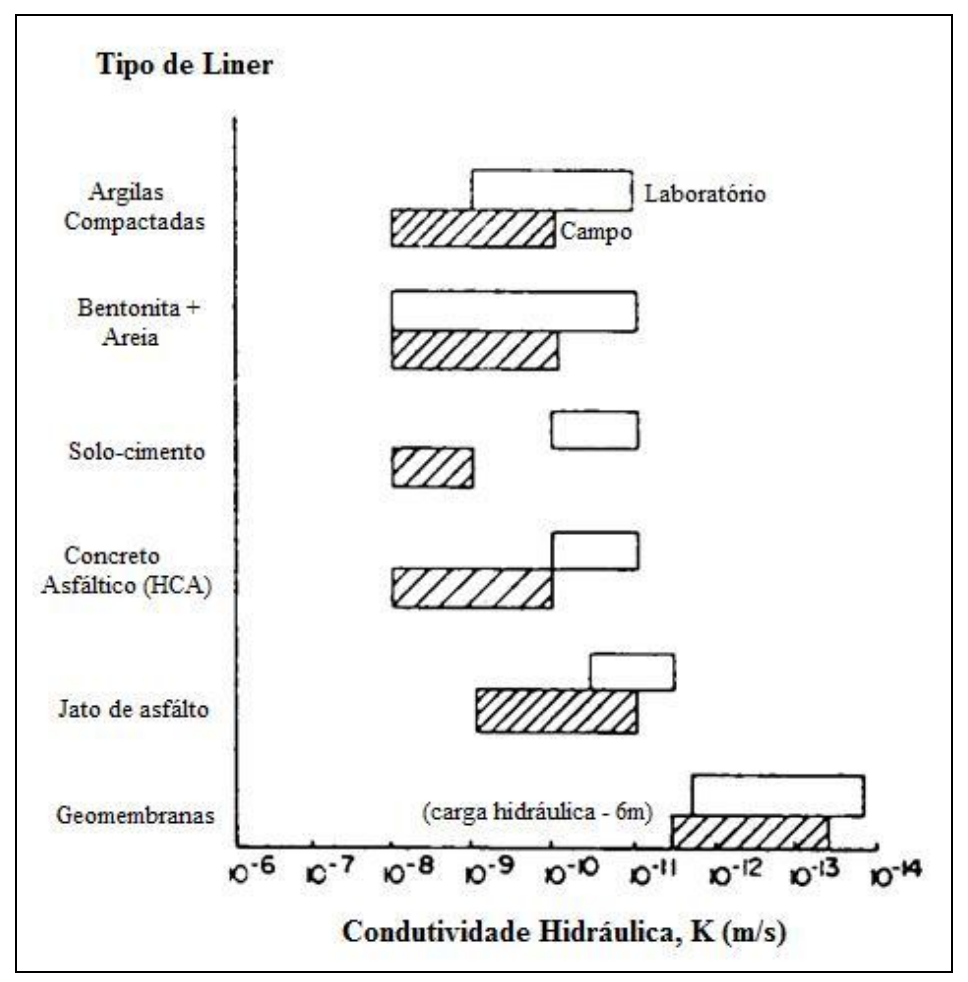

Figura 2.8 - Intervalos típicos de condutividade hidráulica obtidas em campo e laboratório de materiais que podem ser aplicados como liner (Folkes, 1992).

\subsubsection{Liners Compostos}

Um liner composto consiste na combinação de materiais argilosos naturais de baixa permeabilidade com um ou mais tipos de materiais geossintéticos. Esse sistema de revestimento torna-se mais eficaz do que qualquer liner de argila ou somente de materiais geossintéticos, por limitar a migração do percolado no subsolo (Hughes, 2005).

A eficácia da combinação desses materiais esta diretamente relacionada com a condutividade hidráulica, que pode ser afetada pela má eficiência do revestimento de fundo dos aterros. Portanto, a infiltração do percolado e o aumento da temperatura no interior do aterro provocam alterações das camadas de solo originando fissuramento das mesmas. Entretanto, a combinação de bentonita à camada pode acarretar na diminuição em várias ordens de grandeza no valor da condutividade hidráulica. 
Existem várias formas de combinação de liner utilizadas em aterros sanitários. Os liners duplos são constituídos de duas camadas simples, duas camadas duplas, ou uma camada simples combinada a uma camada dupla. Geralmente as configurações utilizadas aplicam solo argilosos compactados (CCL) combinados à geomembranas (GM), ou geocomposto bentonítico (GCL) combinado à GM. Esses sistemas funcionam por partes, onde a camada superior (primária) do revestimento funciona para coletar o percolado, enquanto que a camada inferior (secundária) do revestimento atua como um sistema de detecção de vazamentos, assim como, garante segurança para a camada primária.

Koerner (1999) apresenta três alternativas de barreiras: a primeira somente camada de argila, a segunda sendo uma camada de argila e uma de geomembrana e a terceira um GCL e uma geomembrana (Figura 2.9).

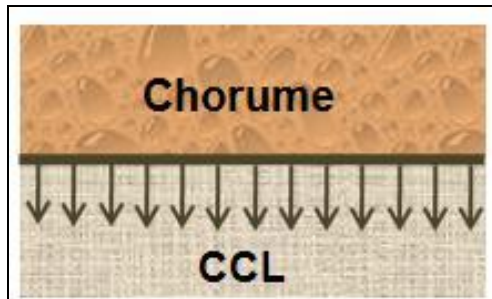

(a)

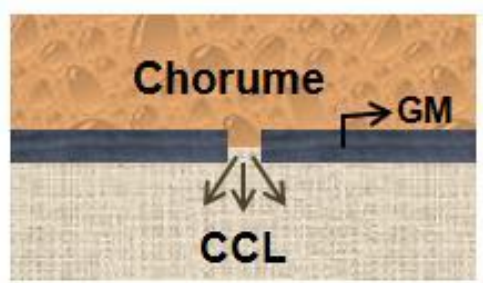

(b)

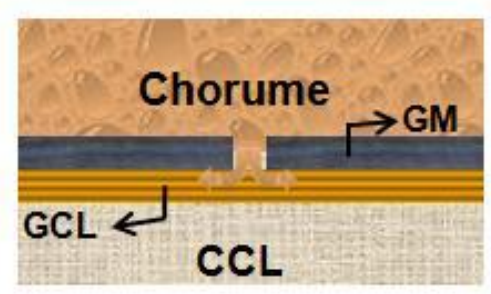

(c)

Figura 2.9 - (a) Barreira argilosa compactada; (b) Sistema composto de Geomembrana + argila compactada; (c) Sistema composto de Geomembrana + GCL + argila compactada (Koerner, 1999).

Em liners duplo, o GCL pode compor a camada revestimento primário (superior) com uma geomembrana, o revestimento secundário sendo constituído por uma geomembrana mais uma camada de argila compactada. Koerner (1999) comenta que a redução da percolação em obras executadas com a composição GM + GCL em relação a uma única GM ou a composição GM + argila compactada é significativa. No caso em que são instaladas somente geomembrana sobre a camada drenante, a ocorrência de furos direciona o percolado para o sistema drenante. Caso não exista o sistema drenante, possivelmente o solo de apoio da geomembrana será contaminado. No conjunto GM + GCL, o geocomposto bentonítico é instalado no estado seco, portanto absorve qualquer vazamento através de furos ou defeitos da GM.

Benson et. al. (2005) realizaram pesquisas em aterros de resíduos no estado de Wisconsin (EUA), cujo sistemas de impermeabilização é constituída por CCL e por sistemas 
compostos de CCL combinado à geomembrana. Foi analisada a percolação de soluções com concentração de diclorometano em 81 lisímetros sob o aterro. Os autores não observaram diferenças significativas entre os dois tipos de revestimentos analisados. Porém, relatam que o sistema composto possa apresentar melhor desempenho quando percolado com poluentes inorgânicos.

Rowe \& Fraser (1993) analisaram quatro configurações de liner composto com o objetivo de avaliar a vida útil, vazamento da geomembrana e a condutividade hidráulica do GCL. Para simular o percolado, utilizaram-se concentrações de cloreto e diclorometano. As configurações de liner estudadas consitiram em: camada simples de geomembrana acima de uma camada de argila; camada dupla de geomembrana acima da camada de argila; camada simples de geomembrana acima de um GCL; camada dupla de geomembrana acima de GCL. Os autores verificaram que a condutividade hidráulica não sofreu alterações significativas quando percoladas pelas soluções nas quatro configurações. Esta insensibilidade ocorre devido ao processo de migração ser predominantemente difusivo para as geomembranas enquanto intactas. Quando as mesma encontram-se com falhas, ou seja, furos, o processo de migração é dominado pela advecção. Desse modo, a instalação dos materiais é o fator preponderante para um bom desempenho hidráulico, uma vez em que, uma geomembrana bem instalada apresenta condutividade hidráulica muito baixa. Quanto ao GCL, a condutividade hidráulica torna-se o fator primordial para o controle do impacto. Os autores relatam também que as legilações internacionais exigem o prazo de vida útil do sistema de revestimento na avaliação do impacto potencial de um aterro sobre um aquífero subjacente. Sendo que a vida útil das geomembranas deve ser maior do que a do sistema de coleta de lixiviado.

As pesquisas realizadas em liner compostos geralmente são restritas a combinação de geossintéticos aplicados a camada argilosa compactada. $\mathrm{O}$ estudo de camadas de revestimento de fundos de aterros composta pela configuração analisada nesta pesquisa são escassas. Desse modo, esta pesquisa propõe um estudo inédito de liner composto por GCLs combinados a CCLs.

\subsubsection{Condutividade Hidráulica em Liners}

A condutividade hidráulica é o parâmetro responsável pelo fluxo de água no meio. De acordo com esse parâmetro escolhe-se o tipo de material a ser aplicado na construção das 
barreiras impermeabilizantes. Para isto, deve-se levar em consideração a compactação, as propriedades do solo e as características do fluido percolante, a fim de atingir reduzidas condutividades hidráulicas.

O método de compactação do solo tem como objetivo aumentar a resistência mecânica do material. No caso dos liners, a principal função da compactação é a redução da condutividade hidráulica. Isto ocorre através da remoldagem dos agregados de argila que diminuem os macroporos, principais responsáveis pelo fluxo de fluido no solo (Leite, 2001).

Quanto ao valor da condutividade hidráulica, alguns autores como Mitchell (1956) e Lambe (1962), recomendam que a camada de solo compactado da impermeabilização deve apresentar o valor de coeficiente no mínimo de $10^{-9} \mathrm{~m} / \mathrm{s}$.

A condutividade hidráulica de uma camada impermeabilizante deve ser determinada pelo coeficiente de permeabilidade $(K)$, de um meio poroso a um dado fluido, que pode ser definido como o valor da velocidade de fluxo média, quando a distância percorrida é igual á diferença de carga hidráulica dissipada durante o fluxo (gradiente unitário). Em solos saturados o estudo do fluxo baseia-se na Lei de Darcy (Pinto, 2002).

$$
K=Q . i . A
$$

Sendo:

$\mathrm{Q}=$ vazão percolada;

$\mathrm{K}=$ coeficiente de permeabilidade;

$\mathrm{i}$ = gradiente hidráulico;

$\mathrm{A}=$ área da seção transversal à direção do fluxo

O gradiente hidráulico é encontrado por meio da fórmula:

$$
i=\frac{\Delta H}{L}
$$

Sendo:

$\Delta \mathrm{H}=$ carga hidráulica dissipada na percolação

$\mathrm{L}=$ distância ao longo do qual a carga é dissipada. 
Basso (2003) comenta que experiências realizadas para reduzir a condutividade hidráulica em solo arenoso acrescidos de quantidade de solos finos mostraram-se satisfatórias, pois os finos ocupam os espaços anteriormente vazios, reduzindo o índice de vazios.

Os principais fatores que influenciam esse fator são: a estrutura, a composição mineralógica, o grau de saturação e o índice de vazios do meio poroso e as características do fluido, sendo a estrutura do solo o fator predominante (Lambe, 1958).

\subsubsection{Fatores que afetam a condutividade hidráulica}

Vários fatores interferem na condutividade hidráulica, sendo estes inerentes ao solo. Porém, analisá-los separadamente é uma tarefa difícil, uma vez em que estão diretamente relacionados. O que pretende-se esclarecer são as características mais importantes de cada fator.

Os parâmetros geotécnicos compreendidos entre as propriedades de solos argilosos, a compactação, e as características do fluido percolante, devem ser os principais fatores envolvidos quando se deseja atingir valores reduzidos de condutividade hidráulica.

Um aspecto relacionado à matriz do solo é a composição mineralógica e química do material. Solos argilosos possuem em sua composição argilominerais que tem grande influência na condutividade hidráulica. Isto se deve á variações nas suas propriedades, devido à presença dos cátions trocáveis e das substituições isomórficas. Mesri \& Olson (1971) realizaram um estudo com argilominerais do grupo da esmectita, ilita e caulinita, a fim de avaliar o comportamento hidráulico destas argilas. A Tabela 2.1 apresenta os resultados obtidos. Os autores concluíram que a condutividade hidráulica diminui à medida que o índice de plasticidade aumenta.

Tabela 2.1 - Condutividade hidráulica dos argilominerais (Mesri \& Olson, 1971).

\begin{tabular}{ccc}
\hline Argilomineral & Índice de Plasticidade (\%) & Condutividade Hidráulica (m/s) \\
\hline Caulinita & 20 & $1,5 \times 10^{-8}$ \\
Ilita & 60 & $2 \times 10^{-11}$ \\
Montmorilonita & 500 & $1 \times 10^{-13}$ \\
\hline
\end{tabular}


Massad (2003) comenta que qualquer redução, mais ou menos rápida, do índice de vazios de um solo, por meios mecânicos, caracteriza um processo de compactação. Essa redução ocorre em face da expulsão ou compressão do ar dos vazios dos poros.

Pinto (2002) avalia que os valores de condutividade hidráulica são tanto menores quanto menores os vazios nos solos (Tabela 2.2). Porém, estes valores representam só uma ordem de grandeza e o que determina os valores de condutividade hidráulica são os finos do solo e não a predominância de tamanho dos grãos.

Tabela 2.2 - Valores típicos de condutividade hidráulica em relação ao tipo de solo (Pinto, 2002).

\begin{tabular}{cc}
\hline Tipo de solo & Condutividade Hidráulica $(\mathbf{m} / \mathbf{s})$ \\
\hline Argilas & $<10^{-9}$ \\
Siltes & $10^{-6}$ a $10^{-9}$ \\
Areias argilosas & $10^{-7}$ \\
Areias finas & $10^{-5}$ \\
Areias médias & $10^{-4}$ \\
Areias grossas & $10^{-3}$ \\
\hline
\end{tabular}

Ralph Proctor (1933, apud Massad, 2003) estabeleceu os princípios básicos da técnica e controle de compactação. Desenvolveu uma metodologia para determinação do ponto ótimo de compactação dos solos (ponto de máxima compactação). Segundo o Engenheiro americano, "a densidade que um solo atinge quando compactado sob uma dada energia de compactação, depende da umidade do solo no momento da compactação", sendo que o mesmo desenvolveu um ensaio dinâmico para a determinação experimental da curva de compactação (peso específico seco versus teor de umidade). A partir da curva de compactação determina-se o teor de umidade ótimo $\left(\mathrm{w}_{\mathrm{ot}}\right)$ e peso específico seco máximo $\left(\gamma_{\mathrm{smáx}}\right)$ (Figura 2.10).

Segundo Lambe \& Whitman (1970, apud Pinto, 2002), a estrutura do solo no ramo seco encontra-se floculada, com tamanhos médios de vazios facilitando a percolação da água proporcionando maior coeficiente de permeabilidade. Já no ramo úmido, o solo apresenta estrutura dispersa, dificultando o fluxo de água e conseqüentemente menor valor de condutividade hidráulica (Figura 2.10). 


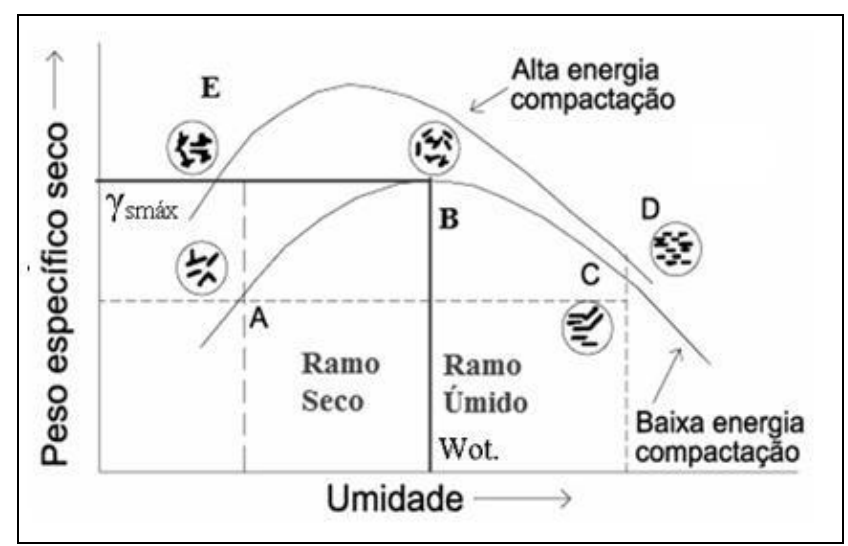

Figura 2.10 - Alteração da estrutura do solo devido à energia e umidade de compactação, apresentado por Lambe (modificado de Pinto, 2002).

A energia de compactação é outro fator que está diretamente relacionado à compactação. Mitchell et.al.(1965) realizaram um estudo para analisar o efeito da energia e metodologia de compactação na condutividade hidráulica em corpos-de-prova saturados. Os autores detectaram que o aumento na energia ocasiona redução na condutividade hidráulica. A Figura 2.11 apresenta os resultados obtidos de condutividade hidráulica e massa específica aparente seca em relação ao teor de umidade para as diferentes energias utilizadas.

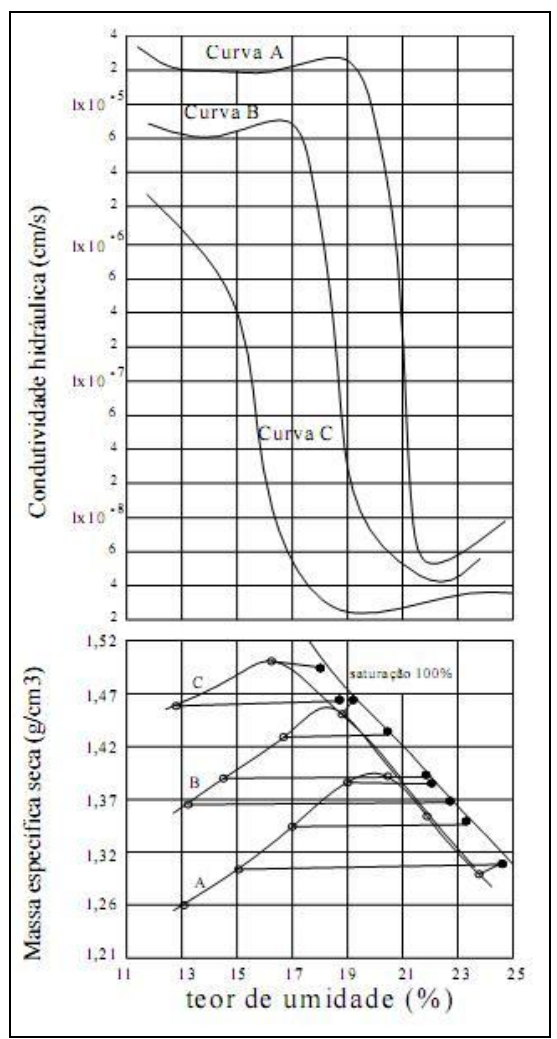

Figura 2.11 - Variação da condutividade hidráulica devido ao aumento da energia de compactação (Mitchell et. al.,1965). 
Mitchell et. al. (1965) analisaram também a influência da estrutura do solo e do método de compactação na condutividade hidráulica de amostras de argilas siltosas. As amostras com limite de liquidez de $37 \%$ e limite de plasticidade de $23 \%$, foram compactadas estaticamente com intervalos variados de teor de umidade moldado e massa específica aparente seca constante. Os autores verificaram que ocorreu uma variação na condutividade hidráulica de maneira que os pontos moldados com menor teor de umidade apresentaram valores da ordem de $10^{-6} \mathrm{~cm} / \mathrm{s}$. E os pontos moldados com teores de umidade acima do ótimo apresentaram um decréscimo na condutividade hidráulica com valores da ordem de $10^{-8} \mathrm{~cm} / \mathrm{s}$ (Figura 2.12).

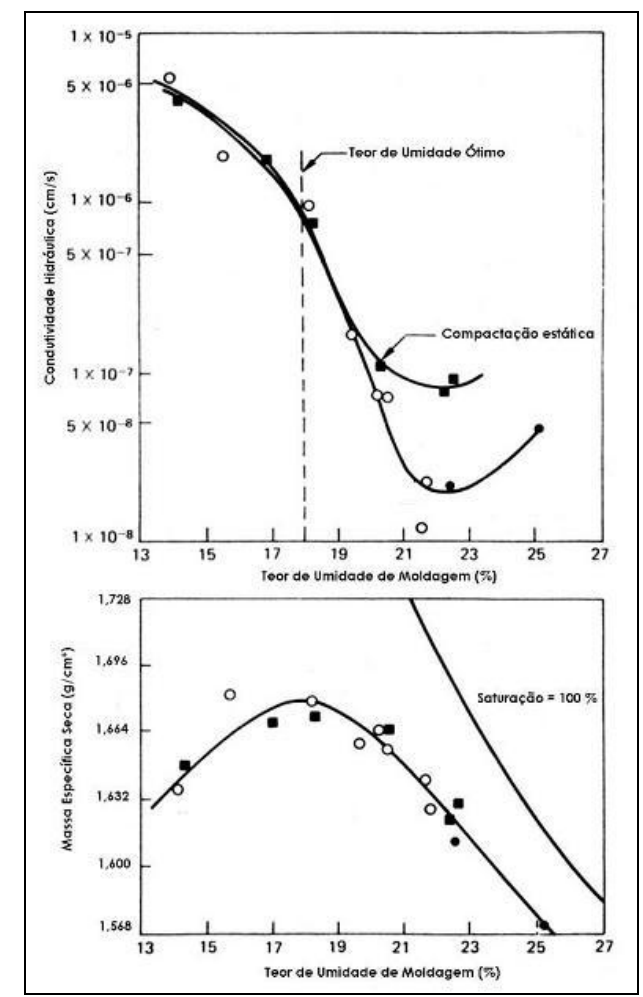

Figura 2.12 - Variação da condutividade hidráulica e massa específica seca em função do teor de umidade (Mitchell et. al., 1965).

A relação existente entre o teor de umidade e o arranjo das partículas é apresentada por Olsen (1962). O autor sugere que a condutividade hidráulica de um solo é menor quando as amostras são compactadas no ramo úmido na condição estrutural de torrões. O fato de serem remoldados com maior facilidade por encontrarem-se úmidos e compressíveis resultam em menores índices de vazios. Desse modo, a maior parte do fluxo de água em solos argilosos compactados ocorre através de grandes poros espaçados, localizados entre os torrões de argila do que entre as partículas de argilas dentro dos torrões (Figura 2.13). 


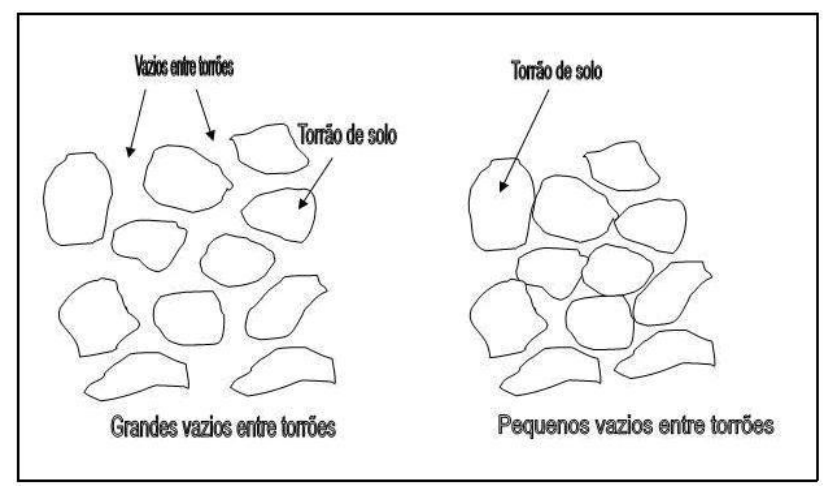

Figura 2.13 - Modelo dos torrões de Olsen (1962, modificado de Daniel \& Benson, 1990).

Para atingir um valor de condutividade hidráulica adequado, devem ser considerados intervalos de valores de teor de umidade $(w)$, massa específica aparente seca $\left(\rho_{d}\right)$ e energia de compactação. De acordo com Daniel e Benson (1990), a relação entre estes parâmetros baseia-se numa zona admissível em que os intervalos de valores situam-se dentro de um limite aceitável para construção de barreiras impermeabilizantes.

Esta zona admissível foi determinada através de critérios da prática de construção de base de estradas, barragens de terra e alguns tipos de aterros, a fim de atender os requisitos necessários quanto à resistência ao cisalhamento, compressibilidade e condutividade hidráulica de barreiras impermeáveis (Figura 2.14).

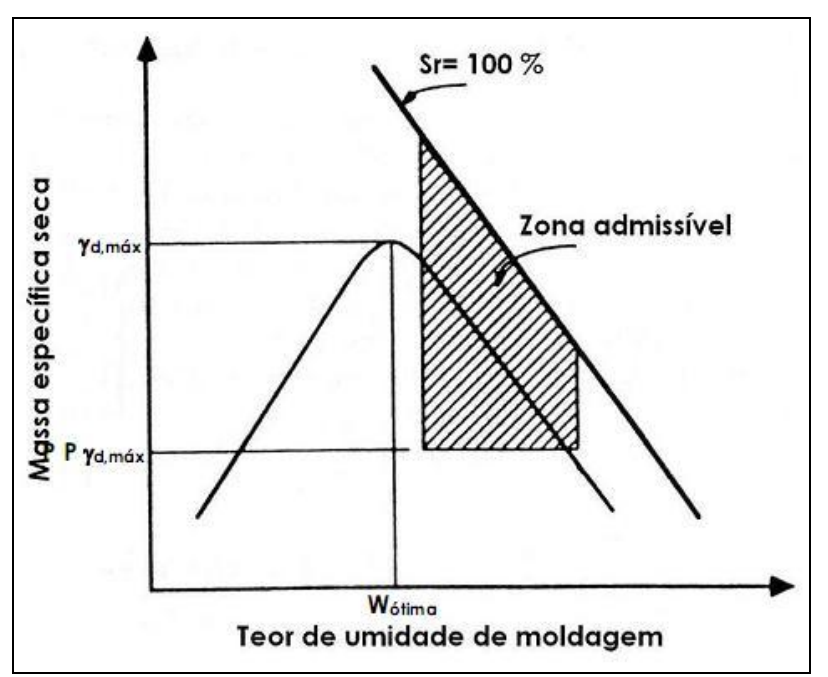

Figura 2.14 - Metodologia para determinar a zona adequada em termos de teor de umidade $\left(\mathrm{w}_{\mathrm{ot}}\right)$, massa específica seca $\left(\rho_{\mathrm{d}}\right)$ e condutividade hidráulica $(\mathrm{K})$ (Daniel \& Benson, 1990).

Para a metodologia de Benson \& Daniel (1990), foram utilizados dados de Mitchell et. al. (1965) e Boutwell \& Hedges (1989). Na investigação, os autores propuseram 
procedimentos de análise para determinar a zona admissível, incluindo os ensaios de permeabilidade. Desta maneira, ficaram estabelecidos os caminhos para alcançar pares de umidade e massa específica aparente seca objetivando baixos valores de condutividade hidráulica. As recomendações abordam:

i. Realizar ensaios de compactação nas energias Proctor reduzido, normal e modificado, com uma série de 5 a 6 corpos de prova para cada tipo de energia (Figura 2.15);

ii. Determinar os valores de condutividade hidráulica e monitorar a condição de saturação da amostra. O resultado obtido deve ser plotado em um gráfico de condutividade hidráulica em função do teor de umidade (Figura 2.15);

iii. Plotar com símbolo diferente dos demais as amostras que apresentarem valores de condutividade hidráulica igual ou inferior a $1 \times 10^{-7} \mathrm{~cm} / \mathrm{s}$. Portanto, a zona admissível é determinada através dos valores de condutividade hidráulica aceitáveis $\left(\geq 10^{-9} \mathrm{~m} / \mathrm{s}\right)$ (Figura 2.15);

iv. A zona admissível deve ser modificada considerando outros parâmetros, como: resistência ao cisalhamento, atrito interfacial com geomembrana, considerações de umedecimento e secagem, e interesses construtivos e práticas locais (Figura 2.16). 


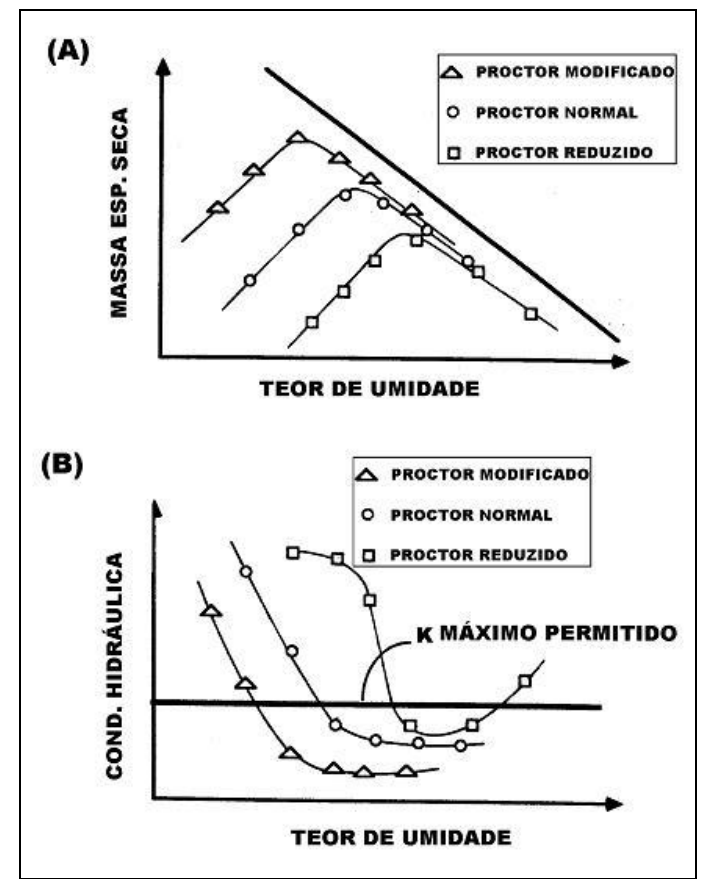

Figura 2.15 - Metodologia para determinar a zona admissível: (a) curva de compactação para as três energias; (b) resultados de condutividade hidráulica em função do teor de umidade (Benson \& Daniel, 1990).

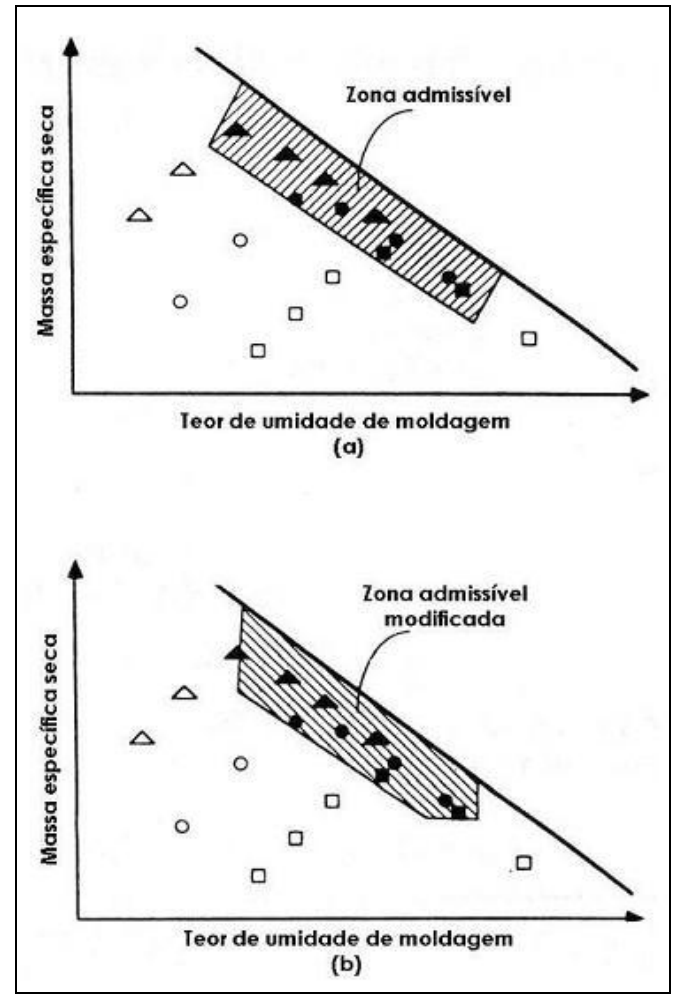

Figura 2.16 - Metodologia para determinar a zona admissível: (a) replotagem da curva de compactação com valores de condutividade hidráulica aceitáveis; (b) modificação da zona admissível de acordo com os fatores preponderantes (Benson \& Daniel, 1990). 
Além disso, deve-se levar em consideração o grau de saturação inicial, pois este é o parâmetro utilizado para a localização de diferentes combinações de teor de umidade e peso específico seco relativo ao teor de umidade ótimo, independente da energia de compactação. A permeabilidade tende a decrescer com o aumento do grau de saturação, ou seja, maior grau de saturação significa aumento de energia. Porém, aumentos na saturação inicial, não necessariamente resultam em diminuição da permeabilidade. Se o teor de umidade estiver muito acima do ótimo, a condutividade hidráulica pode aumentar enquanto a saturação permanece constante (Boscov, 1997).

De acordo com Mitchell (1993), é importante considerar que o gradiente hidráulico, a composição química do fluido de percolação, o grau de saturação da amostra e a pressão confinante influenciam na condutividade hidráulica da amostra de solo ensaiado em laboratório. Ferrari (2005) apresenta os valores de gradientes hidráulicos em função da condutividade hidráulica recomendados pela ASTM (1990) conforme a Tabela 2.3.

Tabela 2.3 - Gradiente hidráulico recomendado (ASTM D5084-90).

\begin{tabular}{cc}
\hline Coeficiente de permeabilidade $(\mathrm{m} / \mathbf{s})$ & Gradiente hidráulico \\
\hline $1 \times 10^{-5}$ até $10^{-6}$ & 2 \\
$1 \times 10^{-6}$ até $10^{-7}$ & 5 \\
$1 \times 10^{-7}$ até $10^{-8}$ & 10 \\
$1 \times 10^{-8}$ até $10^{-9}$ & 20 \\
Menor que $1 \times 10^{-9}$ & 30 \\
\hline
\end{tabular}

As propriedades dos líquidos percolantes nas barreiras de solo compactadas podem influenciar a condutividade hidráulica. As mais relevantes são: viscosidade do fluido e temperatura, além de suas propriedades químicas. Em materiais argilosos, outros fatores como as interações físico-químicas, podem ter influência na condutividade hidráulica, como: constante dielétrica, troca iônica e concentração de cátions. As propriedades de densidade e viscosidade afetam a condutividade hidráulica de maneira que o movimento do fluido através do solo devido à gravidade é maior de acordo com o aumento da densidade. O fluido tem velocidades menores, à medida que a viscosidade aumenta, ocasionando reduções na condutividade hidráulica, pois aumenta dificuldade de percolação através do meio poroso. Shackelford (1994) comenta a respeito das características químicas do percolado que podem ocorrer vários efeitos do fluido ao entrar em contato com o solo, como: floculação da argila, 
dissolução de argilominerais, entre outros, que podem aumentar a condutividade hidráulica. Segundo Daniel (1984), o contato prolongado do material utilizado com o liner com ácidos fortes, solventes orgânicos ou químicos cáusticos geralmente aumentam as taxas de infiltração.

Outros aspectos devem ser considerados também como fatores que influenciam na condutividade hidráulica, como: índice de vazios, arranjo das partículas, contração e expansibilidade e conteúdo salino.

\subsection{Mecanismos de transporte}

Sabe-se que nenhum material utilizado para a implantação de um liner é totalmente impermeável. Além de investigar as propriedades hidráulicas e mecânicas destes materiais quando em contato com a água, é necessário avaliar o comportamento quando permeados com soluções químicas contidas nos contaminantes.

Portanto, quando se depara com projetos de aterros sanitários que envolvem estimar o impacto que a liberação dos contaminantes ocasiona ao ambiente, torna-se imprescindível o conhecimento dos mecanismos e parâmetros de transporte de contaminantes envolvidos.

Os processos que permitem o deslocamento do fluxo são regidos pela advecção e dispersão hidrodinâmica (compreendendo a dispersão mecânica e difusão iônica), ou seja, são mecanismos de migração. Já os que retardam, ou desaceleram, são regidos pela adsorção, precipitação e complexação, responsáveis pela interação solo/contaminante, chamados de mecanismos de atenuação.

De acordo com Jesus (2004), o processo de migração e retenção de poluentes no solo é influenciado por alguns fatores relacionados com o fluido percolante, com o próprio solo, e com as condições ambientais: o tipo de solo, a mineralogia, a capacidade de troca de cátions (CTC), as espécies de cátions adsorvidos, a velocidade de percolação, o teor de matéria orgânica, a concentração do contaminante, a presença de outras substâncias na solução percolante, condições hidrogeológicas, temperatura e o $\mathrm{pH}$ do meio.

Estes processos mostraram em experiências, muitas vezes, que atuam de forma simultânea, ora predominando um, ora predominando outro, a depender das condições físicas e físico-químicas presentes (Leite, 1997). 
Este trabalho restringe-se aos contaminantes inorgânicos, constituídos pelo soluto (substâncias sólidas, moléculas e íons) e pelo solvente (água). Será apresentada somente a revisão dos mecanismos físicos e químicos que governam as substâncias solúveis em meios porosos.

\subsection{Advecção}

É o transporte de massa, ou o movimento de soluto dissolvido. Este movimento é dado pela direção e taxa de transporte coincidentes com a da água. A velocidade de transporte é igual à velocidade linear da água (Rowe, 2000). A velocidade de percolação, $\bar{v}$, pode ser descrita então pela Lei de Darcy:

$$
\begin{gathered}
\bar{v}=\frac{Q}{n} \\
Q=K . i . A
\end{gathered}
$$

Sendo:

$Q=$ é a vazão específica

$n=$ porosidade

$K=$ condutividade hidráulica

$i=$ gradiente hidráulico

Pode-se dizer então que o fluxo unidimensional de massa de uma espécie química por advecção através de uma área seccional unitária em uma unidade de tempo $\left(F_{A}\right)$ pode ser expresso por (Shackelford, 1993):

$$
F_{A}=V \cdot C=K \cdot i \cdot A=n \cdot \bar{v} \cdot C
$$

Sendo:

$F_{A}=$ fluxo do soluto por advecção

$C=$ concentração do soluto na fase líquida

$\bar{v}=$ velocidade de infiltração do soluto 
Oliveira (2002) comenta que a condutividade hidráulica é um parâmetro de extrema importância no que se refere ao transporte de contaminantes, pois oferece a maior ou menor resistência do meio à percolação de água e, consequentemente, aos contaminantes dissolvidos. Basso (2003) relata neste mesmo contexto que todos os fatores que influenciam na condutividade hidráulica irão interferir da mesma forma no processo advectivo.

\subsection{Dispersão hidrodinâmica}

É o espalhamento de massa em velocidades e direções diferentes do sentido do movimento do fluido, ocupando área maior do que no processo advectivo (Rowe, 2000). Os mecanismos principais deste espalhamento são: a dispersão mecânica e a difusão molecular e, portanto, o coeficiente de dispersão hidrodinâmica deve levar em consideração a soma desses dois mecanismos:

$$
D_{h}=D_{m}+D^{*}
$$

Sendo:

$D_{m}=$ é o coeficiente de dispersão mecânica

$D^{*}=$ é o coeficiente difusão molecular efetiva

A Figura 2.17 ilustra os mecanismos da dispersão hidrodinâmica em escala microscópica. Observa-se a velocidade diferencial do fluido nos canais dos poros causada pelo atrito do fluido com as partículas, assim como os caminhos tortuosos pelo qual a solução percorre. Ilustra também a contaminação por difusão molecular, que atua em função de gradientes de concentração.

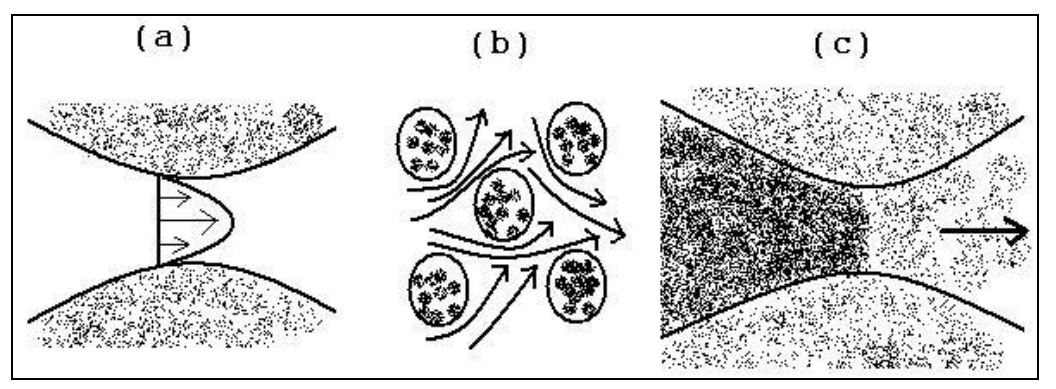

Figura 2.17 - Mecanismos da dispersão hidrodinâmica: (a) velocidade diferencial da solução interporos; (b) caminhos do fluxo tortuoso; e (c) mecanismo da difusão molecular atuando nos canais dos poros (Modificado de Freeze \& Cherry, 1979). 
De acordo com Freeze \& Cherry (1979), a Figura 2.18 ilustra o significado físico da dispersão em um experimento clássico de forma unidimensional. Neste experimento, o soluto não reativo em concentração inicial $\mathrm{C}_{0}$ é introduzido na parte superior da coluna sob regime de fluxo permanente em uma amostra de solo homogênea e saturada, como mostra a Figura 2.18 (a). Para efeito ilustrativo, assume-se que a concentração do soluto antes de ser introduzida seja zero. A concentração na coluna é uma concentração relativa, definida como $\mathrm{C} / \mathrm{C}_{0}$, onde $\mathrm{C}$ é a concentração efluente e $\mathrm{C}_{0}$ a concentração influente.

Na Figura 2.18 (b) a concentração da solução no instante $t_{0}$ ocupa uma área separada da água, enquanto que num segundo instante, esta região se transforma em região de transição, onde ocorre a primeira aparição. Deste ponto em diante a concentração varia da concentração inicial da solução $\mathrm{C}_{0}$ (Figura 2.18 (c)).

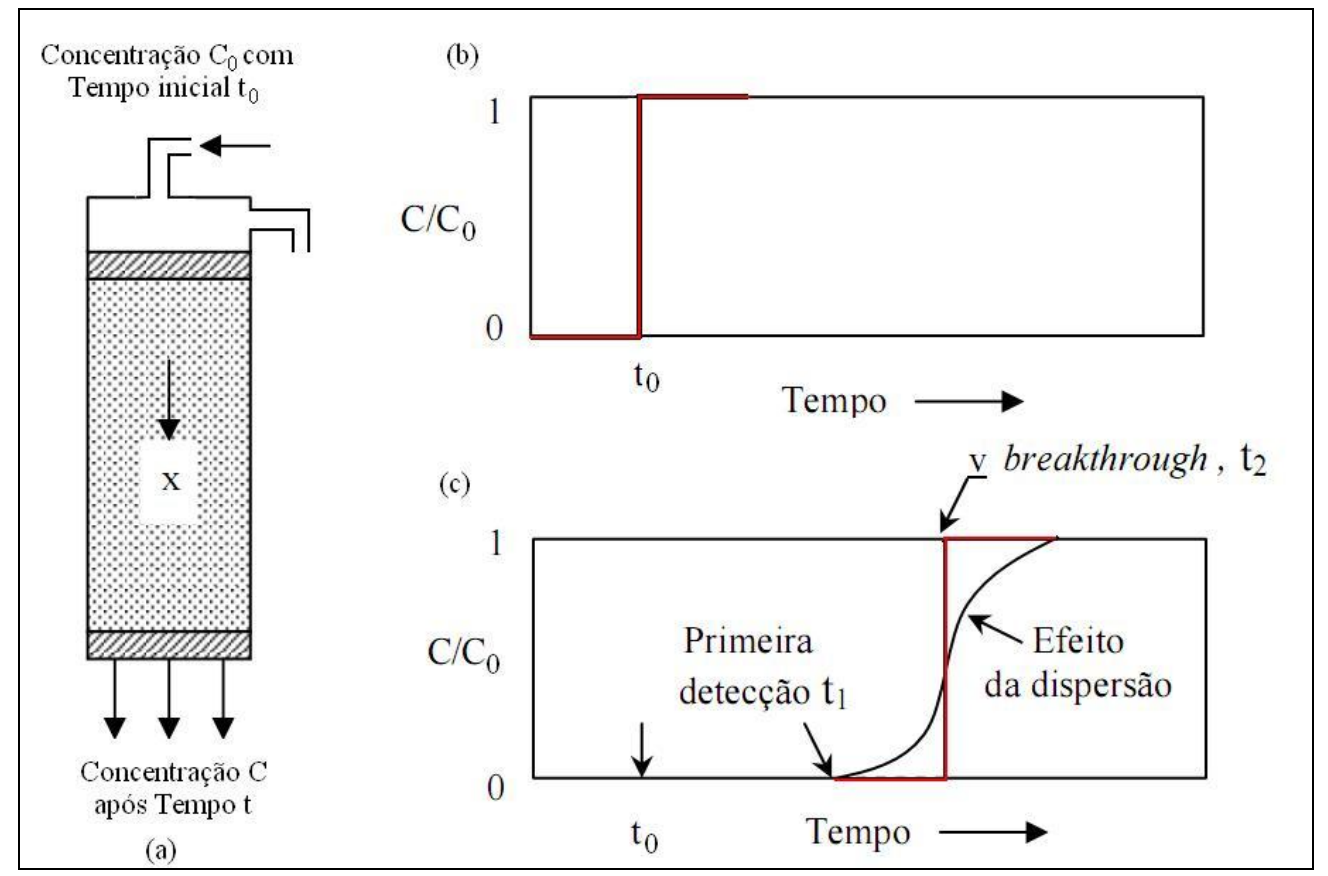

Figura 2.18 - Dispersão longitudinal de um soluto através de uma coluna de solo: (a) coluna com fluxo permanente e fonte contínua; (b) interface entre as concentrações no instante t0; (c) concentração relativa do soluto no efluente da coluna (adaptado de Freeze \& Cherry, 1979).

De acordo com Silva et. al. (2004) os fenômenos da difusão e dispersão hidrodinâmica uniformizam as concentrações dos solutos, sendo a difusão causada por um gradiente de potencial químico, resultando na migração do soluto de regiões de maior concentração para as de menor concentração. Os autores cometam ainda que este fato possa explicar casos, nos 
quais, em meios onde a condutividade hidráulica é muito baixa, a difusão possa vir a ser o fenômeno de transporte predominante.

\subsubsection{Dispersão mecânica}

A dispersão mecânica é o processo pelo qual ocorrem misturas do contaminante devido à velocidade de percolação nos canais e nos poros individuais por eles interligados. Nestes espaços, as moléculas do contaminante se deslocam com velocidades diferentes da trajetória principal e assim afastando-se da mesma. Isto é decorrente do atrito exercido sobre o fluido, pela rugosidade e pelo tamanho dos poros presentes ao do fluxo e seguidos pelas moléculas da solução.

Estas duas características distintas que são responsáveis pela dispersão mecânica, que são: a velocidade diferencial das moléculas e a diferença nos tamanhos dos canais, causadas pelas variações no tamanho dos poros descrevem o fluxo unidimensional de massa através da equação (Shackelford, 1993):

$$
F_{m}=-D_{m} \cdot n\left(\frac{\partial C}{\partial x}\right)
$$

Sendo:

$F m=$ fluxo de massa por dispersão mecânica

$D_{m}=$ coeficiente de dispersão mecânica

Segundo Bedient (1994), a dispersão pode ocorrer de duas formas: longitudinal e transversal. A dispersão longitudinal ocorre quando o soluto é transportado na direção do fluido, e a dispersão transversal é decorrente da direção perpendicular ao fluxo. As equações 2.8 e 2.9 descrevem a dispersão para ambas as direções.

$$
\begin{aligned}
& D_{m}=\alpha_{L} v \\
& D_{m}=\alpha_{T} v
\end{aligned}
$$

Onde $\alpha_{L}$ é o coeficiente de dispersividade longitudinal e $\alpha_{T}$ é o coeficiente de dispersividade transversal. 
Em meio poroso, o fluxo não apresenta velocidade constante igual à velocidade média da advecção, fazendo com que parte do contaminante se mova mais rapidamente que outras. Essa é uma das principais causas da dispersão mecânica. Outro fator é a tortuosidade existente nos poros do solo, onde a geometria do meio influencia o afastamento das linhas de fluxo. Então o coeficiente de difusão está diretamente relacionado com a tortuosidade do meio poroso, e indiretamente dependente do teor de umidade. Portanto, à medida que o teor de umidade diminui, o caminho efetivo que o fluxo percorre, aumenta (Silva et al. 2004).

\subsubsection{Difusão molecular}

A difusão molecular é o movimento das moléculas do fluido de acordo com um dado gradiente de concentração. Leite (2001), afirma que este mecanismo é dominante quando a velocidade de percolação se aproxima de zero. Neste caso, o fluxo difusivo unidimensional de massa é regido pela $1^{\mathrm{a}}$ Lei de Fick:

$$
F_{D}=-D^{*} \cdot n \cdot \frac{\partial C}{\partial x}
$$

Sendo:

$F_{D}$ - fluxo do soluto por unidade de área e por unidade de tempo

$D^{*}$ - coeficiente de difusão molecular para uma determinada espécie do soluto, onde a concentração é $C$ e x é a direção do fluxo.

A relação $\frac{\partial C}{\partial x}$ corresponde ao gradiente de concentração (massa/volume/distância) e o sinal negativo implica que a difusão ocorre no sentido oposto ao aumento da concentração, ou seja, o transporte de massa para zonas menos concentradas.

Para um meio poroso, a $1^{\text {a }}$ Lei de Fick na equação do transporte assume fenômeno de dispersão hidrodinâmica:

$$
F_{D}=-D h \cdot\left(\frac{\partial C}{\partial x}\right)
$$

Sendo:

$F_{D}$ - fluxo do soluto por unidade de área e por unidade de tempo 
$D h$ - coeficiente de dispersão hidrodinâmica

O coeficiente de dispersão é relacionado ao coeficiente de difusão e à velocidade de fluxo média $(v)$ pela expressão:

$$
\begin{gathered}
D h=D^{*}+\alpha v \\
D^{*}=\tau . D_{0}
\end{gathered}
$$

Sendo:

$\alpha$ - é a propriedade do meio, conhecida como dispersividade.

$\tau$ - tortuosidade do meio

A tortuosidade é uma propriedade geométrica, definida como a relação entre $\frac{L}{L_{e}}$, onde L é uma linha reta entre os extremos de um caminho de fluxo tortuoso com comprimento efetivo $\mathrm{L}_{\mathrm{e}}$. Os valores de tortuosidade variam entre zero e um (Schakelford \& Daniel, 1991a).

Shackelford \& Daniel (op cit.) comentam que em solos com granulometria fina a difusão ocorre de forma mais lenta do que em solução livre. Isso se dá em função dos caminhos tortuosos de migração pela presença das partículas sólidas na área da seção transversal (Figura 2.19).

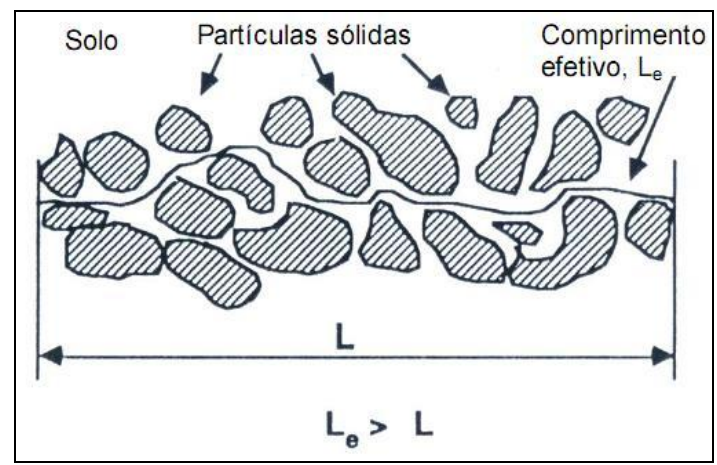

Figura 2.19 - Conceito de comprimento efetivo no transporte em solo (Schakelford \& Daniel, 1991a).

Rowe et al. (1995) lista alguns fatores que influenciam diretamente a lenta difusão no solo:

$\sqrt{ }$ Redução na seção transversal do fluxo; 
$\sqrt{ }$ Caminhos de migração mais tortuosos;

$\sqrt{ }$ Fluxo com baixo volume de fluido;

$\sqrt{ }$ Aumento na viscosidade, em especial, da água contida na dupla camada difusa;

$\sqrt{ }$ Retardamento de espécies químicas devido a troca de catiônica e aniônica;

$\sqrt{ }$ Biodegradação de solutos orgânicos;

$\sqrt{ }$ Fluxo osmótico contrário;

$\sqrt{ }$ Desequilíbrio elétrico e possível exclusão aniônica.

A velocidade do soluto quando é muito baixa no processo difusivo, contribui diretamente na dispersão. Neste caso, o coeficiente de dispersão hidrodinâmica iguala-se ao coeficiente de difusão $\left(\mathrm{D}_{\mathrm{h}}=\mathrm{D}^{*}\right)$. Quando em velocidades altas, o processo que domina a dispersão é a dispersão mecânica (Boff, 1999).

Para identificar o tipo de mecanismo de transporte predominante em um ensaio em coluna, Shackelford (1994) apresentou um parâmetro baseado no transporte advectivo e no transporte dispersivo/difusivo. Este parâmetro foi denominado pelo autor como número de Peclet $\left(P_{L}\right)$, determinado pela expressão:

$$
P_{L}=\frac{L v}{D_{h}}
$$

Sendo:

$v$ - velocidade linear média ou velocidade de infiltração.

A identificação do tipo de mecanismo dominante ocorre através dos intervalos:

- $P l \geq 50$ o transporte é dominado pela advecção;

- $P l \leq 1$ o transporte é dominado por difusão molecular.

Outros autores, como Bear (1972) e Freeze \& Cherry (1979) utilizam outra expressão que possibilitam também determinar o número de Peclet: 


$$
P_{L}=\frac{v d}{D^{*}}
$$

Sendo:

D* - é o coeficiente de difusão efetiva da espécie em meio poroso;

$d$ - diâmetro médio dos grãos para solos homogêneos;

$v$ - velocidade linear.

\subsection{Mecanismos de interação solo-contaminante}

Os processos de transporte de contaminantes geralmente podem sofrer influência das reações químicas, ocasionando alteração na concentração da solução. Essas reações podem acontecer na fase líquida, ou gerar uma transferência de soluto para a fase sólida. No caso dos solos não saturados, essas reações podem gerar transferência de massa do soluto para a fase gasosa (Freeze \& Cherry, 1979).

Leite (2001) afirma que analisar o comportamento dos materiais frente a soluções contaminantes por um longo período de exposição permite prever a retenção das espécies químicas contidas nos contaminantes. A capacidade de retenção de material é de fundamental importância para os projetos e investigações de possíveis impactos ambientais. Neste contexto, a análise dos principais processos de interação entre a fase líquida (água) e sólida do solo fornece bases para a melhor compreensão dos fenômenos envolvidos e sua quantificação.

De acordo com Yong et. al. (1992) os processos pelo qual o soluto é repartido entre a fase líquida e a fase sólida é chamado de sorção, ou processo de atenuação. Quando os processos de atenuação são de difícil distinção deve-se utilizar o termo sorção. Estes autores citam os principais mecanismos da sorção como: adsorção, complexação e precipitação.

De maneira geral, quando as moléculas presentes em fluido, líquido ou gás concentram-se espontaneamente sobre uma superfície sólida, caracteriza-se o fenômeno da adsorção. Esse fenômeno pode ocorrer como resultado de cargas elétricas desequilibradas na superfície do sólido, atraindo moléculas quando em contato com um fluido. Dessa forma, a adsorção está diretamente relacionada à tensão superficial da parte sólida. Ou seja, a influência do soluto na tensão superficial de um sólido depende da concentração desse soluto na superfície do sólido. 
De acordo com Freeze \& Cherry (1979), os processos de adsorção em meios porosos compreendem a união de íons e moléculas do fluido na superfície dos sólidos, especificamente na fração argila, em função da grande área superficial com cargas eletricamente altas. Essa união de íons e moléculas ocorre devido às forças de atração nas superfícies pelo desequilíbrio de cargas. As substituições isomórficas de íons na rede cristalina da fração argila e o rompimento de ligações nas suas estruturas moleculares geram cargas negativas. Essas cargas são equilibradas por cátions hidratados que se unem às extremidades das partículas de argilas envolvendo-as e formando a chamada dupla camada. A Figura 2.20 apresenta o esquema da dupla camada elétrica, onde as partículas de argila estão carregadas negativamente.

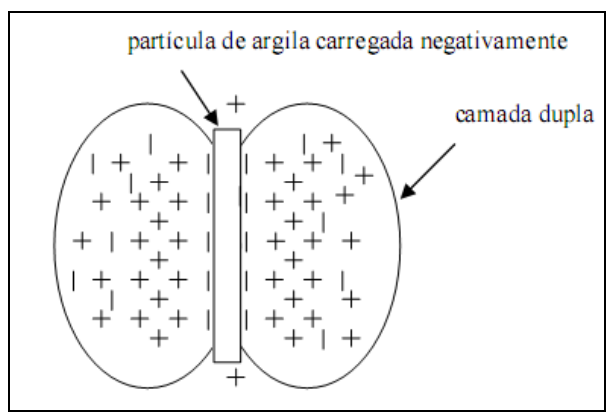

Figura 2.20 - Dupla camada elétrica e partícula de argila carregada negativamente (modificado de Oliveira, 2002).

A formação da dupla camada elétrica depende também de outros fatores, como: efeito da constante dielétrica, temperatura, tamanho do íon e do raio hidratado, $\mathrm{pH}$ do solo, adsorção aniônica, ponto de carga zero, concentração eletrolítica e valência do contra-íon (cátions, para uma superfície negativamente carregada, ânion para uma superfície positivamente carregada) (Mitchell, 1993).

Santos (1972) comenta que os argilominerais possuem íons em sua superfície que podem ser trocados através de reações químicas por outros íons, caracterizando assim a capacidade de troca.

A adsorção é analisada na forma de processo químico e físico. Basicamente, a adsorção física é um fenômeno reversível onde se observa interações intermoleculares entre o adsorbato e o adsorvente, atingindo rapidamente o equilíbrio. A adsorção química é o processo pelo qual ocorrem trocas de elétrons entre a parte sólida e a molécula adsorvida. Este fenômeno é caracterizado por formar uma única camada sobre a superfície sólida, já que na 
adsorção física ocorre a deposição de várias camadas de adsorbato sobre a superfície do adsorvente. É irreversível e libera energia em quantidades consideráveis.

Leite (1997) considera a adsorção física como o processo em que os contaminantes em solução são atraídos pelas partículas de solo, devido ao desequilíbrio de cargas. Já a adsorção química é um tipo de reação específica através da qual ocorre a ligação de elementos da fase líquida na fase sólida, por ligações covalentes.

Leite (2000) classifica a adsorção física em catiônica e aniônica. Tratando-se de cátions adsorvidos, são aqueles íons aprisionados por forças eletrostáticas ou outras forças que influenciam no potencial resultante. A capacidade de troca de catiônica (CTC) é a quantidade de cátions trocáveis retidos pelo solo (Yong et. al., 1992). Essa troca envolve a associação de cátions de soluções salinas aos pontos de cargas negativas nos sólidos do solo. Segundo Leite (2000), a CTC tem grande importância nos argilominerais de três camadas (2:1), altamente sorcivos e expansivos, do grupo da esmectita e da vermiculita. Esses argilominerais possuem elevada CTC em função da ausência de cargas e dos espaços acessíveis entre as camadas. O autor caracteriza a adsorção de ânions, como íons adsorvidos especificamente, ou seja, ânions extraídos com um ânion que o substitua e também são presos eletrostaticamente como os cátions.

Os outros processos de sorção agrupados em complexação não se fazem objeto deste trabalho, porém vale ressaltar que a complexação é o processo pelo qual um cátion metálico reage com um ânion que funciona como ligante inorgânico. $\mathrm{O}$ fenômeno da precipitação em contaminantes na fase aquosa ocorre quando há formação de novas substâncias, de maneira a ser uma nova fase insolúvel. Este fenômeno é responsável pela maioria da retenção dos metais pesados.

A quantificação da sorção é determinada experimentalmente pela medida da distribuição do contaminante em um sedimento particular, solo ou rochas através de ensaios de equilíbrio em lote. Os diversos modelos aplicados em sistemas ambientais relatam a quantidade de soluto, $\mathrm{S}$, retardada por unidade de fase sólida. Os resultados são plotados em um gráfico, originando expressões avaliadas em um sistema fixo de temperatura, conhecido como "isoterma de sorção". 
Isotermas de sorção são equações matemáticas usadas para descrever, em termos quantitativos, a sorção de solutos por sólidos, a temperaturas constantes, em função da concentração de equilíbrio do soluto.

\section{$\sqrt{ }$ Isoterma Linear}

É a situação mais simples de representação de sorção, modelado simplesmente como linear. Esta isoterma é representada por $\mathrm{S}$, que corresponde à massa de soluto adsorvida por massa de solo proporcional à concentração de equilíbrio da solução, denominada de $\mathrm{C}$. Neste caso, o ajuste de inclinação da reta corresponde ao coeficiente de distribuição $\mathrm{K}_{\mathrm{d}}$.

$$
S=K_{d} \cdot C
$$

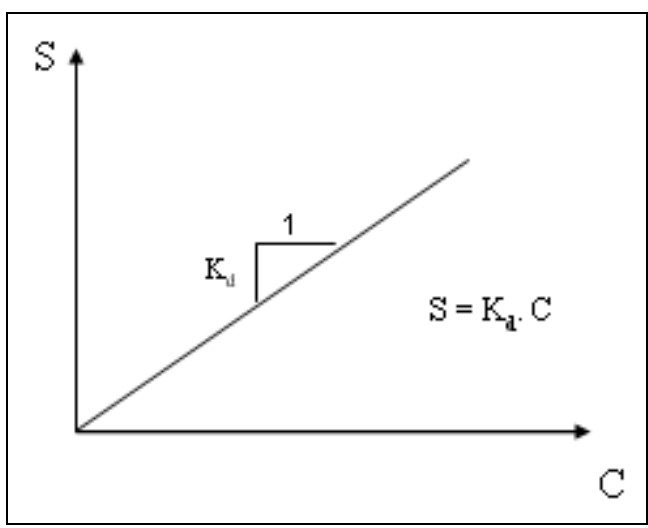

Figura 2.21 - Isoterma linear (Rowe et al, 1995).

De acordo com Rowe et. al. (1995), a relação existente entre S e C é considerada uma aproximação razoável para baixas concentrações de contaminantes.

Na prática, a isoterma de adsorção linear não representa de fato o comportamento das concentrações de soluto, pois estas são relativamente elevadas. Portanto a relação entre a variação na concentração adsorvida pela partícula sólida e a variação na concentração de equilíbrio da espécie química é representada pelo coeficiente de partição, $K_{p}$. Schakelford (1993) comenta que esse coeficiente depende da concentração de equilíbrio e o valor correspondente a tangente da isoterma para uma dada concentração de equilíbrio, C.

Para representar a sorção não-linear, as relações mais utilizadas são: 


\section{$\sqrt{ }$ Isoterma de Freundlich}

A isoterma de Freundlich é o modelo não-linear mais largamente utilizado (Weber Jr. et al., 1991), e é dado por:

$$
S=K_{d} \cdot C^{N}
$$

Sendo:

$K_{d}$ - coeficiente de distribuição

$N$ - coeficiente obtido experimentalmente

O coeficiente " $N$ ” especifica o tipo de sorção, ou seja, o tipo de isoterma. Se $N>1$ a sorção é favorável, se $N=1$, esta equação é conhecida como isoterma linear e se $N<1$ a sorção é desfavorável. A isoterma linear é apropriada para casos em que o potencial de sorção aumenta com o aumento da concentração. Segundo Weber Jr et. al. (1991), este modelo é considerado para casos em que a concentração do contaminante é baixa e quando o solo tem baixo potencial de sorção.

O gráfico resultante é então linearizado através da relação:

$$
\log S=N \cdot \log C+\log K_{f}
$$

Sendo:

$S$ - massa de soluto sorvida por umidade de massa seca de solo;

$C$ - concentração do soluto;

$K_{f}$ - coeficiente de distribuição;

$N$ - coeficiente que especifica o tipo de sorção. 


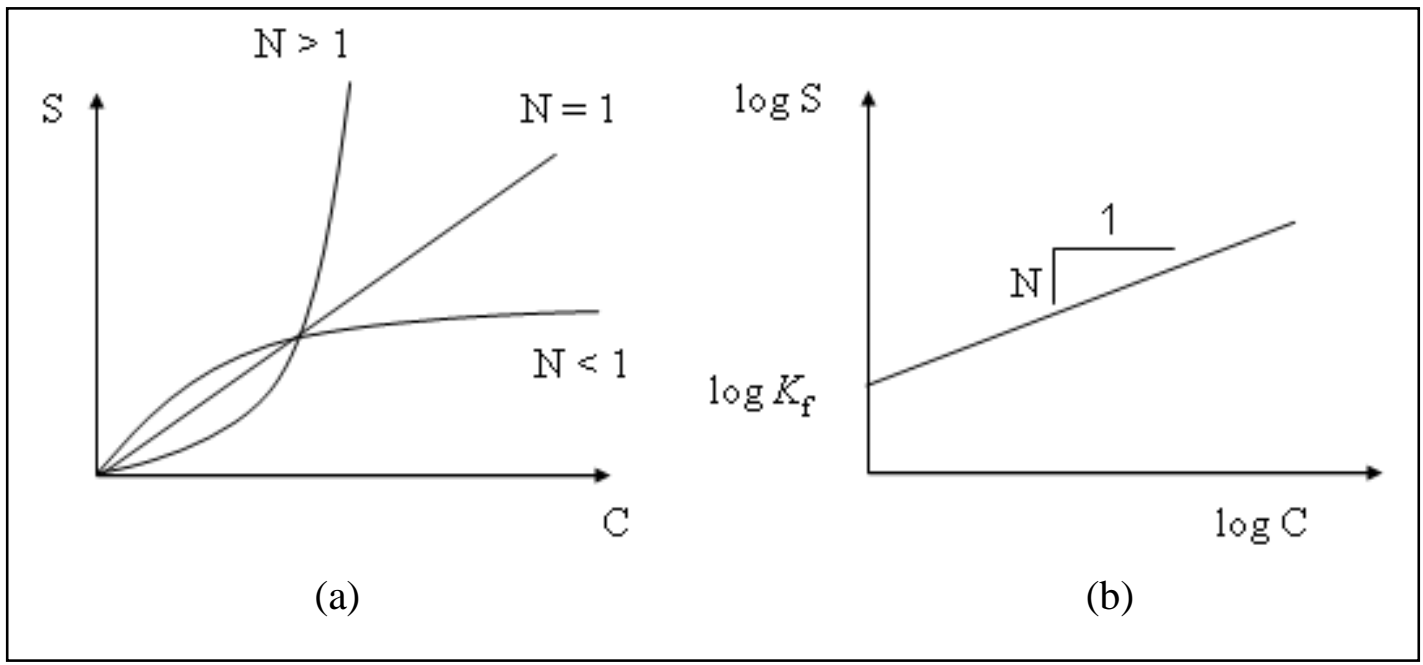

Figura 2.22 - Isoterma de Freundlich: (a) sorção como função da concentração; (b) Representação gráfica para determinação dos parâmetros (Rowe et. al., 1995).

\section{$\sqrt{ }$ Isoterma de Langmuir}

A isoterma de Langmuir é utilizada quando se quer atingir um grau maior de concentração, ou seja, quando se obtém de maiores informações das concentrações em campo. Esta isoterma pode ser expressa:

$$
S=\frac{S_{m} b C}{1+b C}
$$

Sendo:

$S_{m}$ - quantidade máxima sorvida pelo solo;

$b$ - taxa cinética constante de saída e entrada de constituintes nos sítios de adsorção;

$C$ - concentração de equilíbrio. 


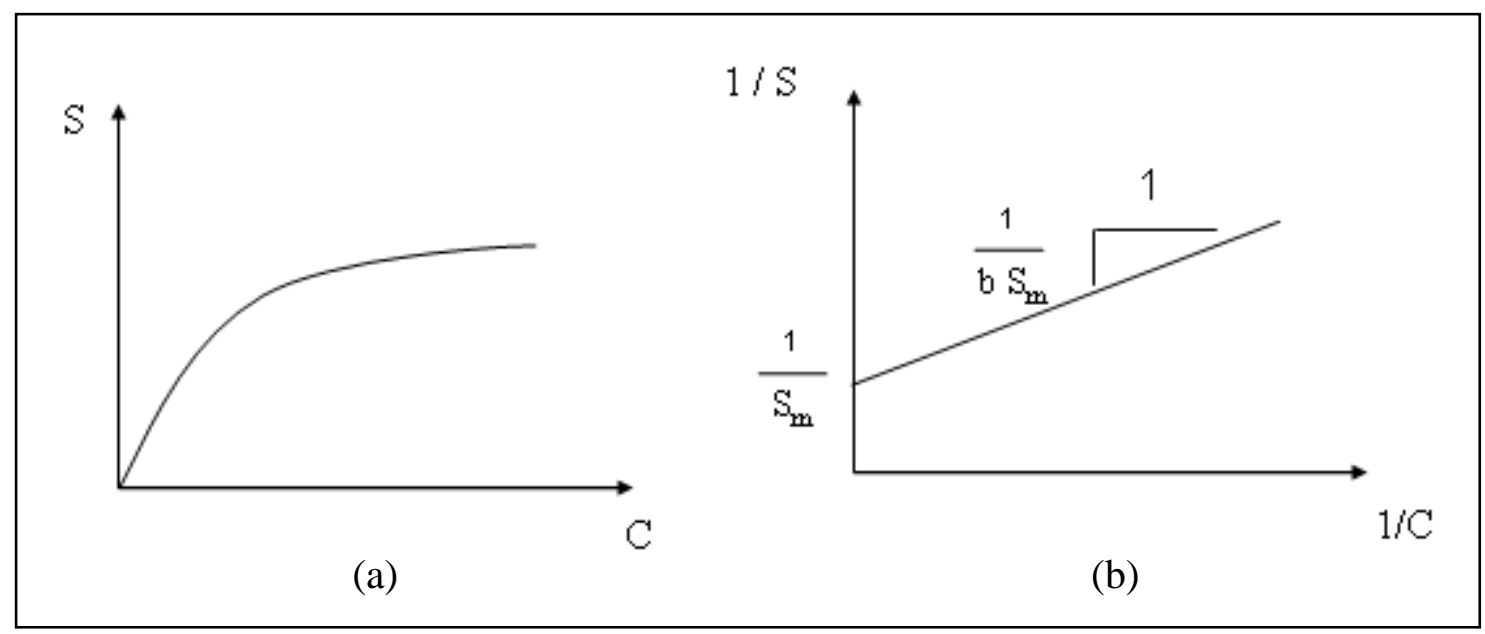

Figura 2.23 - Isoterma de Langmuir: (a) sorção em função da concentração; (b)representação gráfica para determinação dos parâmetros (Rowe et. al., 1995).

Os coeficientes $\mathrm{K}_{\mathrm{d}}$ e $\mathrm{K}_{\mathrm{f}}$ são utilizados para a determinação do fator de retardamento à partir das isotermas de Langmuir e Freundlich.

O fator de retardamento fornece informações sobre o quanto o solo retarda a chegada de uma frente de contaminação com uma determinada concentração, considerando o processo de sorção linear, reversível e um equilíbrio instantâneo. Freeze \& Cherry (1979) definem o efeito retardamento $\mathrm{R}_{\mathrm{d}}$, como a razão a velocidade média linear $\bar{v}$, e $\overline{v_{c}}$ a velocidade equivalente a $\mathrm{C} / \mathrm{C}_{0}=0,5$ :

$$
R_{d}=\frac{\bar{v}}{\overline{v_{c}}}
$$

Nos casos em que a partição do contaminante pode ser adequadamente descrita pelo coeficiente de distribuição $K_{d}$, o retardamento da frente de contaminação em relação à massa de água pode ser descrito pela relação:

$$
R_{d}=1+\frac{\rho_{d .} K_{d}}{n}
$$

Sendo:

$K_{d}$ - Coeficiente de distribuição.

$n$ - porosidade 
A capacidade de retenção do solo calculado pelo fator de retardamento, $R_{d}$, pode ser calculada também pelos critérios de Shackelford (1994). O autor propôs determinar o fator de retardamento pelo método da área acima da curva de chegada, sendo esta área equivalente ao $R_{d}$ (Figura 2.24).

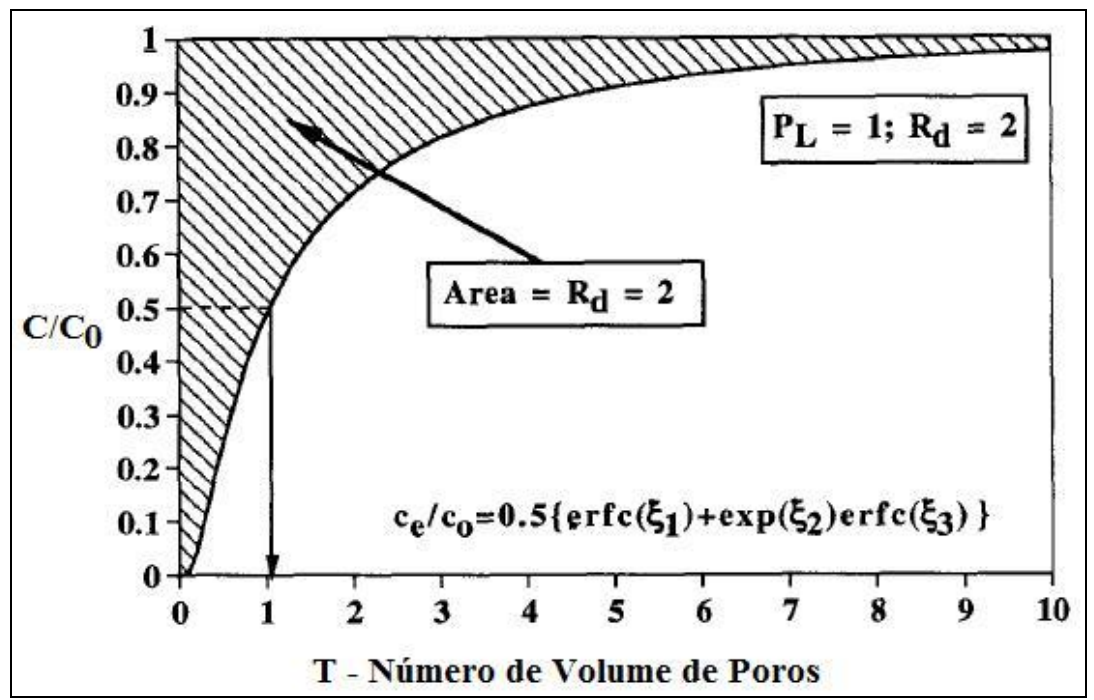

Figura 2.24 - Determinação do fator de retardamento, $R_{d}$. (Shackelford, 1994)

Este método permite calcular o fator de retardamento diretamente à partir da curva de chegada após a finalização do ensaio em coluna.

\subsection{Modelo geral para transporte de poluentes}

\subsubsection{Solutos não reativos}

O transporte de massa (soluto) em materiais porosos é descrito através de equações diferenciais baseadas no fluxo do soluto que entra e sai representado por um volume elementar do solo (Freeze \& Cherry, 1979). A equação se baseia de forma geral em:

$$
\left[\begin{array}{c}
\text { Taxa de variação } \\
\text { de massa do soluto } \\
\text { dentro do elemento }
\end{array}\right]=\left[\begin{array}{c}
\text { Fluxo do soluto } \\
\text { que sai do } \\
\text { elemento }
\end{array}\right]-\left[\begin{array}{c}
\text { Fluxo de soluto } \\
\text { que entra no } \\
\text { elemento }
\end{array}\right] \pm\left[\begin{array}{c}
\text { Perda ou ganho } \\
\text { de massa do soluto } \\
\text { devido a reações }
\end{array}\right]
$$

Para os constituintes que não sofrem atenuação no solo, ou seja, os não reativos, o transporte de soluto é descrito pelos fenômenos de advecção e dispersão hidrodinâmica através da equação (Freeze \& Cherry, 1979): 


$$
\frac{\partial C}{\partial t}=D_{h} \cdot \frac{\partial^{2} C}{\partial x^{2}}-v \frac{\partial C}{\partial x}
$$

Sendo:

$C$ - concentração do soluto

$t$ - tempo

$x$ - distância macroscópica na direção de transporte

Leite (1997) afirma que esta equação só é válida na condição de fluxo unidimensional, uniforme e estável; meio saturado, homogêneo e isotrópico e ausência de fluxo de solvente.

\subsubsection{Solutos reativos}

Alguns constituintes químicos podem sofrer reações quando em contato com o solo. Isto provoca a atração do soluto das soluções que percolam nas partículas do meio poroso. Quando este processo ocorre diz-se que o solo possui a capacidade de atenuação, por minimizar o efeito contaminante das soluções químicas.

Portanto, os solutos reativos são chamados de atenuados. Então, a equação para os solutos reativos é:

$$
R_{d} \frac{\partial C}{\partial t}=D_{h} \frac{\partial^{2} C}{\partial x^{2}}-v \frac{\partial C}{\partial x}
$$

Nesta equação leva-se em consideração o fator de retardamento, $R_{d}$. A validação de mesma segue as mesmas condições dadas à validação da equação para os solutos não reativos.

2.8 Técnicas experimentais na determinação dos parâmetros de transporte e atenuação.

São ensaios que possibilitam estimar os parâmetros necessários para avaliar o comportamento do material na implantação de liners. Estes ensaios permitem testar o comportamento do contaminante no solo, através de uma simulação muito próxima da situação real.

Os parâmetros relevantes obtidos através destes ensaios são: adsorção e atenuação dos contaminantes; volume de poros necessários para a chegada do contaminante; 
dispersão/difusão e retardamento (responsáveis pela migração). Podem ser avaliados também: a movimentação do fluido através do material estudado; o efeito das reações químicas durante o transporte e a compatibilidade do solo/contaminante.

Os equipamentos variam de acordo com a finalidade, ou seja, dependem dos parâmetros que se deseja determinar.

\subsubsection{Ensaio em coluna}

Este ensaio possibilita a percolação de soluções constituídas por substâncias químicas contidas em contaminantes através de uma coluna com amostras de solos.

Leite (2000) desenvolveu um estudo para idealizar um sistema de percolação em colunas, de baixo custo, para introduzir soluções contaminantes a pressões constantes, por tempo prolongado. Este sistema de percolação viabilizou algumas necessidades encontradas que dificultavam a eficiência operacional e a precisão das condições hidrodinâmicas e químicas. O resultado foi a construção de um equipamento passível de reutilização, cujas características relevantes são: a) a injeção contínua de soluções através de colunas de solos e; b) a redução do tempo experimental pelo processamento simultâneo de várias colunas, todas sujeitas a uma mesma pressão. A autora comenta que estes ensaios são de extrema importância e permitem a realização de várias investigações, como:

- Obtenção de parâmetros quantitativos primordiais para a simulação do movimento de contaminantes através do solo;

- Avaliar os efeitos das reações químicas e biológicas no destino dos contaminantes, durante o transporte em meio poroso;

- Obter curvas de dessorção de íons do solo através de extração química ou hidráulica;

- Testar as relações de competitividade entre diferentes íons contaminantes, quando infiltrados no mesmo corpo-de-prova;

- Testar a compatibilidade do solo/contaminante;

- Avaliar o destino e transporte de contaminantes em aqüíferos regionais. 
Segundo Basso (2003), em termos de aplicação geoambiental, o ensaio em coluna pode ser utilizado para:

a) Quantificar os parâmetros de transporte de contaminantes como: dispersão hidrodinâmica $\left(D_{h}\right)$ e fator de retardamento $\left(R_{d}\right)$;

b) Avaliar os efeitos das reações químicas e biológicas nos destinos dos contaminantes durante o transporte em meio poroso;

c) Investigar a validação e aplicabilidade das várias teorias e modelos que são utilizados para prever a migração dos contaminantes em meio poroso.

Os aparatos do ensaio, geralmente, seguem os típicos adotados em ensaios de permeabilidade. O cilindro pode ser de parede rígida ou flexível, com topo e base metálicos. Atualmente, procura-se utilizar cilindros de acrílico para melhor visualização do comportamento da amostra no ensaio. De acordo com Leite (2000), a injeção das soluções no corpo-de-prova pode ser feita por gravidade, bombeamento ou por pressão de gás ou ar comprimido.

A amostra é compactada no próprio cilindro de ensaio, e em seguida saturada com água. Inicialmente, adota-se um regime de fluxo permanente com água, até que em um tempo $\mathrm{t}=0$ introduz-se uma concentração $\mathrm{C}_{0}$ de um soluto não reativo pelo topo da coluna. $\mathrm{A}$ solução, então, ocupa o espaço que antes seria preenchido pela água. O volume de saída da concentração é medido em intervalos de tempo. As amostras são coletadas para análises químicas periódicas.

Um gráfico é plotado com a concentração de saída $C$ em função do tempo $t$, ou então, a relação $\mathrm{C} / \mathrm{C}_{0}$ em função do volume de efluente $\mathrm{V}$. A representação gráfica é chamada de curva de saturação do poluente, ou curva de chegada "breakthrough curve" (Boscov, 1997).

Além da obtenção das curvas de chegada que representam o comportamento dos íons de soluções contaminantes, Boscov (op cit.) comenta que o ensaio em coluna associado à outros ensaios permite estimar a capacidade de adsorção e o coeficiente de dispersão hidrodinâmica longitudinal. 


\subsubsection{Ensaio de equilíbrio em lote (Batch Test)}

Outro ensaio realizado para obter parâmetros é o Batch Test. O ensaio consiste na suspensão e agitação do solo seco em soluções com concentrações químicas. Nestas soluções químicas são acrescentadas concentrações variadas numa temperatura específica constante até que se estabeleça o equilíbrio físico-químico. O equilíbrio químico depende do tempo de estabilização, caracterizado pelo tempo mínimo necessário para que a mistura permaneça em contato com a solução até que ocorra a total interação entre as partes envolvidas no processo. Nas partículas que ficam em suspensão medem-se as quantidades sorvidas de solução. De acordo com Leite (2000), esta quantidade de elemento sorvida por unidade de massa de solo $(S)$ é expressa por:

$$
S=\frac{\left(c_{0}-c_{e}\right) \cdot V}{M}
$$

Sendo:

$C_{0}$ - concentração inicial

$C_{e}$ - concentração de equilíbrio

$V$ - volume de solução utilizado

$M$ - massa de solo sem umidade

O gráfico da relação entre a massa sorvida por unidade de solo seco (S) e a concentração do elemento que permanece em solução (C) são representados pela isoterma de sorção.

\subsubsection{Ensaio de difusão}

Determina a distribuição vertical da concentração através de análises químicas na amostra de solo, com velocidade de percolação igual ou próxima a zero. O ensaio consiste na aplicação da concentração de uma solução, na parte superior do corpo-de-prova, em amostras de solo (Boff, 1999). Avalia-se a movimentação das moléculas, que só cessarão quando o meio estiver em equilíbrio. Ou seja, após a dispersão espontânea da parte de maior concentração para a parte de menor concentração. 
A concentração nas amostras é monitorada por coletas em intervalos de tempo. Após o ensaio, secciona-se a amostra em discos de $1 \mathrm{~cm}$ de espessura. Para determinar o coeficiente de difusão, são plotadas curvas de concentração do fluido no reservatório de coleta em função do tempo, e concentração do fluido intersticial do solo em função da profundidade do solo (Boscov, 1997).

\subsubsection{Ensaio de compatibilidade}

São ensaios realizados antes e depois da percolação do poluente, para analisar a interação entre o solo e o contaminante. O objetivo principal destes ensaios é verificar as modificações ocorridas nas propriedades e características geotécnicas do material.

Segundo Boscov (1997), são realizados rotineiramente ensaios de granulometria, limites de Atterberg, resistência ao cisalhamento e principalmente o ensaio de permeabilidade. A condutividade hidráulica é o fator mais afetado na interação do solo/contaminante.

\subsection{Pesquisas realizadas no Departamento de Geotecnia}

Este item refere-se aos trabalhos destinados ao estudo de "Transporte e atenuação de contaminantes" produzidos no Departamento de Geotecnia da Escola de Engenharia de São Carlos (SGS - EESC).

Leite em 1997 realizou estudos de contaminação em colunas de laboratório com o objetivo de avaliar o processo de difusão molecular dos íons $\mathrm{K}^{+}$e $\mathrm{Cl}^{-}$. Foram utilizadas amostras de solo compactado e saturado das formações Botucatu e Serra Geral, ensaiados separadamente e em misturas de diferentes proporções. Os parâmetros de transporte de soluto foram obtidos através modelagem dos dados reais de contaminação, e os de retenção do $\mathrm{K}^{+}$ em ensaios Batch Test. Os resultados indicaram melhores modelamentos para o $\mathrm{K}^{+}$. O autor afirma também que a comparação simples realizada com alguns dados da literatura revela que em relação a difusão molecular para os solos estudados possuem comportamento parecido com materiais constituídos exclusivamente de argilas.

Boff (1999) realizou um estudo em misturas compactadas de materiais inconsolidados das Formações Serra Geral e Botucatu quando percoladas por soluções nas concentrações de $\mathrm{K}^{+}, \mathrm{Cl}^{-}$e $\mathrm{Cu}^{2+}$. A avaliação do potencial deste material para a aplicação em liners ocorreu foi feita por meio de ensaios em coluna. $\mathrm{O}$ autor também complementou o trabalho com um 
estudo do comportamento eletroquímico através de ensaios de titulação potenciométrica, capacidade de tamponamento, $\mathrm{pH}$ em água e $\mathrm{KCl}, \mathrm{CTC}$ e análise mineralógica por difração em raios-X e térmica diferencial. Os resultados obtidos indicaram que os materiais estudados tem qualidade para a utilização em liners, no que diz respeito à caracterização geotécnica das misturas. Quanto à retenção, o $\mathrm{Cu}^{2+}$ se mostrou satisfatório, seguido pelo $\mathrm{Cl}^{-}$e o $\mathrm{K}^{+} . \mathrm{O} \mathrm{Cl}^{-}$em solos com clima temperado possui reatividade baixa, mas em solos tropicais pode apresentar fator de retardamento $\left(R_{d}\right)$ igual ou superior ao $\mathrm{K}^{+}$. Portanto, estes materiais, quando misturados, são viáveis para o emprego em liners.

Leite (2000) desenvolveu um estudo experimental para avaliar a percolação de soluções químicas iônicas em colunas de solos compactados, visando a aplicação de materiais inconsolidados como liners. Porém, o que se tornou objetivo primordial do seu trabalho foi o desenvolvimento de um sistema de equipamentos para a realização dos ensaios. Seguindo uma ordem, foram escolhidos os materiais e as soluções químicas percoladoras. O equipamento construído basicamente é um conjunto de colunas de percolação e um distribuidor de ar, que tem como função impulsionar soluções para serem percoladas nos corpos-de-prova. O equipamento mostrou eficiência mecânica e hidráulica, assim como facilidade na sua construção e baixo custo. Os ensaios no equipamento foram realizados com misturas de solos argilosos e arenosos da Formação Botucatu e de basaltos da Formação Serra Geral. As soluções escolhidas para percolação foram de cloreto de potássio e de cobre, em três diferentes concentrações. Os resultados dos ensaios, preliminarmente, se mostraram satisfatórios para a finalidade com relação aos íons considerados. A condutividade hidráulica foi a principal diferença entre as duas misturas. A autora realizou análise físico-química em termos de $\mathrm{pH}$, Eh e condutividade elétrica. As soluções de $\mathrm{KCl}$ não provocaram alterações significativas no $\mathrm{pH}$ do efluente, já as soluções á base de $\mathrm{CuCl}_{2} \cdot 2 \mathrm{H}_{2} \mathrm{O}$ sofreram redução no $\mathrm{pH}$ do efluente intensamente.

Leite (2001) estudou a migração dos íons $\mathrm{Cd}^{2+}, \mathrm{K}^{+}, \mathrm{Cl}^{-}$e $\mathrm{F}^{-}$em latossolos residuais provenientes das Formações Botucatu e Serra Geral em três diferentes misturas destes solos, com ênfase nos processos de sorção e difusão molecular. O potencial de retenção dos íons foi avaliado através da construção de 33 isotermas de sorção obtidas por meio de ensaios de Batch Test. Os resultados de retenção apresentados pelo autor mostraram que $\mathrm{o}^{-}$ experimenta sorção sob certas condições. $\mathrm{O} \mathrm{K}^{+}$e o $\mathrm{F}^{-}$apresentaram taxas semelhantes de retenção e a sorção do $\mathrm{Cd}^{2+}$ se mostrou altamente dependente da composição da solução 
contaminante. O potencial de transporte dos íons foi avaliado através de ensaios de difusão em colunas estanques, onde os parâmetros foram obtidos através do ajuste das curvas teóricas produzidas pelo programa POLLUTE. Estes ensaios resultaram em vários valores para o coeficiente de difusão efetiva $\left(\mathrm{D}^{*}\right)$, mostrando que o fluxo difusivo dos íons diminui para os solos mais argilosos. O autor conclui que a mistura de solo Botucatu com o solo Serra Geral resulta em um aumento das taxas de sorção e diminuição do fluxo difusivo. Isso demonstra que a proposta da mistura pode ser aplicada na construção de barreiras impermeabilizantes.

Basso (2003) realizou um estudo apresentando os parâmetros de transporte e atenuação do íons $\mathrm{K}^{+}, \mathrm{Cu}^{2+}$ e $\mathrm{Cl}^{-}$obtidos em ensaios em coluna. Os solos estudados compreenderam uma mistura compactada e saturada de solos lateríticos da Formação Botucatu e Serra Geral. Foram utilizadas soluções percolantes de cloreto de potássio e de cobre em três diferentes concentrações. Os resultados deste trabalho foram apresentados na forma de curva de chegada e os parâmetros de transporte e atenuação foram estimados através do ajuste de curvas teóricas aos dados experimentais das colunas. As curvas de chegadas obtidas para as soluções de $\mathrm{KCl}$ de $\mathrm{CuCl}^{2}$ indicam que com o aumento da concentração iônica há uma diminuição da capacidade sorciva da mistura para os íons de potássio. Os resultados de $R d$ se mostraram maiores para os cátions do que para os ânions. O mecanismo de transporte predominante foi advecção/dispersão. De um modo geral, a mistura compactada mostrou-se satisfatória para o uso em liners, levando em consideração que os resultados de condutividade hidráulica e de sorção dos íons estudados são razoáveis e confirmam os obtidos por Boff (1999) e Leite (2000).

A pesquisa de Musso (2008) consistiu em analisar o comportamento de um solo argiloso proveniente da Formação Corumbataí denominado de AM-3 e de um geocomposto bentonítico (GCL) composto por bentonita sódica frente à gradientes hidráulicos e químicos. Foram realizados ensaios de advecção e difusão-membrana com solução de $\mathrm{KCl}$ e $\mathrm{CuCl}_{2} 2 \mathrm{H}_{2} \mathrm{O}$. Durante a pesquisa o autor desenvolveu um equipamento para avaliar o comportamento membrana e calcular o coeficiente de eficiência químico-osmótico através dos ensaios de difusão-membrana. $\mathrm{O}$ autor relata que comportamento hidráulico dos materiais quando percolados com soluções de $\mathrm{KCl}$ não apresentaram mudança em seu desempenho. Porém, o GCL quando percolado $\mathrm{CuCl}_{2} 2 \mathrm{H}_{2} \mathrm{O}$ apresentou um aumento de 200 vezes após alguns dias de ensaio na condutividade hidráulica. Este aumento deve-se ao fato da destruição da estrutura da dupla camada elétrica pelo cátion divalente $\left(\mathrm{Cu}^{2+}\right)$. Os ensaios de advecção e 
difusão-membrana realizados na AM-3 mostraram através do balanço de massa que foi utilizado entre 30 a $60 \%$ da CTC do material, enquanto que para o GCL estes ensaios pelos íons $\mathrm{K}^{+}$e $\mathrm{Cu}^{2+}$ a CTC foi usada totalmente. É provável que este comportamento esteja relacionado com a porosidade do GCL, que facilita a adsorção e as trocas iônicas. O fator de retardamento $\mathrm{R}_{\mathrm{d}}$ apresentou valores semelhantes tanto para $\mathrm{K}^{+}$como para $\mathrm{Cu}^{2+}$ quando ensaiados por advecção na AM-3. Quando determinados através de parâmetros do ensaio de equilíbrio em lote são sempre maiores, mas são considerados valores de referência para avaliar o andamento dos ensaios de advecção e difusão-membrana.O autor concluiu também que a AM-3 apresenta condutividade hidráulica maior em relação ao GCL, porém esta desvantagem é compensada quando se aumenta a espessura da camada de solo, gerando um aumento na capacidade de adsorção em relação ao GCL. Quanto ao efeito da pressão osmótica, quando aumentada, influencia diretamente na diminuição da taxa de chegada do soluto. O processo de difusão efetiva dos íons $\mathrm{K}^{+}$e $\mathrm{Cl}^{-}$na $\mathrm{AM}-3$ dependeram da concentração. Para as condições e soluções na pesquisa de Musso (2008), para efeito de comparação do desempenho entre o solo da AM-3 e o GCL, foi observado que a combinação da espessura, porosidade do corpo-de-prova e a CTC da amostra apresentou um desempenho melhor da AM-3 em relação ao GCL. 



\section{MATERIAIS E MÉTODOS}

\subsection{Materiais estudados}

Os materiais utilizados nesta pesquisa foram objeto de recentes estudos (Musso, 2008). O presente trabalho é um estudo complementar sobre a utilização desses materiais como liner, que consistem de amostras de solo provenientes da Formação Corumbataí e um geocomposto bentonítico (GCL) fabricado no Brasil pela OBER.

A Formação Corumbataí foi escolhida por aflorar em regiões próximas às zonas de recarga do aqüífero Guarani no interior do estado de São Paulo e nas regiões de Rio Claro, Piracicaba, Limeira e Pirassununga. O geocomposto bentonítico (GCL) da OBER foi selecionado por ser o único GCL fabricado nacionalmente e ser ainda, relativamente, pouco estudado.

De acordo com Landim (1967), a Formação Corumbataí é formada por sedimentos essencialmente argilosos, de coloração arroxeada ou avermelhada com intercalações de lentes de arenito muito fino, aflorantes no vale do rio Corumbataí. Essa unidade sedimentar e as Formações Iratí e Serra Alta compõem o Grupo Passa Dois.

Na Figura 3.1 encontram-se os pontos onde foram coletadas as amostras de solo da Formação Corumbataí, sendo o ponto 1 o local de extração das amostras de solo utilizadas nesta pesquisa. E os outros pontos são os locais onde foram coletadas as demais amostras estudadas por Musso (2008). 


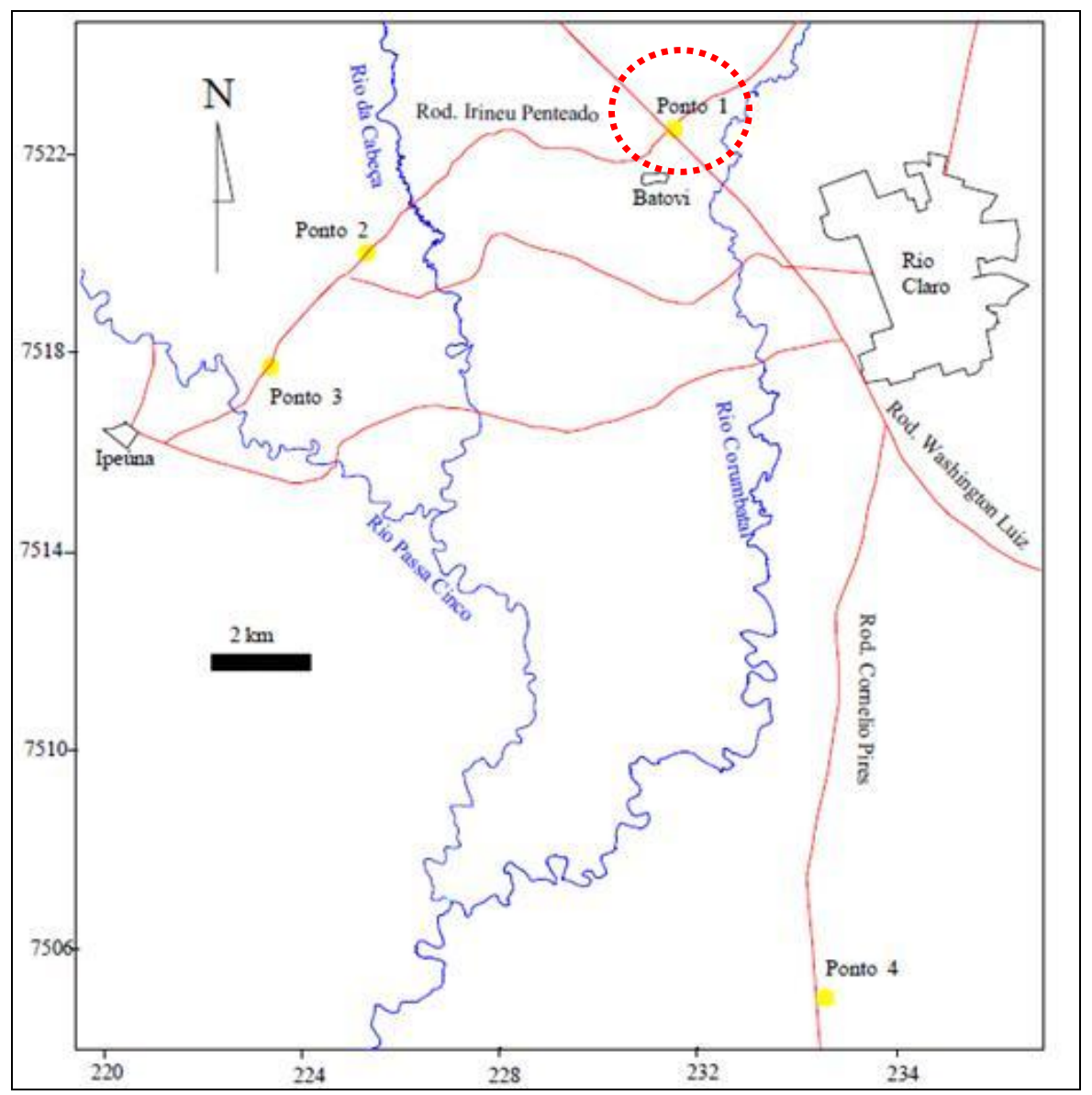

Figura 3.1 - Mapa de localização das coletas de amostras de solo da Formação Corumbataí (Musso, 2008).

\subsection{Caracterização do material e ensaio em coluna}

O material foi caracterizado por Musso (2008) de acordo com as regulamentações da ABNT para determinar: a massa específica (NBR 6508), os limites de Atterberg (NBR 6459 e 7180) e os parâmetros de compactação através de ensaios Proctor Normal (NBR 7182). A mineralogia da fração argila foi realizada por difração de raios-X, e a Análise Térmica Diferencial, segundo os critérios de Grim (1953) e Mackenzie (1957). A CTC foi determinada de acordo com o método descrito por Pejon (1992). A caracterização da bentonita e das propriedades hidráulicas do GCL foram realizadas por Bueno et. al. (2002) e Dourado (2003).

\subsubsection{Equipamento para ensaio em coluna}

O sistema de percolação em colunas utilizado neste trabalho foi baseado no equipamento construído por Leite et al. (1998) e Boff (1999), modificado por Basso (2003). O equipamento consiste de uma fonte de distribuição de pressão através de ar comprimido, 
com painel e dispositivos de controle (Figura 3.2a), assim como reservatórios de solução (Figura 3.2b) e colunas de percolação com reservatório coletor (Figura 3.2c).

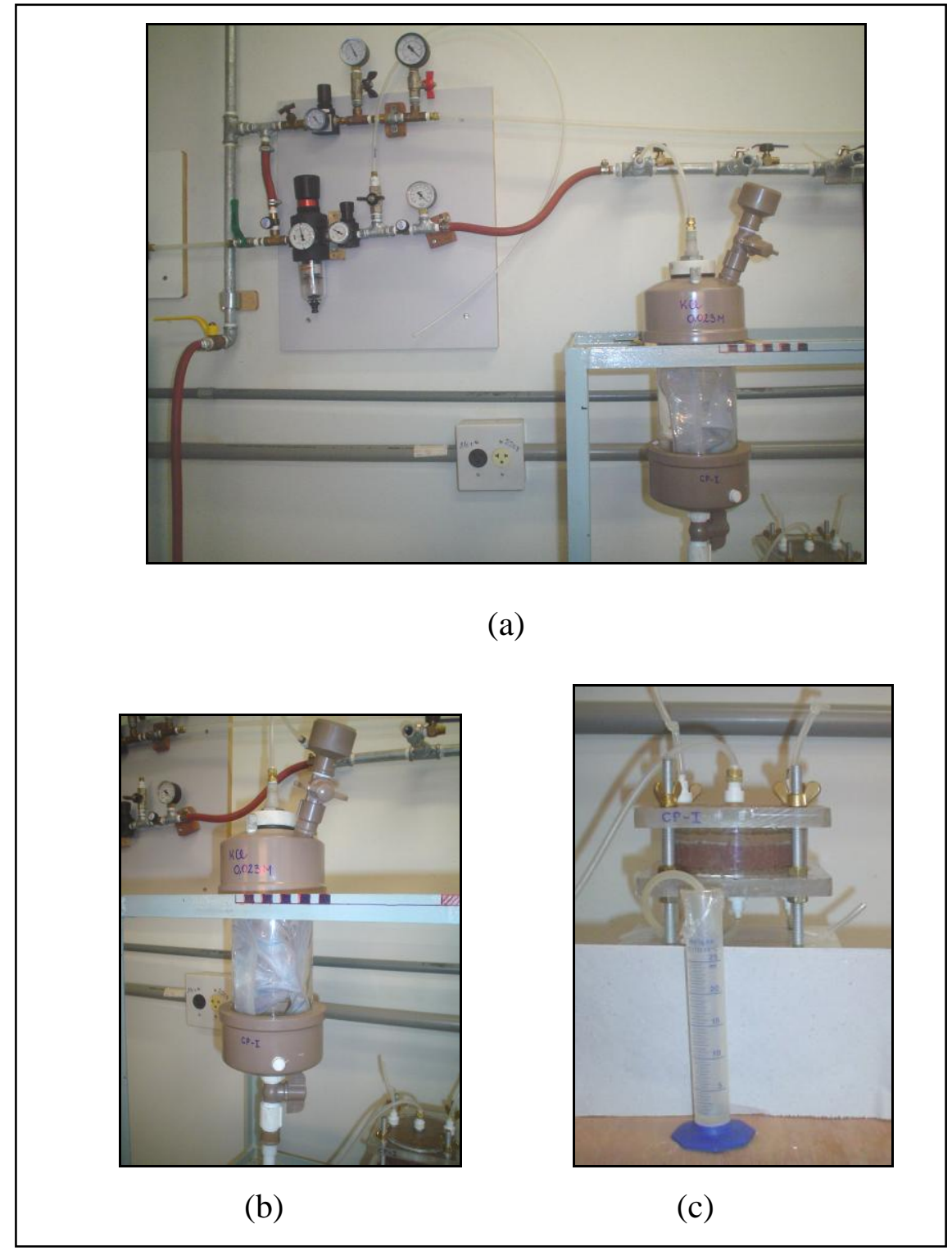

Figura 3.2 - Equipamento para ensaio em coluna: (a) painel com dispositivos para o controle da pressão; (b) reservatório para recarga de solução contaminante; (c) coluna de percolação e coletor de efluentes.

A Figura 3.2 apresenta o esquema de funcionamento do sistema de distribuição de pressão. Os reservatórios são constituídos de tubos transparentes de acrílico (plexiglass), permitindo a visualização de possíveis vazamentos, assim como das câmaras infláveis em seu interior. Esses reservatórios têm a capacidade de $1600 \mathrm{~mL}$ e são constituídos de tubos de 250 mm de comprimento por $92,8 \mathrm{~mm}$ de diâmetro e com parede de espessura de $0,35 \mathrm{~mm}$. As câmaras infláveis foram confeccionadas no departamento de Geotecnia da Escola de 
Engenharia de São Carlos (EESC), com PVC transparente nas dimensões de $320 \mathrm{~mm}$ e 190 mm.

A coleta de efluentes foi feita com provetas graduadas de $25 \mathrm{~mL}$, e para evitar o contato direto do líquido a ser recolhido com as partículas presentes no ar, vedaram-se as provetas com plástico filme e as mangueiras foram inseridas através de um orifício no próprio plástico filme (Figura 3.2c).

\subsubsection{Construção das células de percolação}

As colunas de percolação desenvolvidas especialmente para este trabalho, são constituídas basicamente de um cilindro de acrílico, com altura de 3,4 $\mathrm{cm}$ e diâmetro de 9,4cm, com duas tampas móveis que compõem o topo e a base. Em cada uma das tampas foi moldado, com auxílio do torno mecânico, um sulco concêntrico homogeneamente distribuído na mesma direção do diâmetro do cilindro (Figura 3.3a). Estes sulcos proporcionam maior fixação das tampas ao cilindro quando comprimidas através de 4 hastes (tirantes) com rosca e porca.

Foram moldadas também concavidades em ambas as tampas, homogeneamente na área da seção transversal do cilindro para servir como reservatório de distribuição uniforme de solução contaminante em toda área da seção do corpo-de-prova (Figura 3.3c). Esta concavidade que simula um reservatório dentro do cilindro evita a possibilidade da ocorrência de fluxos preferenciais. 


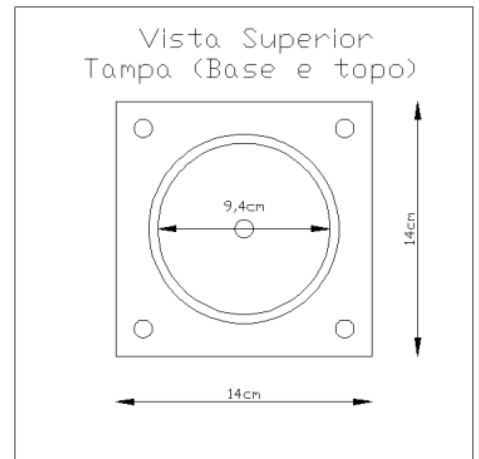

(a)

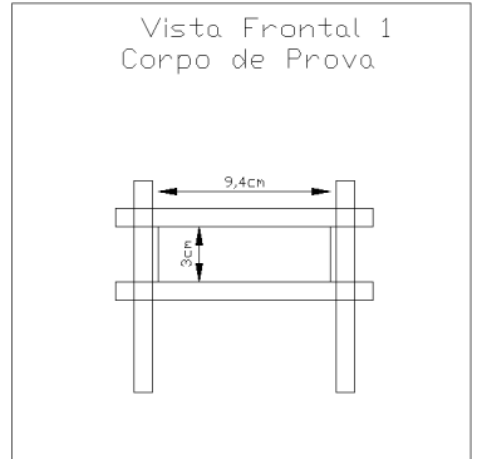

(b)

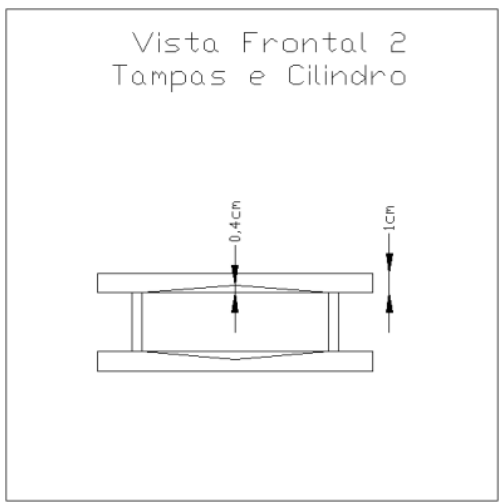

(c)

Figura 3.3 - Projeto de construção do corpo-de-prova: (a) Detalhes da tampa a ser fixada na base e topo do cilindro; (b) Dimensões do corpo-de-prova; (c) Detalhe da concavidade moldada nas tampas para servir de reservatório.

\subsubsection{Etapas do ensaio}

Foram realizados simultaneamente dois ensaios em colunas de solo com carga hidráulica aplicada de $100 \mathrm{kPa}$. Esta pressão é o valor máximo utilizado para ensaios em materiais aplicados às barreiras impermeabilizantes (Leite, 2000). As etapas do ensaio consistiram em:

(a) Compactação das colunas com as amostras de solo da Formação Corumbataí e inserção do GCL nas colunas. Os corpos-de-prova (CP) receberam a seguinte denominação:

- CP-1 para a coluna composta com GCL acima da camada de solo compactada;

- CP-2 para a coluna composta com GCL abaixo da camada de solo compactada.

(b) Saturação dos corpos-de-prova com água destilada/deionizada;

(c) Percolação com solução contaminante de cloreto de potássio $(\mathrm{KCl})$. 
(d) Coleta de solução dos CPs em frascos de polipropileno para caracterização físicoquímica ( $\mathrm{pH}$, condutividade elétrica - $\mathrm{CE}$ e o potencial redox - Eh) e análises quantitativa dos íons $\mathrm{K}^{+}, \mathrm{Cl}^{-}$e Na${ }^{+}$(Figura 3.2c).

A finalização do ensaio se dá quando a concentração efluente atinge a concentração inicial, ou seja, quando a concentração relativa $\left(\mathrm{C} / \mathrm{C}_{0}\right)$ é igual a 1 . Após obtenção dos valores de concentração coletados e o volume de vazios percolados constrói-se a curva de chegada (breakthrough curve) para determinar o fator de retardamento e o coeficiente de dispersão hidrodinâmica.

$\sqrt{ }$ Compactação das colunas

A compactação das colunas de solo da Formação Corumbataí foi realizada de forma estática diretamente nos cilindros de acrílico em duas camadas através do compactador de amostras reduzidas, com energia Proctor Normal (Figura 3.4). As amostras foram compactadas com valores de umidade ótima e massa específica seca máxima semelhante aos valores obtidos nos ensaios de compactação obtidos por Musso (2008).

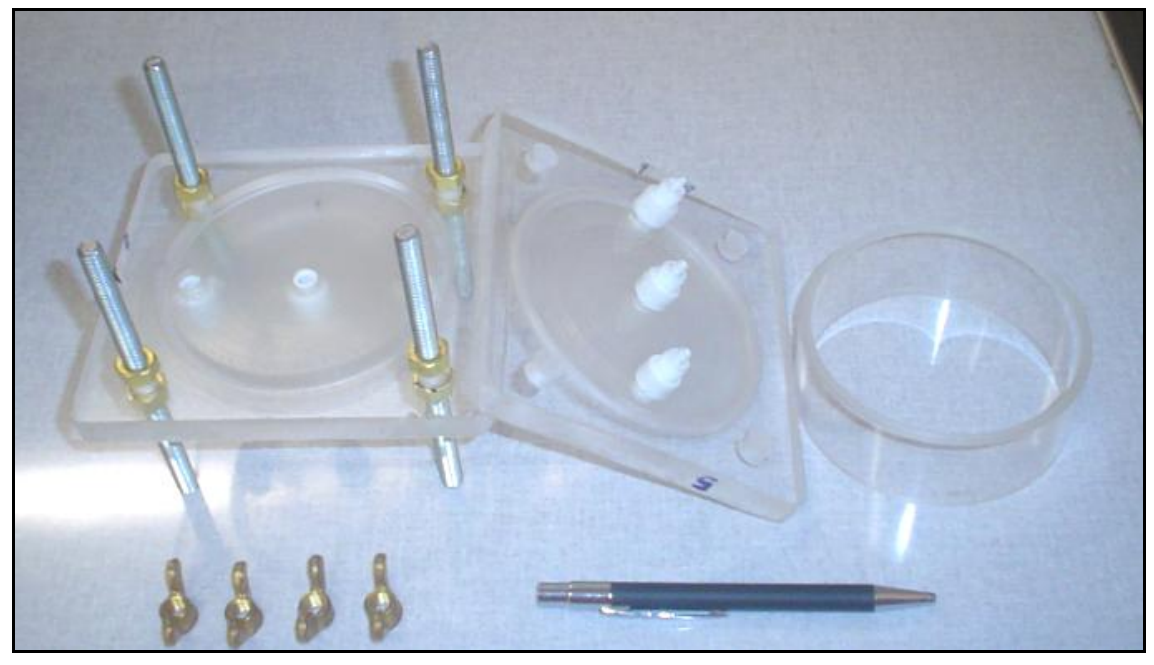

(a) 


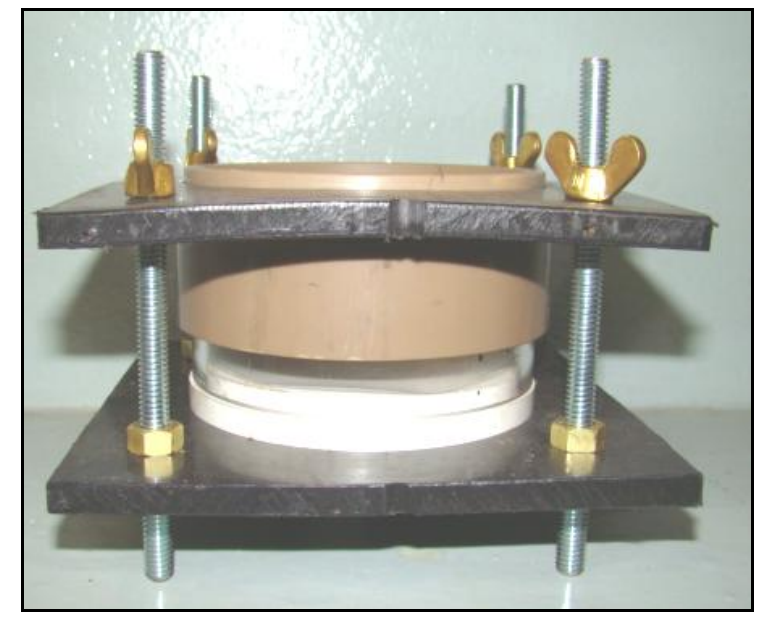

(b)

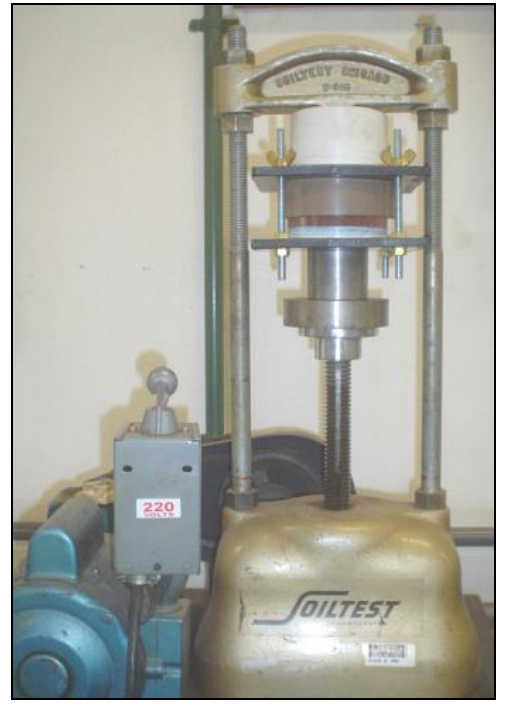

(c)

Figura 3.4 - Equipamento para compactação do corpo-de-prova na célula de percolação: (a) peças componentes da célula de percolação; (b) peças componentes para a compactação do solo no cilindro de acrílico; (c) compactador de amostras.

Para a obtenção da umidade ótima das amostras de solo, tirou-se a média de três determinações em laboratório. Essas determinações consistiram em pesar cápsulas com uma quantidade do material já umedecido e com volume de água necessário para atingir a umidade ótima do Proctor Normal. Em seguida, foram calculadas as massas de solos necessárias para a compactação das camadas através do volume do corpo-de-prova na altura de 1,35 cm e da massa do solo seco.

Após a compactação da amostra de solo no cilindro de acrílico, inseriu-se o GCL nos dois corpos-de-prova de acordo com as disposições especificadas no item de "etapas do ensaio". Foram colocadas pedras porosas no topo e na base dos corpos-de-prova e para evitar o contato entre o material e as pedras, colocaram-se também malhas de nylon permeável. A base e o topo de cada célula foram confeccionados com o mesmo material do cilindro, ou seja, de acrílico. As pedras porosas de areia foram confeccionadas de acordo com o método desenvolvido por Stancatti (1991). As conexões em PVC e nylon foram desenvolvidas pela oficina mecânica do departamento de Geotecnia EESC/USP. A Figura 3.5 apresenta as peças componentes para a montagem das células. 


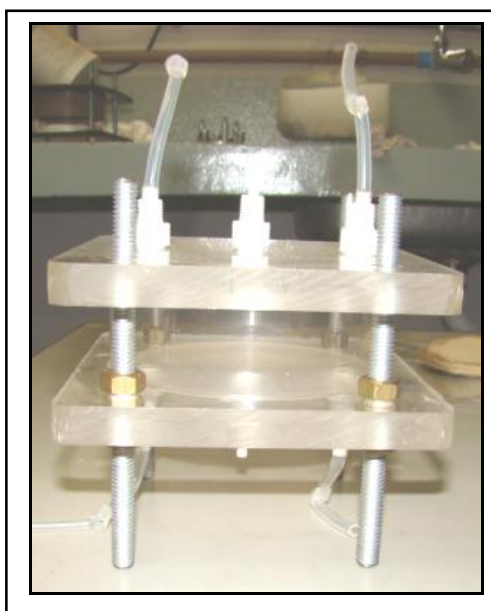

(a)

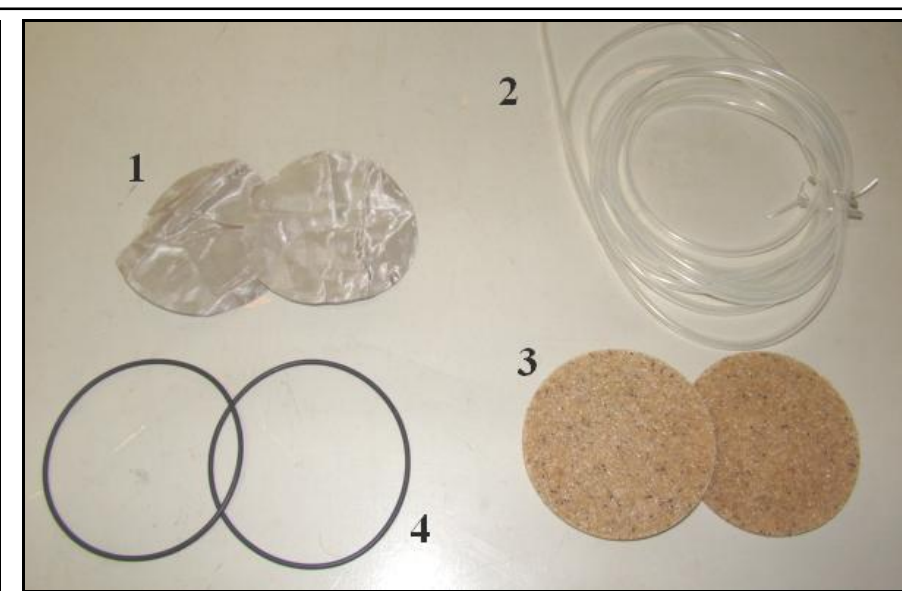

(b)

Figura 3.5 - (a) cilindro com base e tampa de acrílico para compactar o solo; (b) peças componentes da célula: malha \# 400 mesh (1), mangueira (2), pedras porosa (3) e o-rings (4).

O molde do GCL foi marcado através do diâmetro interno do cilindro. O corte foi realizado com auxílio de uma tesoura. No entanto, o corte apresentou dificuldade devido a espessura do GCL. Assim, as bordas foram levemente umedecidas com água destilada/deionizada através de uma seringa plástica. A Figura 3.6 apresenta o material utilizado para o corte e o GCL cortado na dimensão do corpo-de-prova $(9,4 \mathrm{~cm})$.

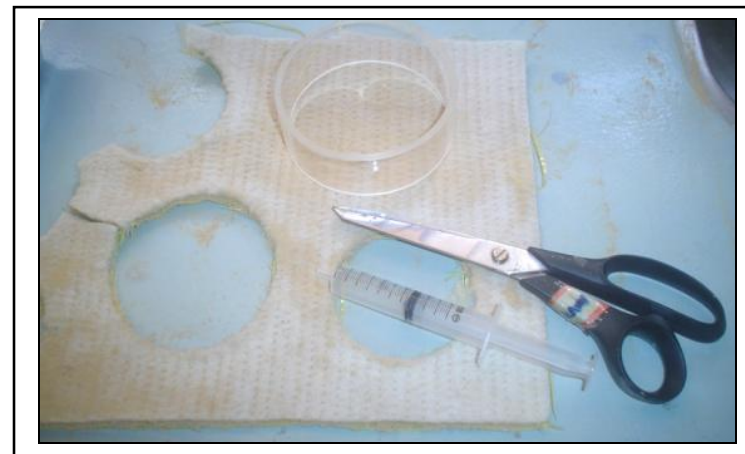

(a)

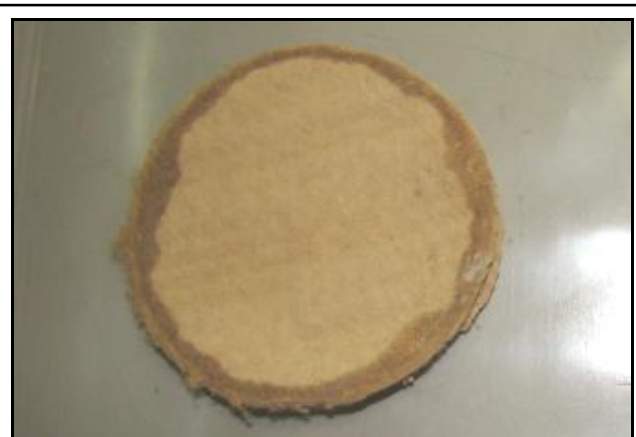

(b)

Figura 3.6 - (a) Corte do GCL fabricado pela empresa OBER; (b) GCL cortado na dimensão da célula de percolação.

\section{$\sqrt{ }$ Saturação}

Os reservatórios foram limpos e devidamente testados para verificação de possíveis vazamentos. Após a montagem das células de percolação e das colunas realizou-se a saturação na direção base/topo. As colunas foram saturadas com água destilada/deionizada. Nesta etapa determinou-se a vazão efluente assim como a condutividade hidráulica. 
Inicialmente, na montagem do CP-1, a saturação foi realizada com incrementos de pressão em intervalos de $20 \mathrm{kPa}$ para verificar a perfeita funcionalidade do sistema e ocorrência de possíveis vazamentos. Ao atingir a pressão de $100 \mathrm{kPa}$ observou-se a estabilização da vazão para dar início ao processo de percolação com solução contaminante. No caso do CP-2, a etapa de incrementos de pressão foi descartada, pois já tinha sido possível perceber a sensibilidade do ensaio. Dessa forma, a pressão aplicada desde o inicio do ensaio foi de $100 \mathrm{kPa}$.

Segundo Basso (2003) esta etapa tem como finalidade três requisitos básicos: (a) reduzir a concentração iônica do líquido nos poros, (b) obter a saturação do corpo-de-prova próximo a $100 \%$ e (c) atingir a condições de fluxo estacionário, onde a condutividade hidráulica se mantém constante.

Iniciada a etapa de saturação, anotou-se em uma planilha de monitoramento diário os seguintes dados: data, hora e volume percolado. A temperatura ambiente é outro parâmetro a ser monitorado, pois influencia significativamente os resultados. Portanto os ensaios foram realizados em temperatura de $23^{\circ} \mathrm{C} \pm 1$. A coleta de efluentes na etapa de saturação foi diária, com volume coletado em cerca de $10 \mathrm{~mL}$ (Figura 3.7). Foram realizadas análises quantitativas com o volume coletado de efluentes para verificar a quantidade de íon $\mathrm{K}^{+}$e $\mathrm{Na}^{+}$que estavam sendo lixiviados.

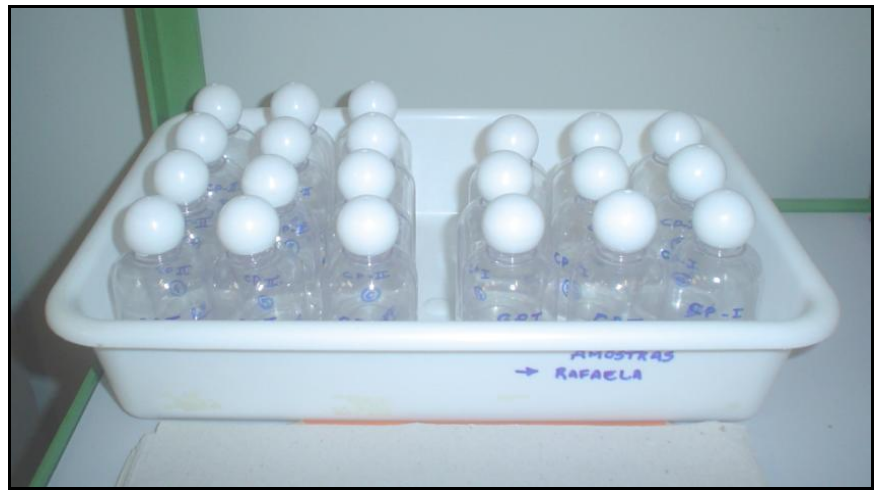

Figura 3.7 - Frascos de armazenamento das soluções coletadas para análise físicoquímica.

$\sqrt{ }$ Percolação com solução contaminante

A percolação nas colunas foi realizada através de soluções aquosas de cloreto de potássio. Durante esta etapa adotaram-se as mesmas condições de monitoramento, como condutividade hidráulica e análise quantitativa dos íons $\mathrm{K}^{+}, \mathrm{Na}^{+}$e $\mathrm{Cl}^{-}$, e também 
caracterização físico-química dos efluentes. A frequência dos intervalos de leitura foi diária, porém a coleta de efluentes foi realizada em intervalos de 3 a 4 dias para o CP-1 e de 2 dias para o CP-2.

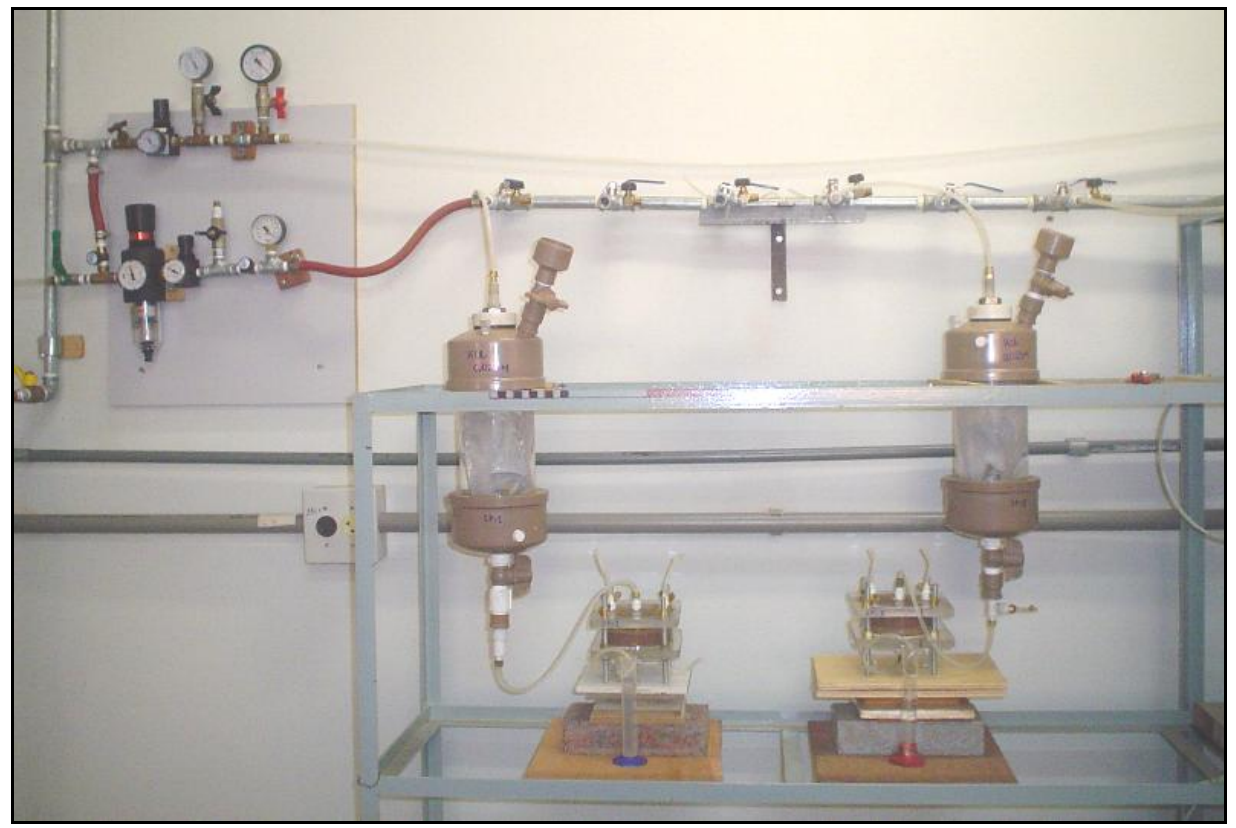

Figura 3.8 - Esquema geral do equipamento para ensaio em coluna.

- Preparação da solução contaminante

A solução contaminante de $\mathrm{KCl}$ foi preparada em somente uma concentração para ambos os corpos-de-prova ensaiados.

A concentração de solução de $\mathrm{KCl}$ utilizada foi de $0,023 \mathrm{M}$, correspondente a 1713,5 $\mathrm{mg} / \mathrm{L}$ de solução. O cálculo da concentração foi efetuado através da química estequiométrica dos compostos, baseado na massa atômica de cada íon. A Tabela 3.1 apresenta a concentração da solução detalhada para cada íon.

Tabela 3.1 - Concentração em mg/L dos íons utilizados na solução.

\begin{tabular}{lcc}
\hline \multicolumn{3}{c}{ Concentração Iônica } \\
\hline $\mathrm{KCl}$ & $\mathrm{K}^{+}$ & $\mathrm{Cl}^{-}$ \\
1713,5 & 897,0 & 816,5 \\
\hline
\end{tabular}


- Processo de recarga da solução contaminante no sistema

De acordo com a Figura 3.9, para recarregar a célula com solução contaminante, inicialmente, fecha-se a válvula na saída da célula (1). Em seguida, fecha-se a válvula de entrada de ar na bexiga onde a pressão é aplicada (2), e a válvula que alivia a pressão do sistema de distribuição de ar é aberta para que o ar presente na bexiga seja liberado. A torneira de PVC (3), localizada no topo da célula, é aberta, para que o reservatório seja recarregado com solução através do funil (4) até completar o volume da mesma. Após a recarga, a válvula é aberta novamente, e a pressão de ar no manômetro é estabilizada rapidamente.

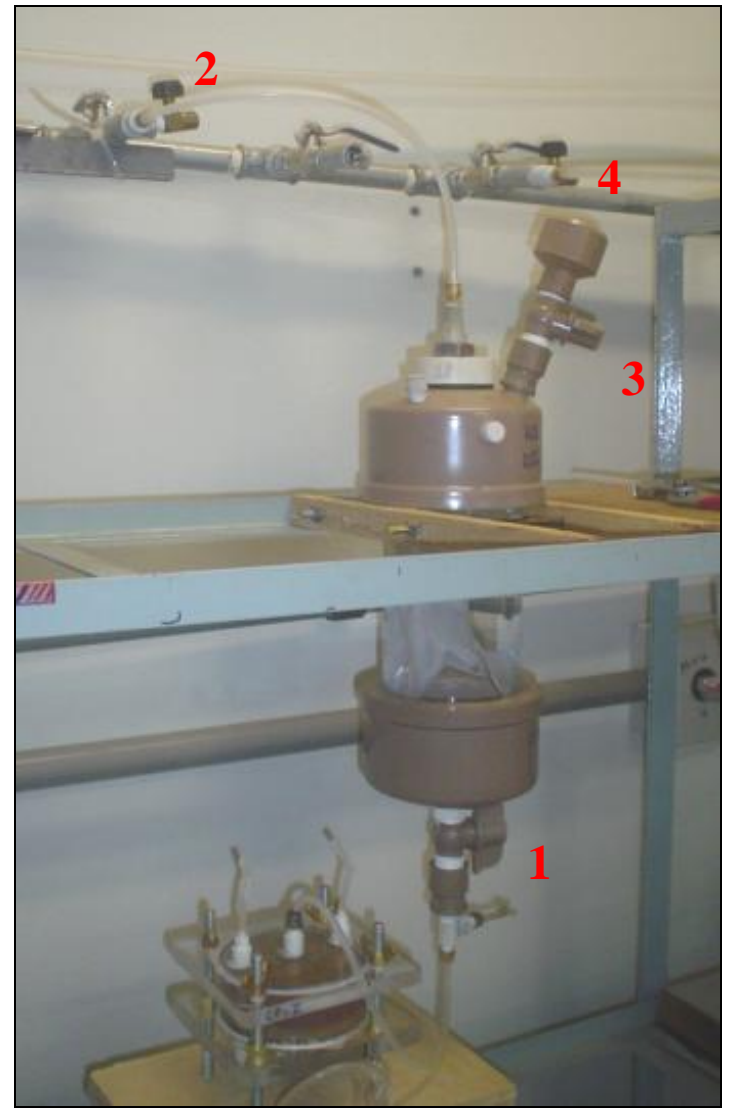

Figura 3.9 - Partes do equipamento componentes do processo de recarga de solução contaminante.

Este procedimento é realizado para cada um dos corpos-de-prova, visto que, cada coluna possui um reservatório. Para cada reservatório utilizou-se cerca de 1,5 litro de solução contaminante á cada recarga. A recarga foi realizada somente quando os reservatórios apresentavam pequeno volume. 
$\sqrt{ }$ Análise química quantitativa

As análises químicas foram realizadas no laboratório de Geoquímica do Departamento de Geotecnia da EESC. As substâncias químicas presentes na solução contaminante utilizada nesta pesquisa constituem características individuais, porém quando combinadas na forma de composto e entram em contato com o solo podem ocasionar efeitos que alteram as propriedades hidráulicas do mesmo.

\section{Sódio $\left(\mathrm{Na}^{+}\right)$}

Foram realizadas análises químicas para verificar a lixiviação de sódio do interior do corpo-de-prova tanto na fase de saturação com água destilada/deionizada como na fase de percolação com solução contaminante. Para a determinação deste cátion utilizou-se a mesma técnica para a determinação do potássio, cujo equipamento está ilustrado da Figura 3.10.

\section{Potássio $(\mathrm{K})$}

É um elemento químico que se encontra no solo na forma iônica, $\mathrm{K}^{+}$, em solução ou como cátion trocável, pode ser chamado de potássio trocável quando encontrado adsorvido nas colóides do solo. Pode ser removido por soluções de sais neutros em um curto espaço de tempo.

$\mathrm{Na}$ Tabela periódica é um elemento pertencente ao grupo 1A, correspondente ao grupo dos metais alcalinos. Apresenta massa atômica de 39,102 e raio atômico de 2,27\% A. Na forma de composto apresenta alta solubilidade em água.

De acordo com Tchobanoglous et. al. (1993 apud Basso, 2003), a concentração de potássio típica em líquidos percolado de aterros sanitários ocorre na faixa de referência de 200 a $1000 \mathrm{mg} / \mathrm{L}$ e em aterros antigos de 50 - $400 \mathrm{mg} / \mathrm{L}$.

Para a determinação deste cátion foi utilizada a técnica da fotometria em chama em um fotômetro da marca MICRONAL modelo B262. Este equipamento apresenta faixa de leitura para concentração entre 1 - $12 \mathrm{mg} / \mathrm{L}$, sendo necessário diluir as amostras coletadas em água destilada deionizada na razão 1:50 (1ml de amostra coletada para em $50 \mathrm{ml}$ de água destilada/deionizada). Realizaram-se também calibrações no equipamento com soluções padrões nas concentrações 2,5 e 5,0 mg/L. A Figura 3.10 apresenta o equipamento utilizado neste ensaio. 


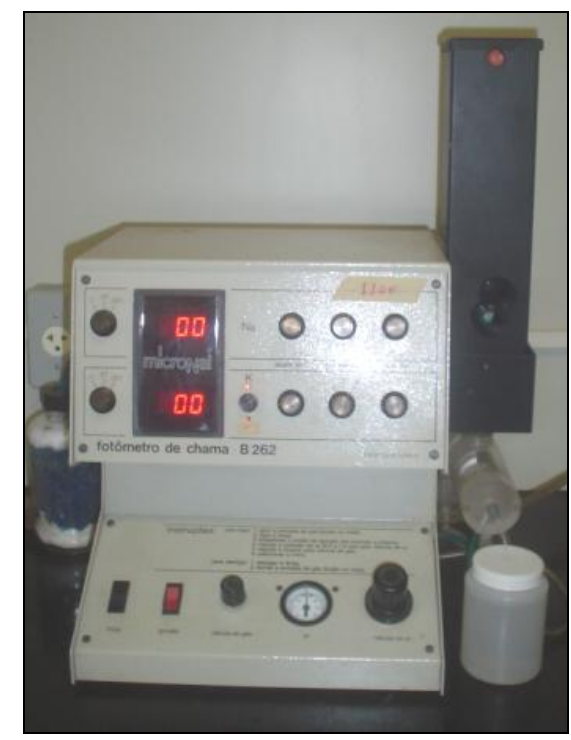

Figura 3.10 - Fotômetro de chama da marca MICRONAL, modelo B262.

Neste equipamento também foram determinadas as concentrações de sódio $\left(\mathrm{Na}^{+}\right)$ presentes em cada uma das amostras coletadas.

\section{Cloro $(\mathrm{Cl})$}

Não é encontrado na natureza em estado puro, mas sim combinado a outros elementos e compostos químicos, por reagir com rapidez. Na Tabela periódica é um elemento ametal, com símbolo $\mathrm{Cl}$, pertencente ao grupo 17 ou $7^{\mathrm{a}}$, correspondente aos halogênios. Tem número atômico 17 com massa atômica 35,5.

Em sua forma iônica negativa, o íon cloreto $\left(\mathrm{Cl}^{-}\right)$apresenta-se combinado à outros elementos. É o halogênio mais abundante na água do mar, na forma de cloreto de sódio com concentração de $1800 \mathrm{mg} / \mathrm{L}$. Forma numerosos sais, obtidos á partir dos cloretos por processos de oxidação, geralmente, mediante á eletrólise. Combina-se facilmente com a maior parte dos elementos.

Este ânion foi determinado no espectrofotômetro da marca HACH 2010. As amostras foram diluídas em razões de acordo com o aumento da passagem de concentração de cloro pelo corpo-de-prova, nas razões 10:50, 1:50, 0,5:25. A Figura 3.11 apresenta o equipamento utilizado na determinação do cloro. 


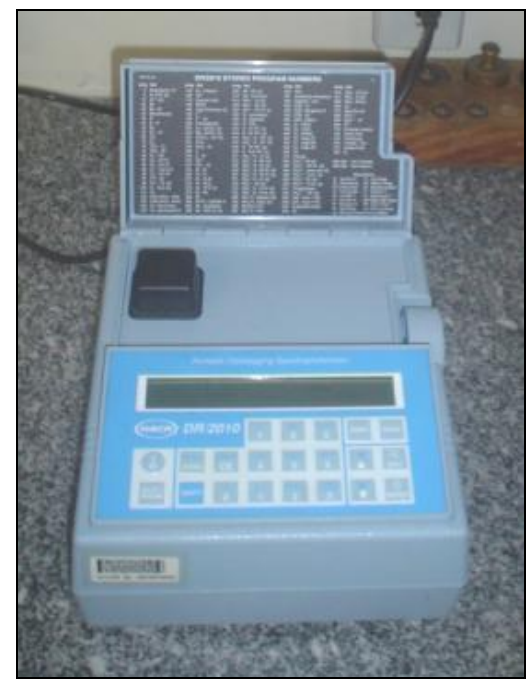

Figura 3.11 - Espectrofotômetro da marca HACH modelo 2010.

$\mathrm{O}$ pH da solução foi determinado em um pH-metro da marca Digimed modelo DM21, e o Eh em pH-metro da marca MICRONAL modelo B374. Para a determinação da condutividade elétrica utilizou-se o condutivímetro da marca ANALYSER modelo 650. A Figura 3.12 apresenta os respectivos equipamentos.

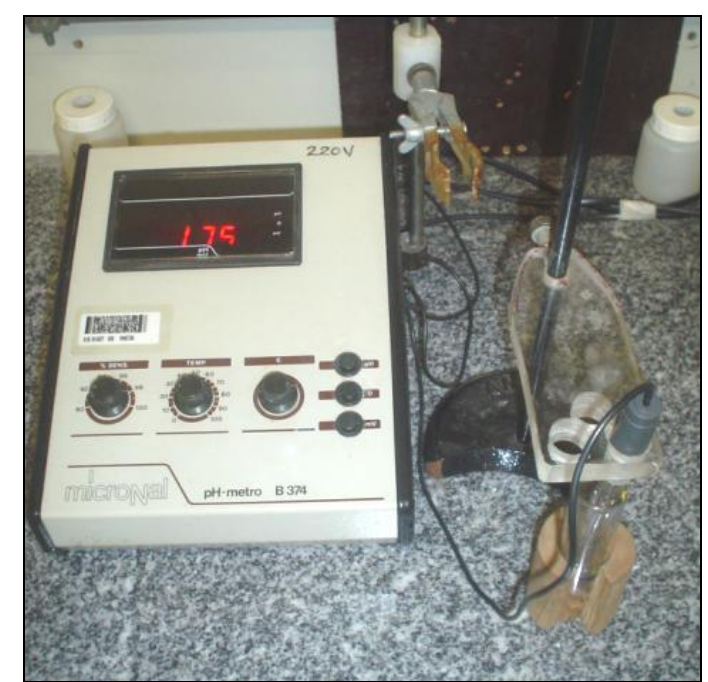

(a)

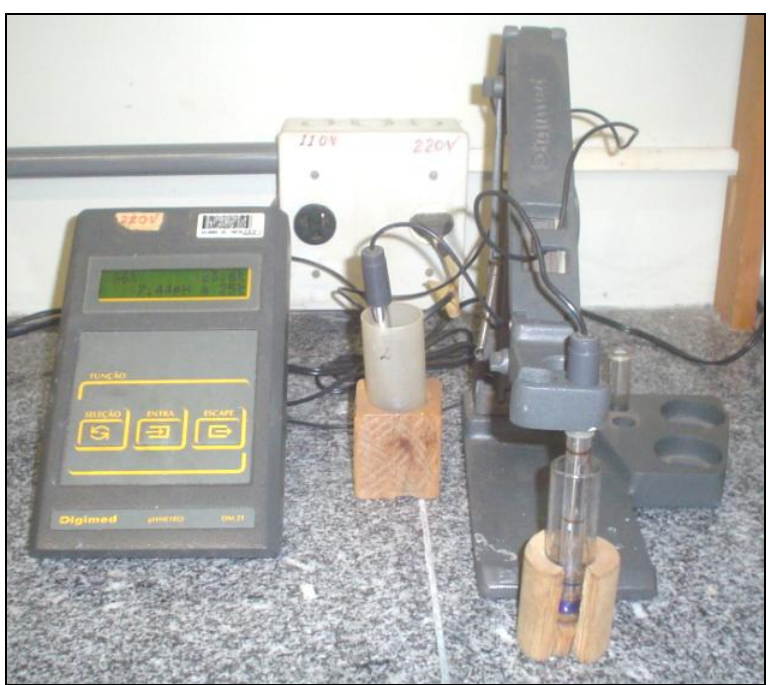

(b) 


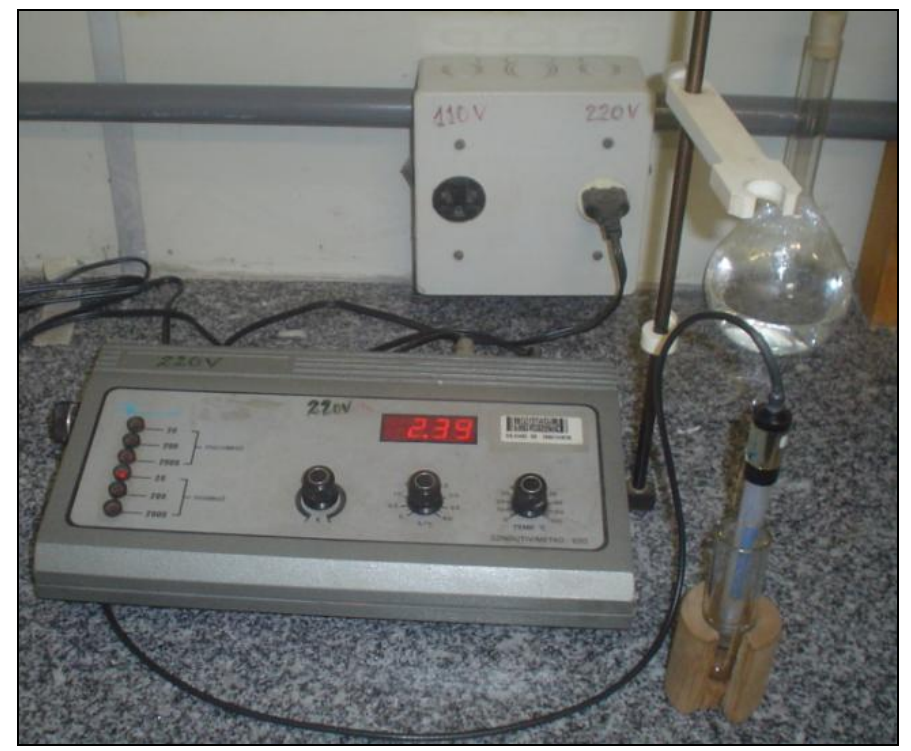

(C)

Figura 3.12 - Equipamentos para análises químicas: (a) Eh; (b) pH; (c) $\mathrm{CE}$

\subsubsection{Extração de solução dos corpos-de-prova}

Após a finalização dos ensaios, os corpos-de-prova foram extraídos e o solo foi fatiado em duas camadas, de maneira que a quantidade de solução extraída fosse suficiente para realizar as análises químicas.

O método utilizado na extração de solução dos corpos-de-prova foi o mesmo utilizado por Musso (2008). Esse método foi proposto por diversos autores como Boscov et al. (1999), Ritter et al. (1999) entre outros, e consiste em aplicar pressão, simulando um processo de adensamento acelerado, com auxílio de macaco hidráulico em pressões de até $25 \mathrm{MPa}$. O sistema construído para a extração consistiu e um êmbolo e uma câmara de PVC conectada a uma seringa para a coleta de líquido. O embolo foi encamisado com um o-ring na extremidade a fim de garantir total contato na entrada na câmara evitando vazamento pela superfície do aparato. Este sistema foi montado num pórtico de reação, onde a pressão foi aplicada através de um macaco hidráulico (Figura 3.13). A pressão aplicada foi transferida a uma célula de carga montada ao pórtico onde possibilitou o controle de aplicação das cargas. O processo durava em torno de 8 horas para cada camada extraída, divididos em três estágios de carregamento com $5 \mathrm{MPa}, 10 \mathrm{MPa}$ e $15 \mathrm{MPa}$. Sendo os dois primeiros com duração de 2 horas e o ultimo carregamento com duração de 4 horas. Desse modo, foi possível coletar cerca de 7 a 13 mL de solução, volume suficiente para as análises químicas. 


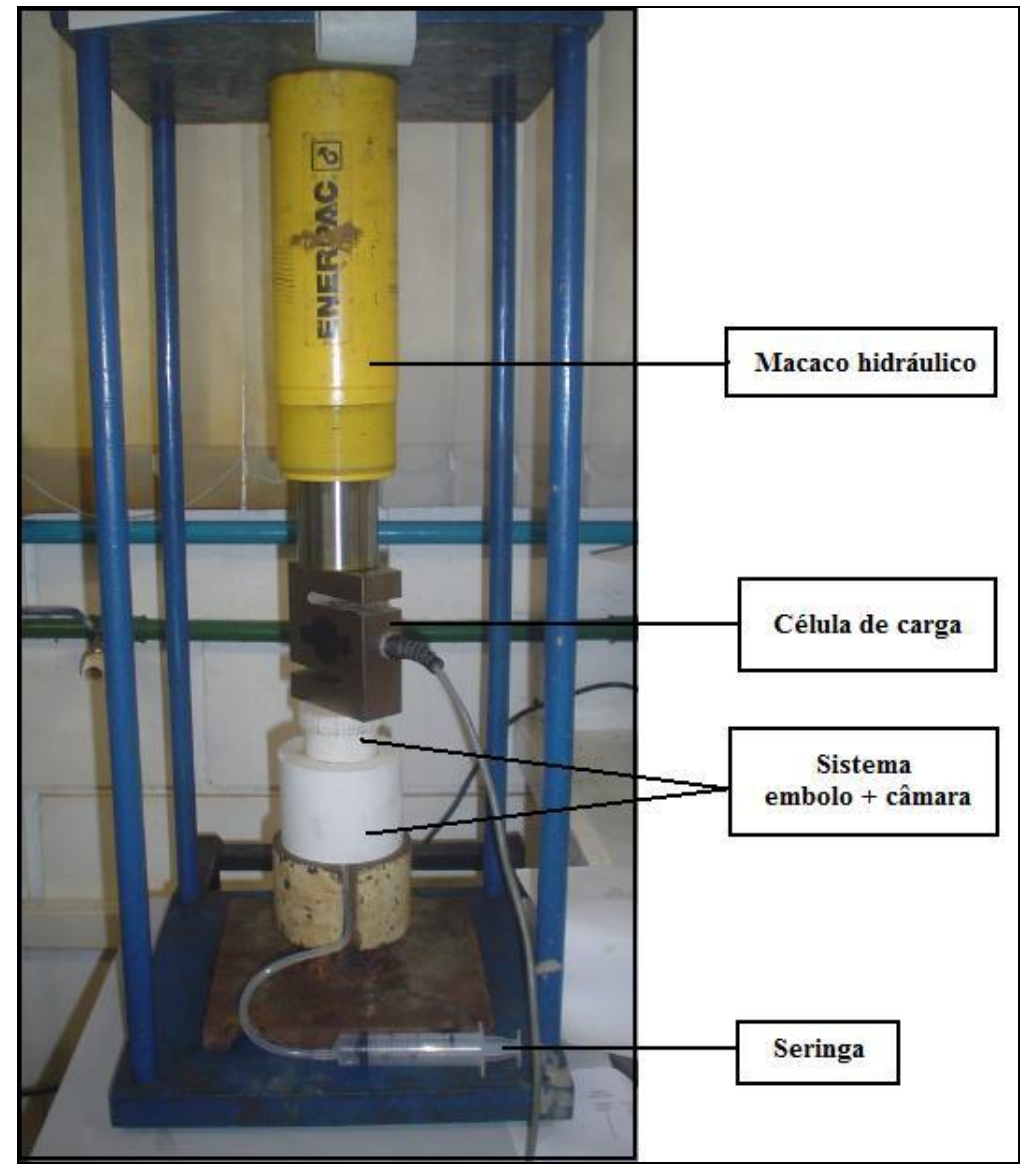

Figura 3.13 - Sistema de extração com pórtico de reação, macaco hidráulico, célula de carga, sistema embolo + câmara e seringa. 


\section{RESULTADOS}

\subsection{Caracterização do material}

Os resultados de caracterização geotécnica dos materiais estudados realizados por Musso (2008) são apresentados na Tabela 4.1. Observa-se que a amostra de solo é predominantemente argilosa, fato que influencia diretamente no comportamento hidráulico do material apresentando valores de $K$ da ordem de $10^{-10}$ a $10^{-11} \mathrm{~m} / \mathrm{s}$ nos ensaios realizados com a amostra compactada.

Tabela 4.1 - Caracterização física da amostra de solo e do GCL.

\begin{tabular}{|c|c|c|c|c|c|c|c|c|c|}
\hline \multirow{2}{*}{ Amostra } & \multicolumn{3}{|c|}{ Granulometria } & \multirow{2}{*}{$\begin{array}{c}\rho_{\mathrm{s}} \\
\left(\mathrm{g} / \mathrm{cm}^{3}\right)\end{array}$} & \multirow{2}{*}{$\begin{array}{l}\text { LL } \\
(\%)\end{array}$} & \multirow{2}{*}{$\begin{array}{l}\text { IP } \\
(\%)\end{array}$} & \multirow{2}{*}{$\begin{array}{c}\text { Classificação } \\
\text { SUCS }\end{array}$} & \multirow{2}{*}{$\begin{array}{c}\gamma_{\mathrm{d}} \\
\left(\mathrm{kN} / \mathrm{cm}^{3}\right)\end{array}$} & \multirow{2}{*}{$\begin{array}{l}\mathrm{W}_{\text {ót }} \\
(\%)\end{array}$} \\
\hline & areia & silte & argila & & & & & & \\
\hline Solo & 15 & 31 & 54 & 3,11 & 74 & 32 & $\mathrm{MH}$ & 15,1 & 24,0 \\
\hline $\begin{array}{c}\text { Bentonita } \\
\text { (GCL) }\end{array}$ & - & $30 *$ & $70 *$ & - & $490 *$ & $432 *$ & - & - & - \\
\hline
\end{tabular}

*Bueno et al (2002).

A Tabela 4.2 apresenta as propriedades físico-químicas dos materiais. A bentonita do GCL apresentou alto valor de CTC. O pH da argila do GCL é básico, e os valores de $\Delta \mathrm{pH}$ dos materiais é negativo, o que indica a predominância de cargas negativas.

Tabela 4.2 - Caracterização físico-química da amostra de solo e do GCL (Musso, 2008) .

\begin{tabular}{cccccc}
\hline Amostra & $\begin{array}{l}\mathrm{CTC}_{\text {solo }} \\
(\mathrm{cmol} / \mathrm{kg})\end{array}$ & $\begin{array}{l}\mathrm{CTC}_{\text {argila }} \\
(\mathrm{cmol} / \mathrm{kg})\end{array}$ & $\mathrm{pH} \mathrm{H} \mathrm{H}_{2} \mathrm{O}$ & $\mathrm{pH} \mathrm{KCl}$ & $\Delta \mathrm{pH}=\mathrm{pH} \mathrm{KCl}-\mathrm{pH} \mathrm{H} \mathrm{H}_{2} \mathrm{O}$ \\
\hline Solo & 21 & 38 & 5,5 & 3,75 & $-1,75$ \\
Bentonita GCL & 91 & 130 & $10,45^{*}$ & $9,31^{*}$ & $-1,14$ \\
\hline CTCsolo - Capacidade de troca de cátions do solo; CTCarg - Capacidade de troca de cátions \\
da fração argila. * razão solo-solução de 1:20
\end{tabular}


Os ensaios de ATD realizados na amostra de solo identificaram a presença de mistura de ilita e caulinita e provavelmente uma pequena quantidade de esmectita. A argila do GCL é composta basicamente por quartzo e esmectita sódica, o que confirma o valor de CTC quatro vezes maior que o da amostra de solo.

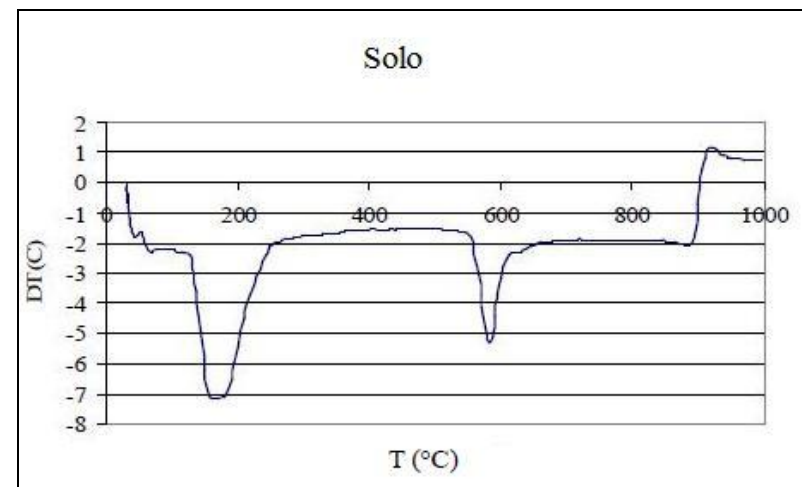

(a)

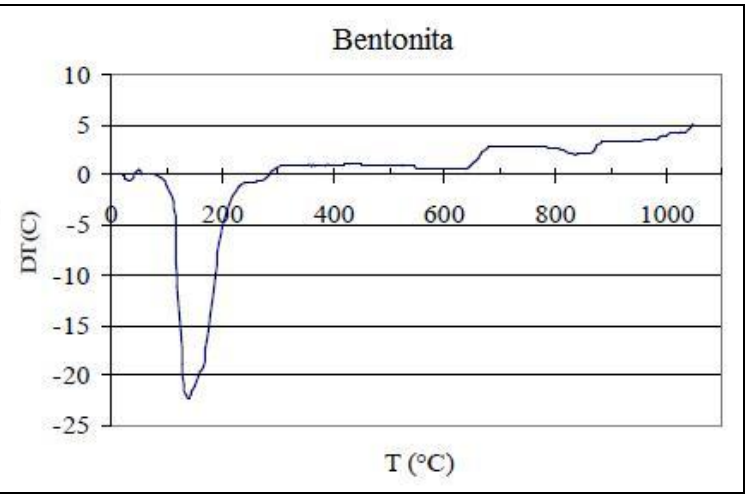

(b)

Figura 4.1 - (a) ATD da amostra de solo; (b) ATD da bentonita do GCL (Musso, 2008).

Os ensaio de difração de Raio X realizados por Marques (2009) estão apresentados na Figura 4.2. No difratograma da amostra de solo observa-se um pico aberto entre $8^{\circ}$ a $8,5^{\circ}$, o que corresponde a ilita. Em aproximadamente $17,5^{\circ}$ verifica-se a presença de esmectita e possivelmente caulinita, e em $26,5^{\circ} \mathrm{com}$ pico mais intenso a presença de quartzo. No difratograma da bentonita do GCL verifica-se um pico intenso entre $7,35^{\circ}$ a $8^{\circ}$ o que corresponde a presença de esmectita sódica, e em $21^{\circ}$ a $26,8^{\circ}$ a presença do quartzo.

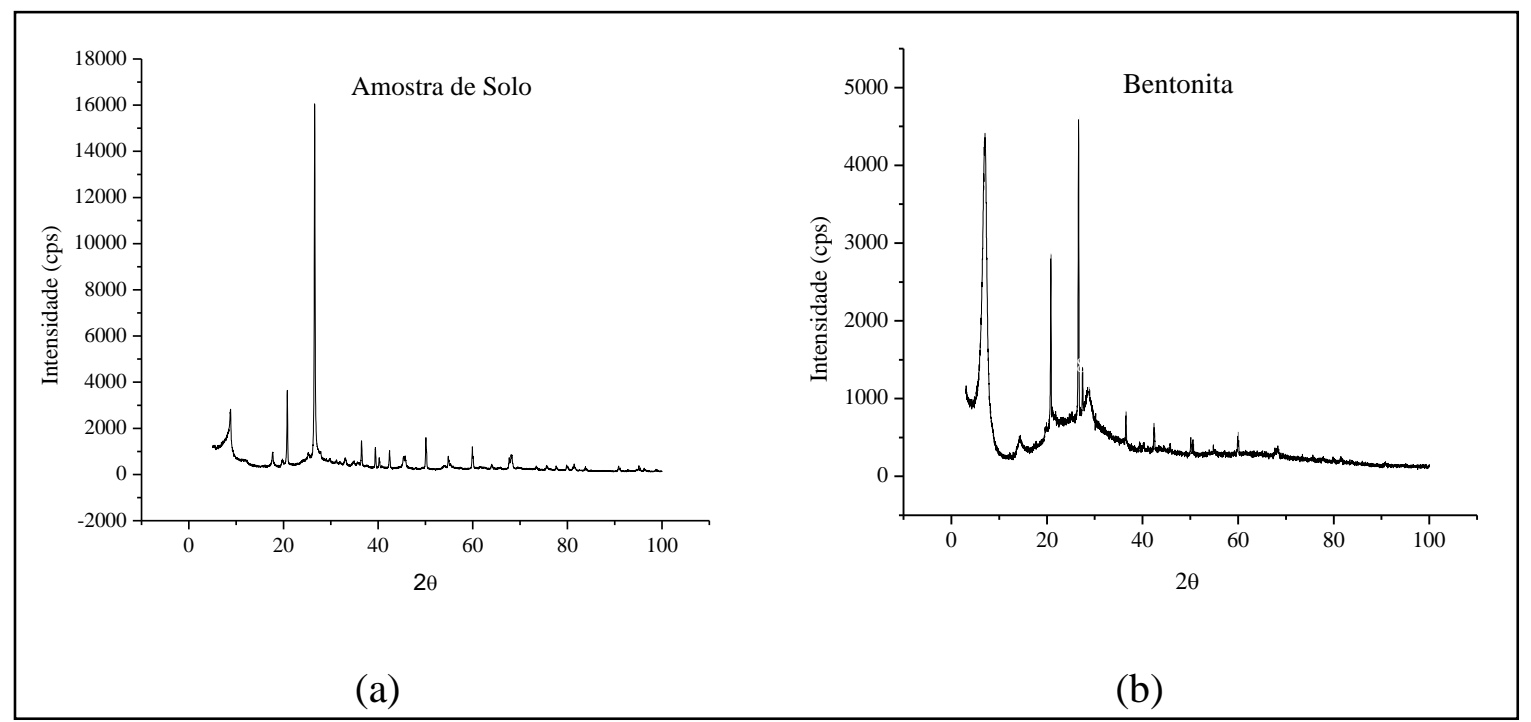

Figura 4.2 - (a) Difração de Raio X da amostra de solo; (b) Difração em Raio X da bentonita do GCL (Marques, 2009). 


\subsection{Ensaio em coluna}

Os resultados apresentados referem-se à condutividade hidráulica, $\mathrm{pH}$, condutividade elétrica e Eh obtidos durante a fase de percolação com água destilada/deionizada e com solução contaminante de $\mathrm{KCl}$ na concentração de $0,023 \mathrm{M}$ para os dois corpos-de-prova ensaiados. A Tabela 4.3 apresenta as características dos corpos-de-prova ensaiados.

Tabela 4.3 - Características dos corpos-de-prova e dos ensaios em coluna.

\begin{tabular}{|c|c|c|c|c|}
\hline \multirow{2}{*}{ Dados } & \multicolumn{2}{|c|}{ CP - 1} & \multicolumn{2}{|c|}{ CP - 2} \\
\hline & Solo & GCL & Solo & GCL \\
\hline Área $\left(\mathrm{cm}^{2}\right)$ & 69,39 & 69,39 & 69,39 & 69,39 \\
\hline Diâmetro (cm) & 9,4 & 9,4 & 9,4 & 9,4 \\
\hline Altura no CP (cm) & 1,35 & 0,8 & 1,35 & 0,8 \\
\hline Altura do GCL (cm) & - & $0,6^{*}$ & - & $0,6^{*}$ \\
\hline$\rho_{\mathrm{d}}\left(\mathrm{g} / \mathrm{cm}^{3}\right)$ & 1,51 & 0,99 & 1,50 & 1,08 \\
\hline$n$ & 0,52 & 0,64 & 0,52 & 0,61 \\
\hline $\mathrm{W}_{\text {ót }}(\%)$ & 23,52 & - & 23,52 & - \\
\hline Wnatural (\%) & 6,26 & 13,09 & 6,26 & 13,09 \\
\hline Volume de vazios $\left(\mathrm{cm}^{3}\right)$ & 48,2 & 26,64 & 48,2 & 25,39 \\
\hline Volume de vazios total $\left(\mathrm{cm}^{3}\right)$ & \multicolumn{2}{|c|}{74,84} & \multicolumn{2}{|c|}{73,59} \\
\hline Tempo de ensaio (dias) & \multicolumn{2}{|c|}{390} & \multicolumn{2}{|c|}{352} \\
\hline$K_{\text {final }}(\mathrm{m} / \mathrm{s})$ & \multicolumn{2}{|c|}{$3,41 \times 10^{-11}$} & \multicolumn{2}{|c|}{$7,79 \times 10^{-11}$} \\
\hline Carga hidráulica (kPa) & \multicolumn{2}{|c|}{150} & \multicolumn{2}{|c|}{100} \\
\hline Gradiente hidráulico & \multicolumn{2}{|c|}{698} & \multicolumn{2}{|c|}{465} \\
\hline Molaridade de $\mathrm{KCl}(\mathrm{M})$ & \multicolumn{2}{|c|}{0,023} & \multicolumn{2}{|c|}{0,023} \\
\hline Concentração de $\mathrm{KCl}(\mathrm{mg} / \mathrm{L})$ & \multicolumn{2}{|c|}{1713,5} & \multicolumn{2}{|c|}{1713,5} \\
\hline
\end{tabular}

*Altura considerada para o cálculo do volume de vazios do GCL, com desconto de $0,2 \mathrm{~cm}$ correspondente à altura dos geotexteis que formam o geocomposto bentonítico.

A condutividade hidráulica foi calculada a partir da equação de Darcy. Porém, um dos fatores que afeta diretamente a condutividade hidráulica de um solo são as características do líquido percolante, como o peso específico e a viscosidade da água. Estes fatores variam em função da temperatura, sendo que o mais afetado é a viscosidade (Basso, 2003). Portanto, neste trabalho apresenta-se a condutividade hidráulica á uma temperatura de referência de $20^{\circ} \mathrm{C}$, para padronizar a o efeito da variação da viscosidade. Este cálculo é expresso através da equação:

$$
K_{20}=\frac{\mu_{T}}{\mu_{20}} K_{T}
$$


Onde $\mathrm{K}_{20}$ é a condutividade hidráulica a $20^{\circ} \mathrm{C}, \mathrm{K}_{\mathrm{T}}$ a condutividade hidráulica a temperatura mensurada em ${ }^{\circ} \mathrm{C}, \mu_{\mathrm{T}}$ é a viscosidade da água e $\mathrm{T}$ em $\mathrm{C}^{\mathrm{o}} ; \mu_{20}$ é a viscosidade da água a $20^{\circ} \mathrm{C}$.

As Figuras 4.4 e 4.5 apresentam o comportamento da condutividade hidráulica em m/s do ensaio realizado no $\mathrm{CP}-1$ (GCL acima da camada de solo compactado) com relação ao volume de vazios percolados e ao tempo em dias.

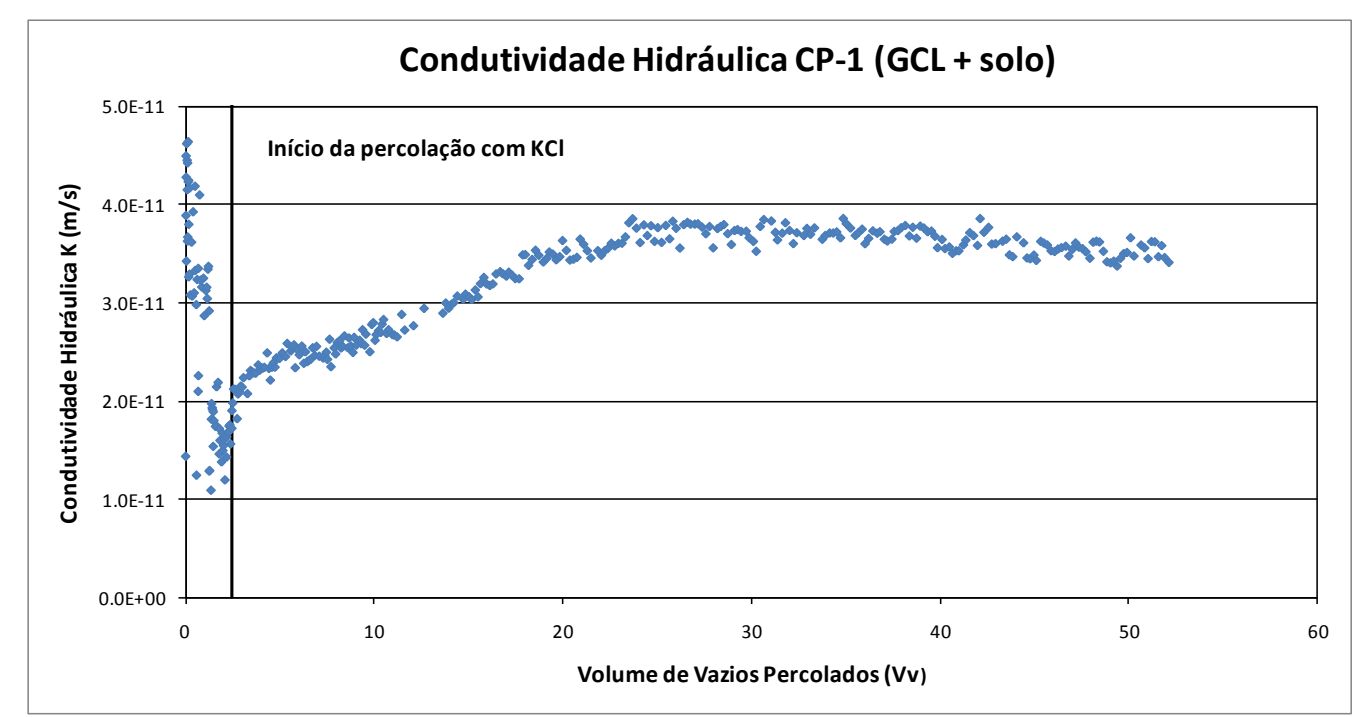

Figura 4.4 - Curva de variação da condutividade hidráulica em função do $\mathrm{n}^{\circ}$ de volume de vazios percolados durante as fases de saturação e percolação com solução de $\mathrm{KCl}$ do ensaio CP - 1 .

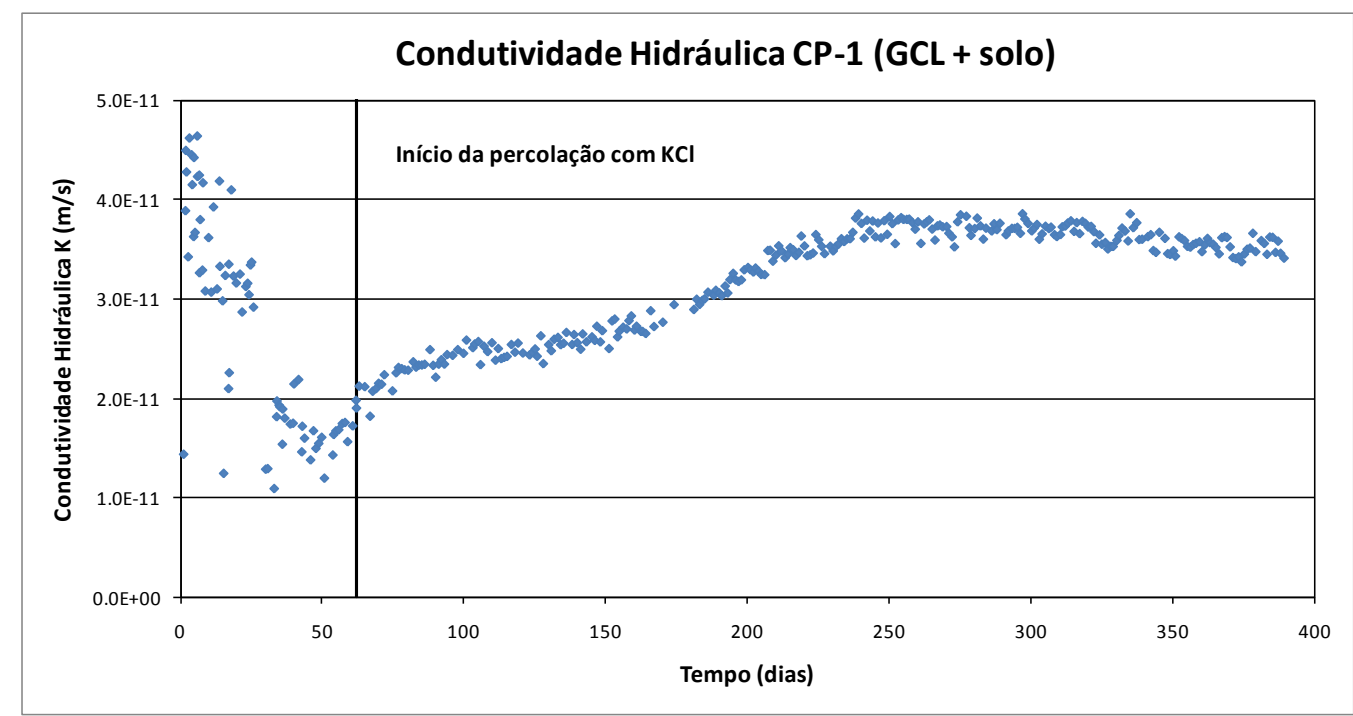

Figura 4.5 - Curva de variação da condutividade hidráulica em função do tempo em dias durante as fases de saturação e percolação com solução de $\mathrm{KCl}$. 
As Figuras 4.6 e 4.7 apresentam o comportamento da condutividade hidráulica em m/s do ensaio realizado no $\mathrm{CP}-2$ (camada de solo compactado acima do GCL) com relação ao volume de vazios percolados e ao tempo em dias.

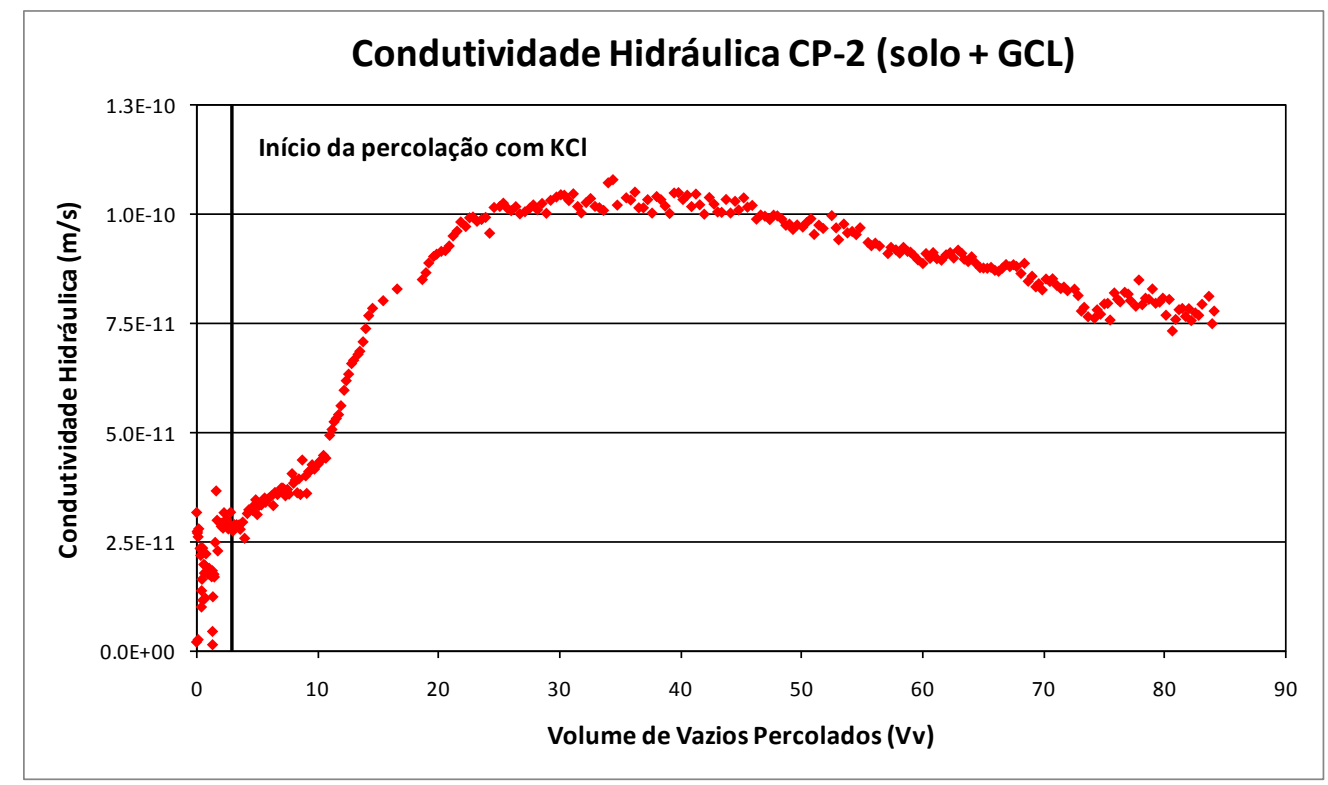

Figura 4.6 - Curva de variação da condutividade hidráulica em função do $\mathrm{n}^{\mathrm{o}}$ de volume de vazios percolados durante as fases de saturação e percolação com solução de $\mathrm{KCl}$ do ensaio CP - 2.

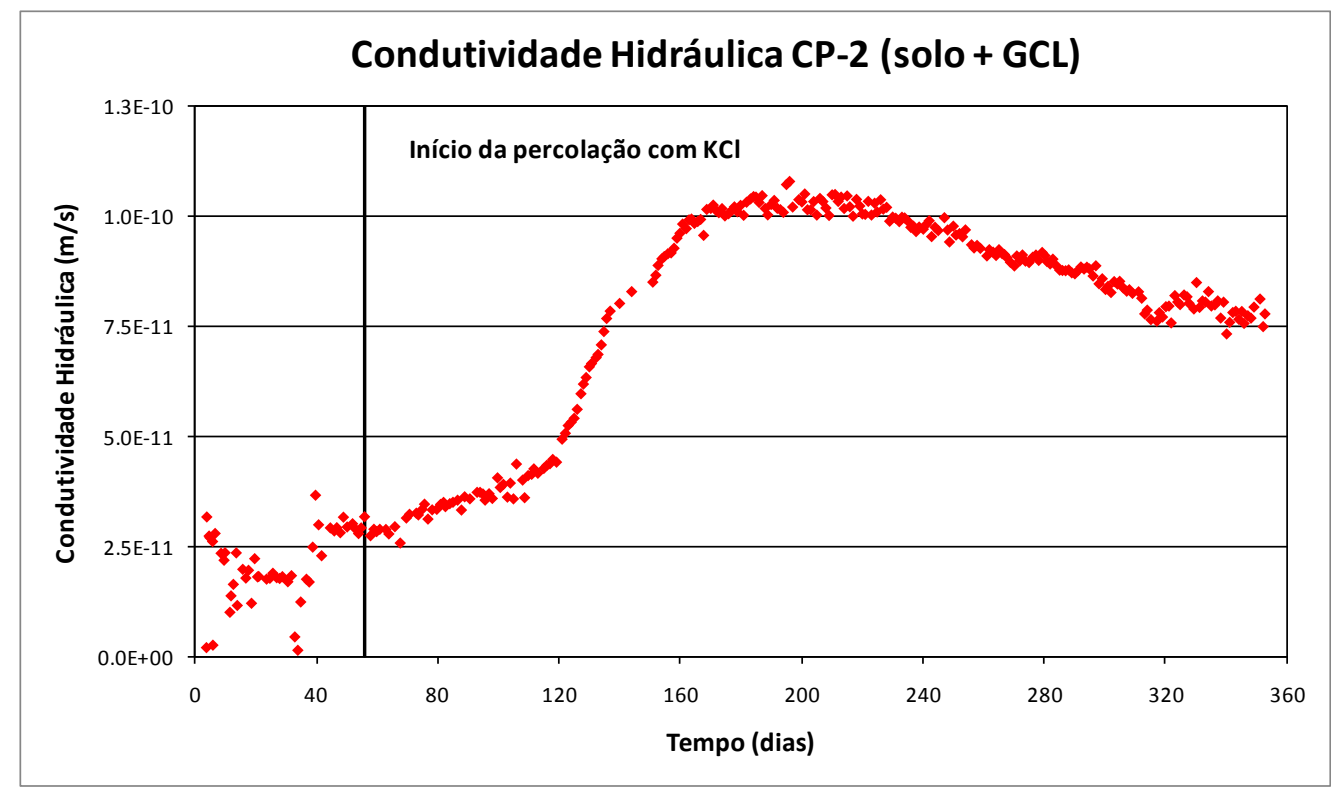

Figura 4.7 - Curva de variação da condutividade hidráulica em função do tempo em dias durante as fases de saturação e percolação com solução de $\mathrm{KCl}$ do ensaio $\mathrm{CP}$ - 2 . 
Foram plotados também os valores de $\mathrm{Na}^{+}$em função do volume de poros percolados para ambos os ensaios. As curvas de variação estão apresentadas nas Figuras 4.8 e 4.9.

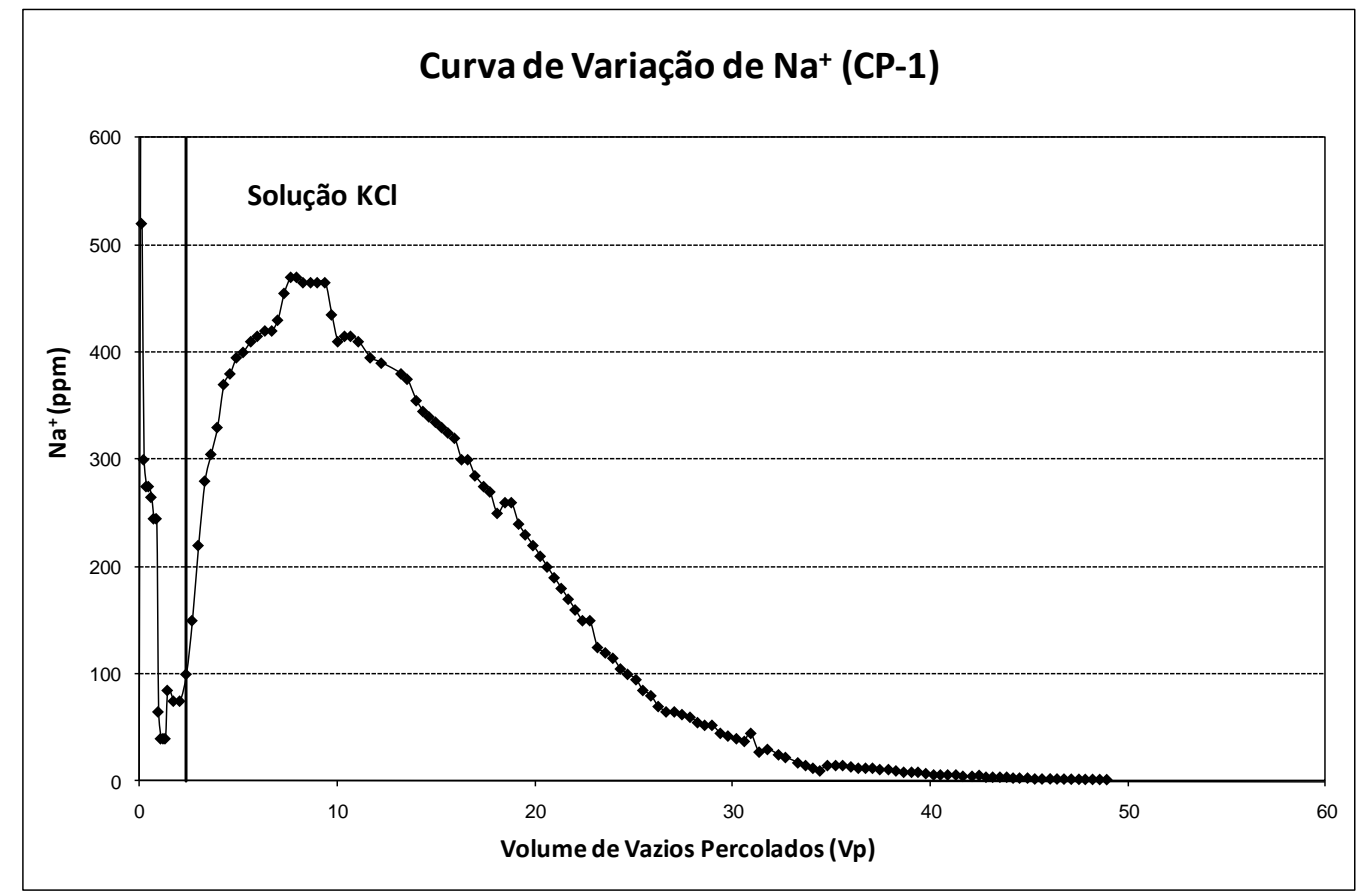

Figura 4.8 - Curva de variação do $\mathrm{Na}^{+}$em função do $\mathrm{n}^{\mathrm{o}}$ de volume de vazios percolados durante as fases de saturação e percolação com solução de $\mathrm{KCl}$ do ensaio $\mathrm{CP}$ - 1 .

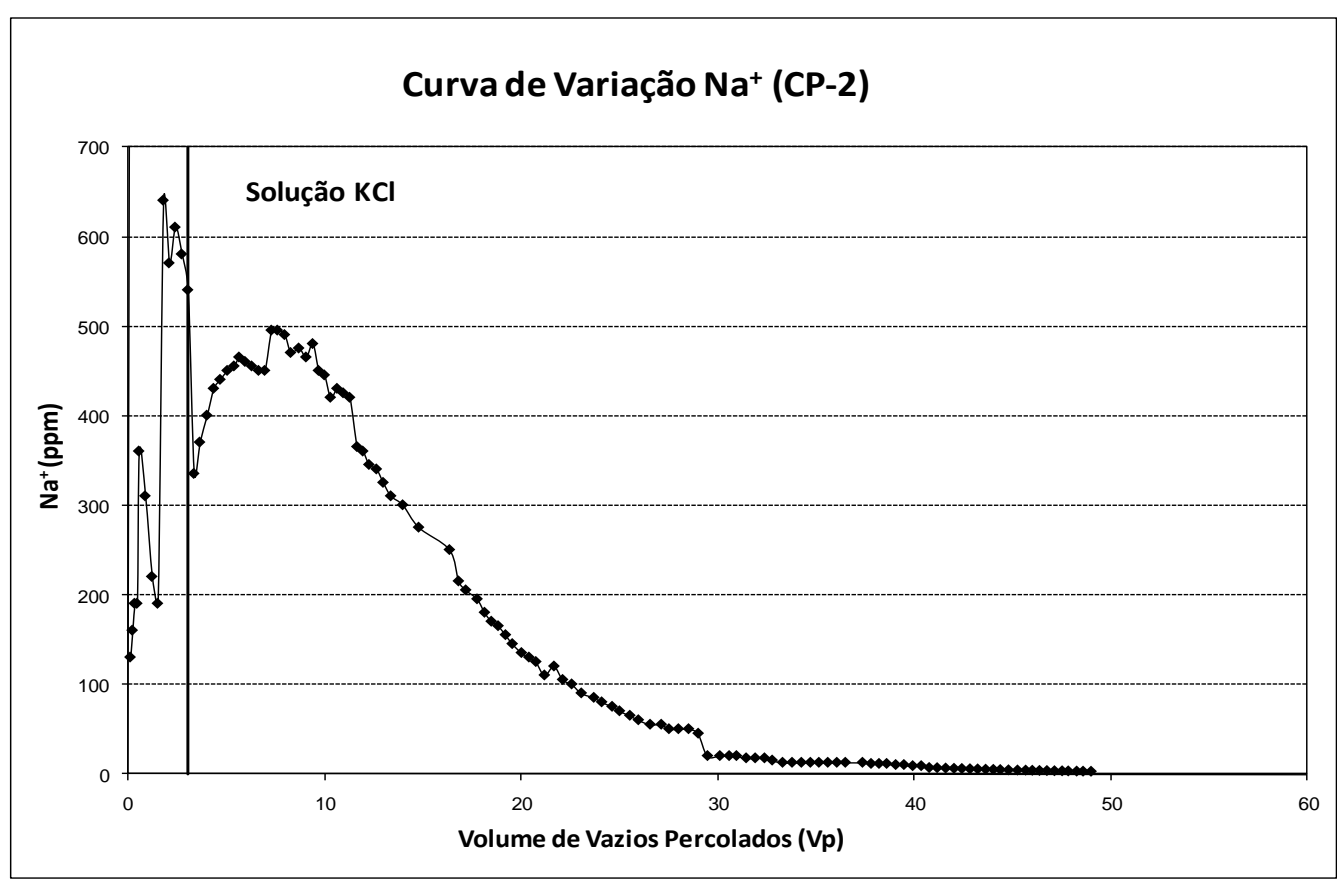

Figura 4.9 - Curva de variação do $\mathrm{Na}^{+}$em função do $\mathrm{n}^{\circ}$ de volume de vazios percolados durante as fases de saturação e percolação com solução de $\mathrm{KCl}$ do ensaio CP - 2 . 


\subsection{1 $\mathrm{pH}$ (potencial hidrogeniônico)}

A determinação do $\mathrm{pH}$ possibilitou obter as curvas em função do volume de vazios percolados do efluente, como apresentado na Figura 4.10 e 4.11.

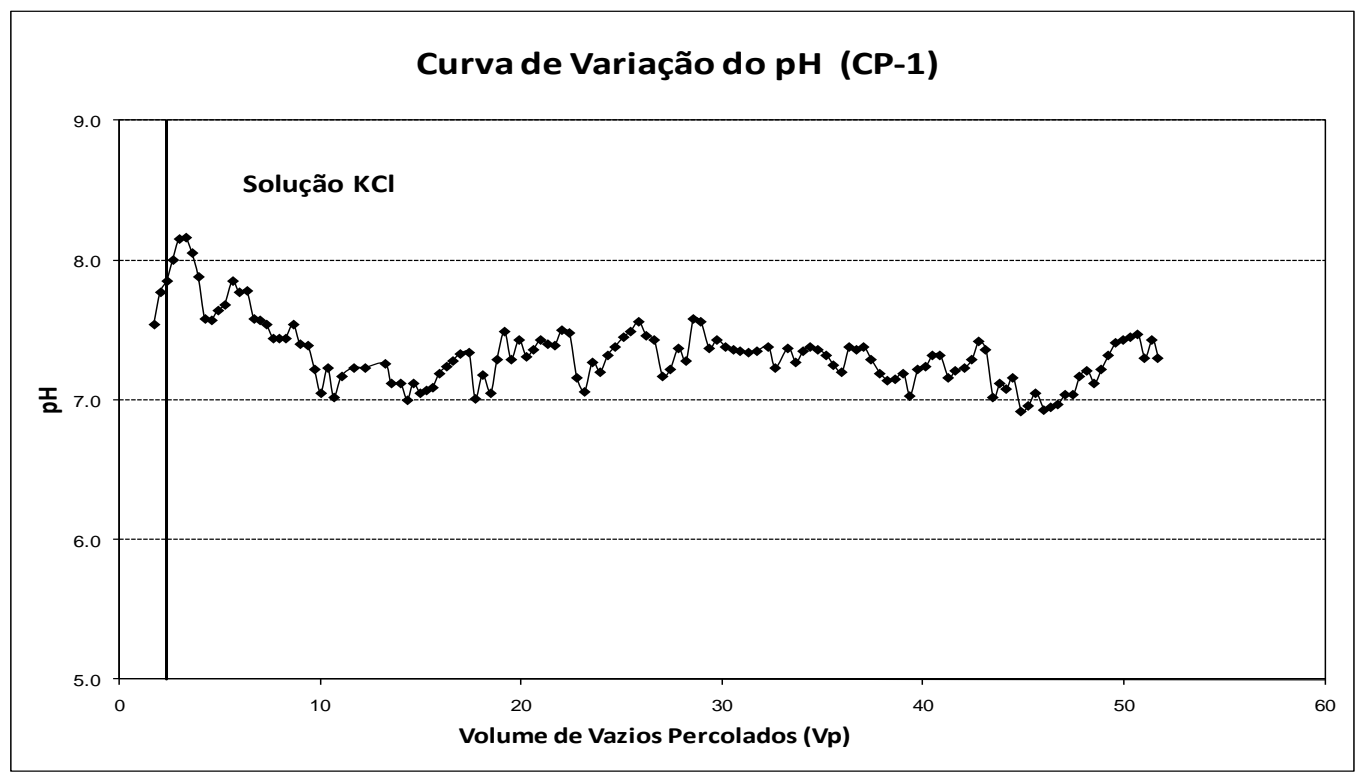

Figura 4.10 - Curva de variação do $\mathrm{pH}$ em função do $\mathrm{n}^{\mathrm{o}}$ de volume de vazios percolados durante as fases de saturação e percolação com solução de $\mathrm{KCl}$ do ensaio $\mathrm{CP}$ - 1 .

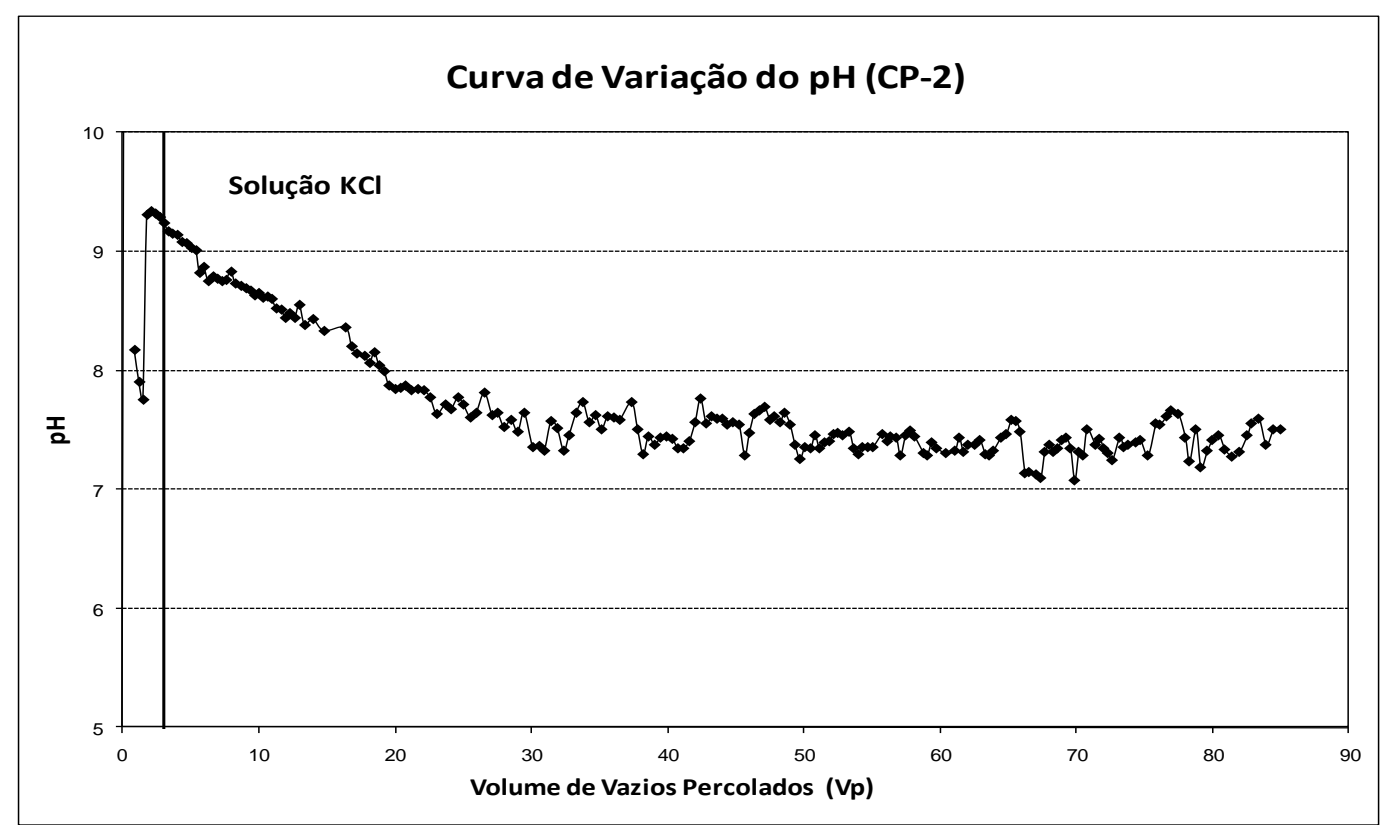

Figura 4.11 - Curva de variação do $\mathrm{pH}$ em função do $\mathrm{n}^{\circ}$ de volume de vazios percolados durante as fases de saturação e percolação com solução de $\mathrm{KCl}$ do ensaio $\mathrm{CP}$ - 2 . 


\subsubsection{Condutividade elétrica}

Os resultados de condutividade elétrica estão apresentados em $\mu \mathrm{mho.cm}{ }^{-1}$ nas Figuras 4.12 e 4.13 em função do volume de vazios percolados.

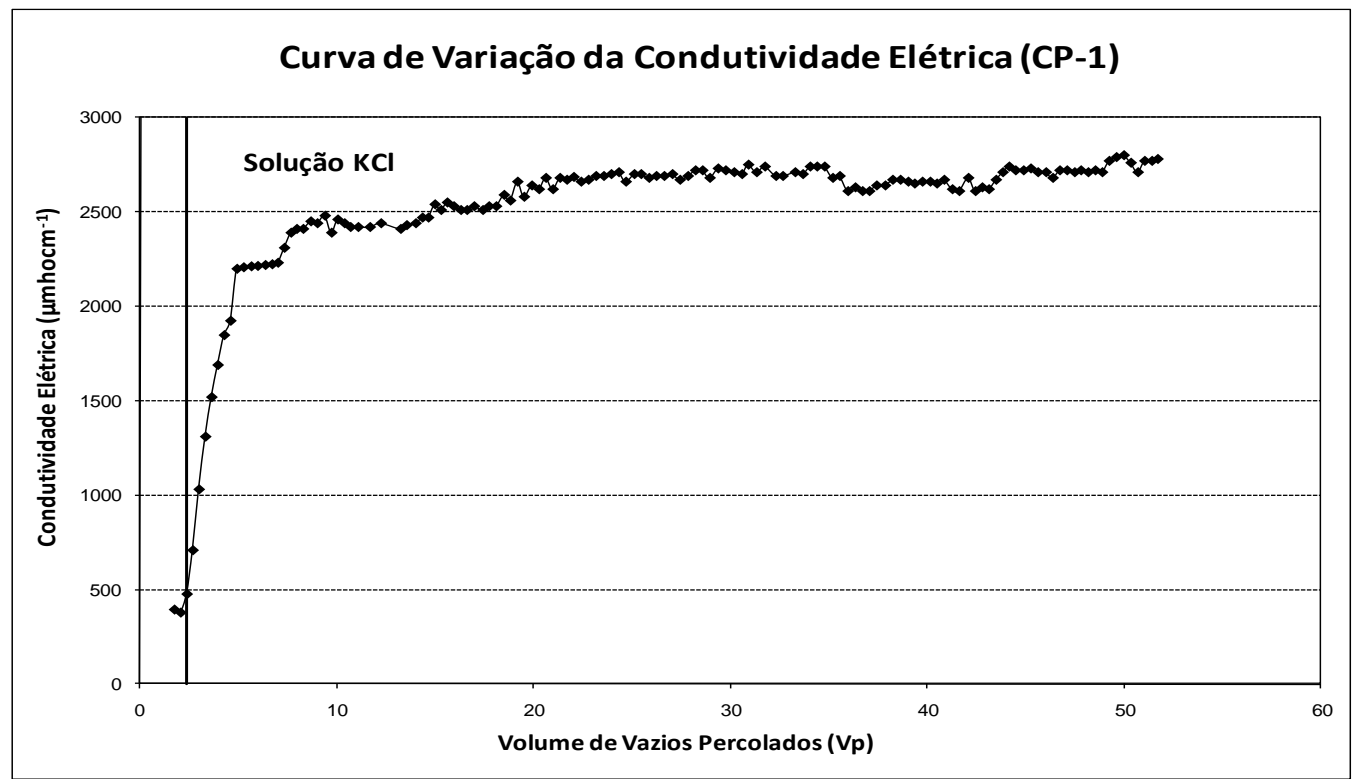

Figura 4.12 - Curva de variação da condutividade elétrica em função do $\mathrm{n}^{\circ}$ de volume de vazios percolados durante as fases de saturação e percolação com solução de $\mathrm{KCl}$ do ensaio $\mathrm{CP}-1$.

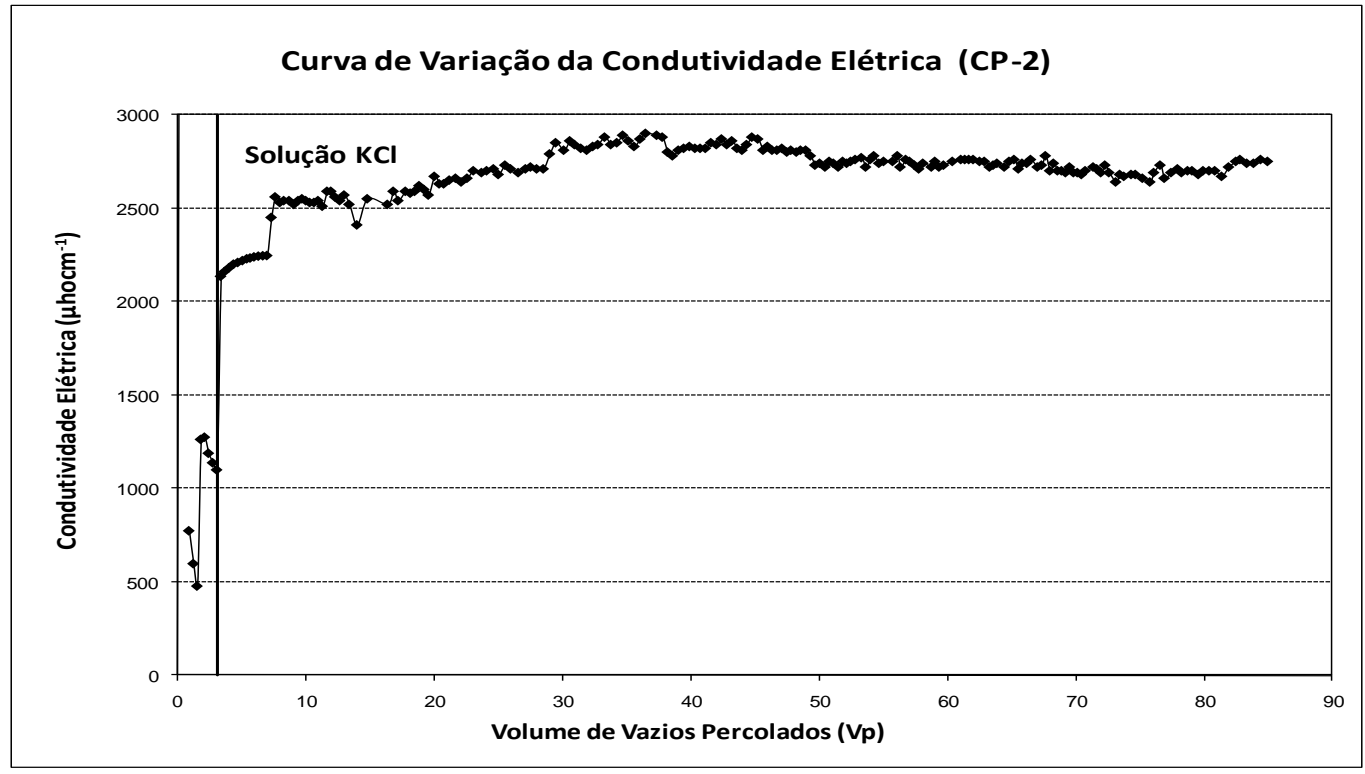

Figura 4.13 - Curva de variação da condutividade elétrica em função do $\mathrm{n}^{\circ}$ de volume de vazios percolados durante as fases de saturação e percolação com solução de $\mathrm{KCl}$ do ensaio $\mathrm{CP}-2$. 


\subsubsection{Potencial de oxi-redução (Eh)}

As Figuras 4.14 e 4.15 apresentam a variação do Eh em função do volume de vazios percolados.

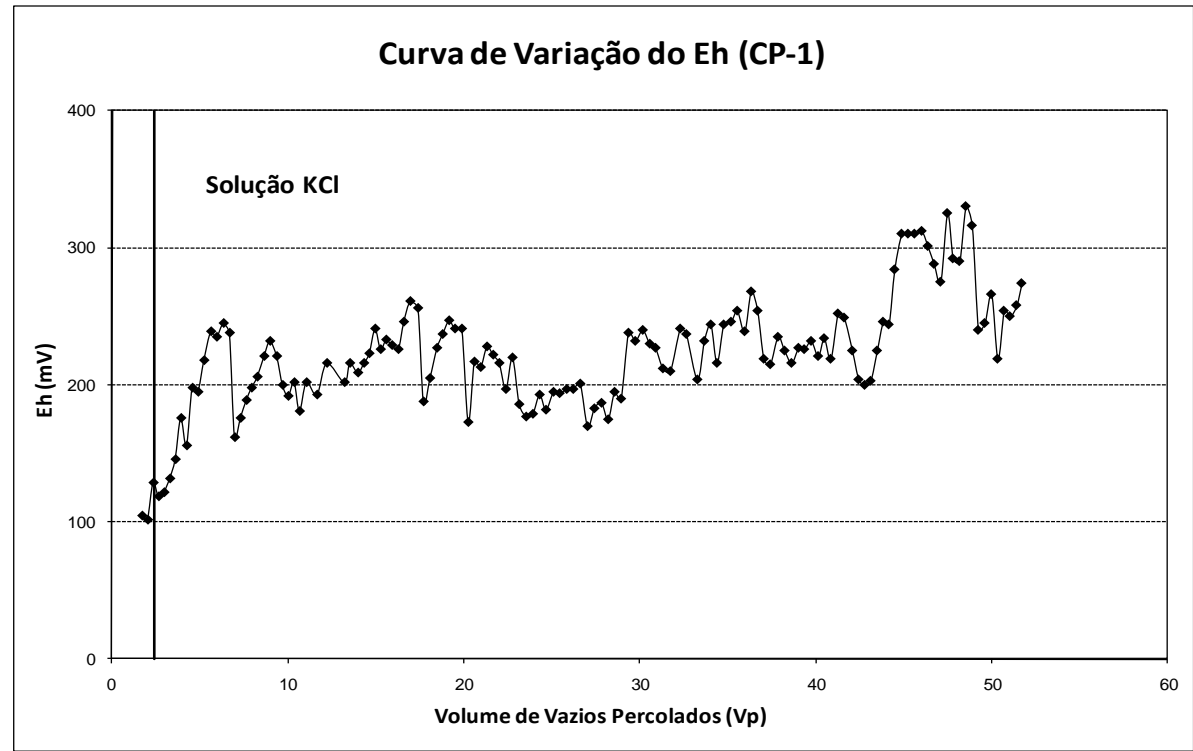

Figura 4.14 - Curva de variação do Eh em função do $\mathrm{n}^{\circ}$ de volume de vazios percolados durante as fases de saturação e percolação com solução com solução de $\mathrm{KCl}$ do ensaio $\mathrm{CP}-1$.

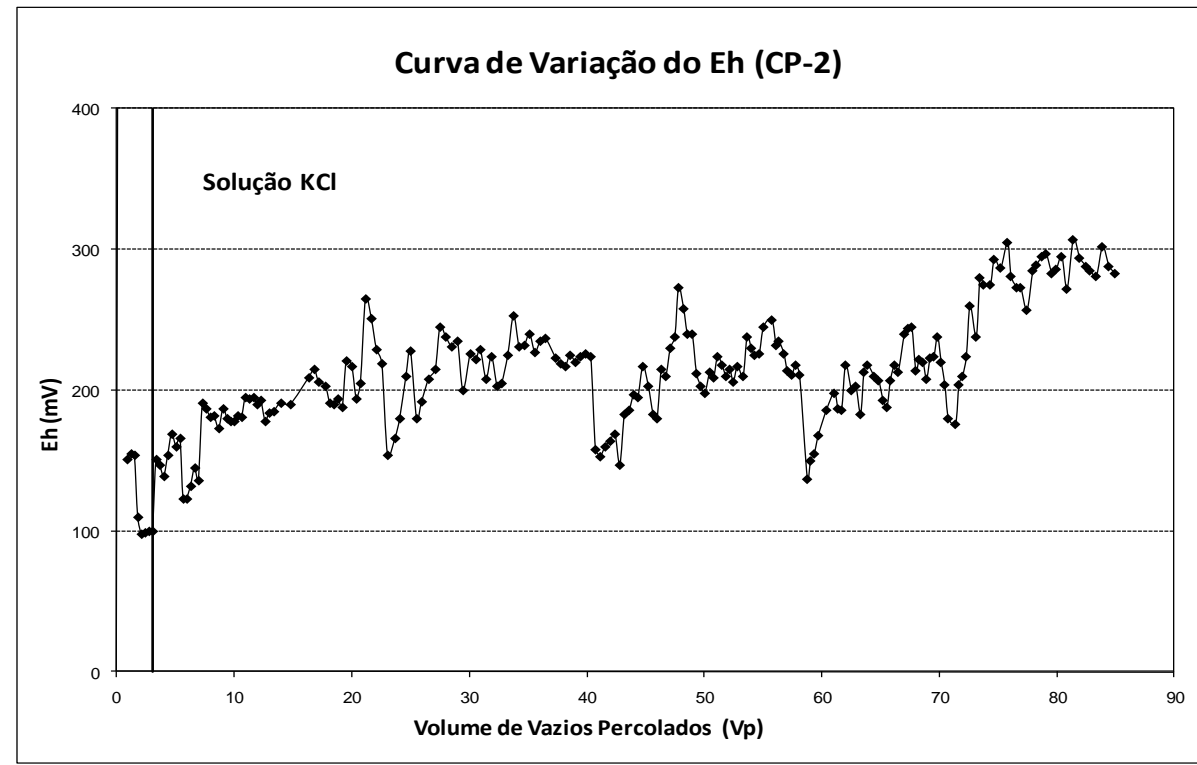

Figura 4.15 - Curva de variação do Eh em função do $\mathrm{n}^{\circ}$ de volume de vazios percolados durante as fases de saturação e percolação com solução com solução de $\mathrm{KCl}$ do ensaio $\mathrm{CP}-2$. 


\subsection{Curvas de chegada}

São apresentados os pontos referentes às curvas de chegada para os íons $\mathrm{K}^{+}$e $\mathrm{Cl}^{-}$para os ensaios $\mathrm{CP}-1$ e $\mathrm{CP}-2$. As curvas foram plotadas em função do número de volume de vazios percolados e dos valores de concentração relativa $\left(\mathrm{C} / \mathrm{C}_{0}\right)$ obtidos no efluente (Figuras 4.16 e 4.17$)$.

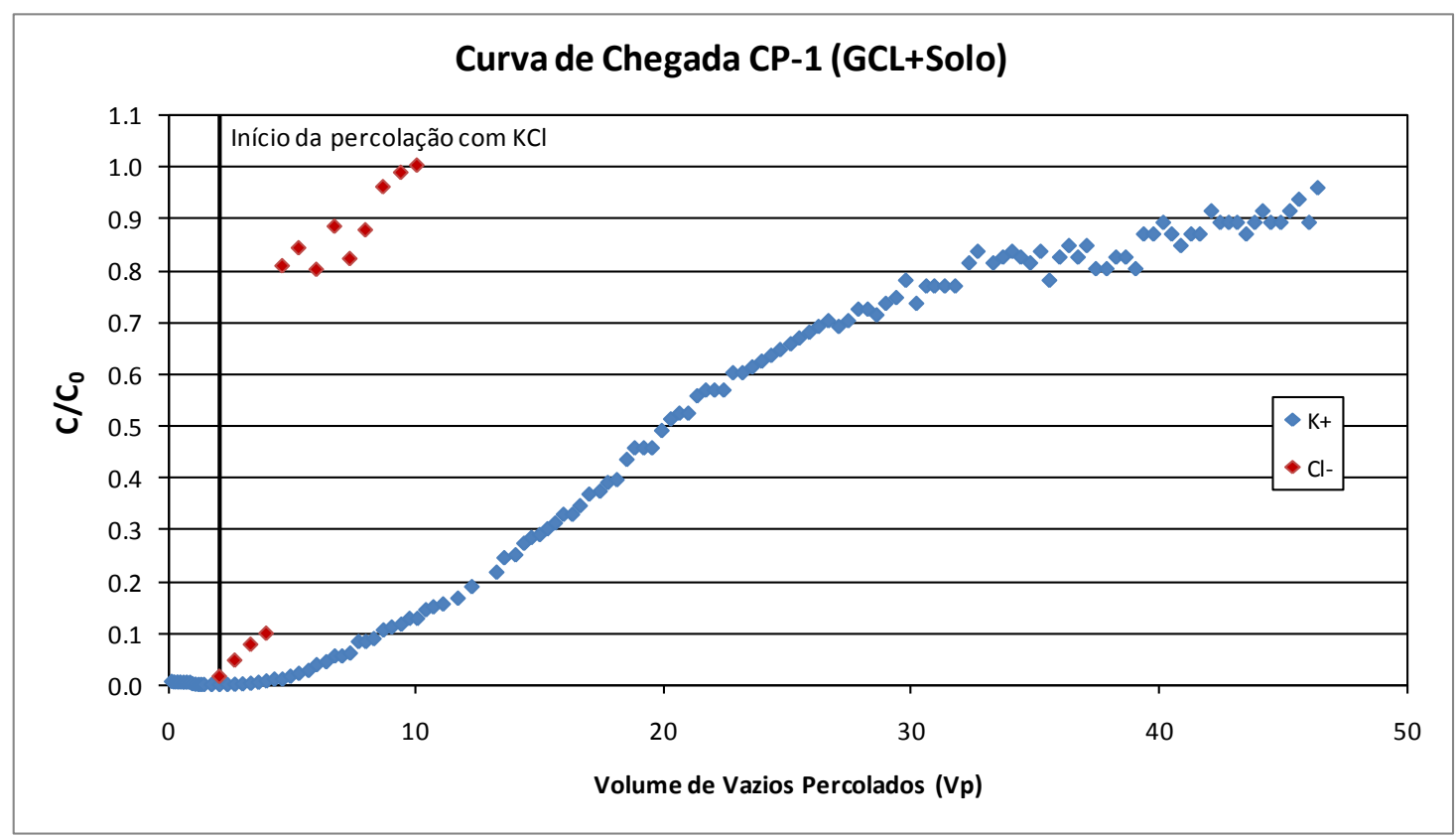

Figura 4.16 - Curva de chegada dos íons $\mathrm{K}^{+}$e $\mathrm{Cl}^{-}$obtidas a partir dos ensaios $\mathrm{CP}-1$.

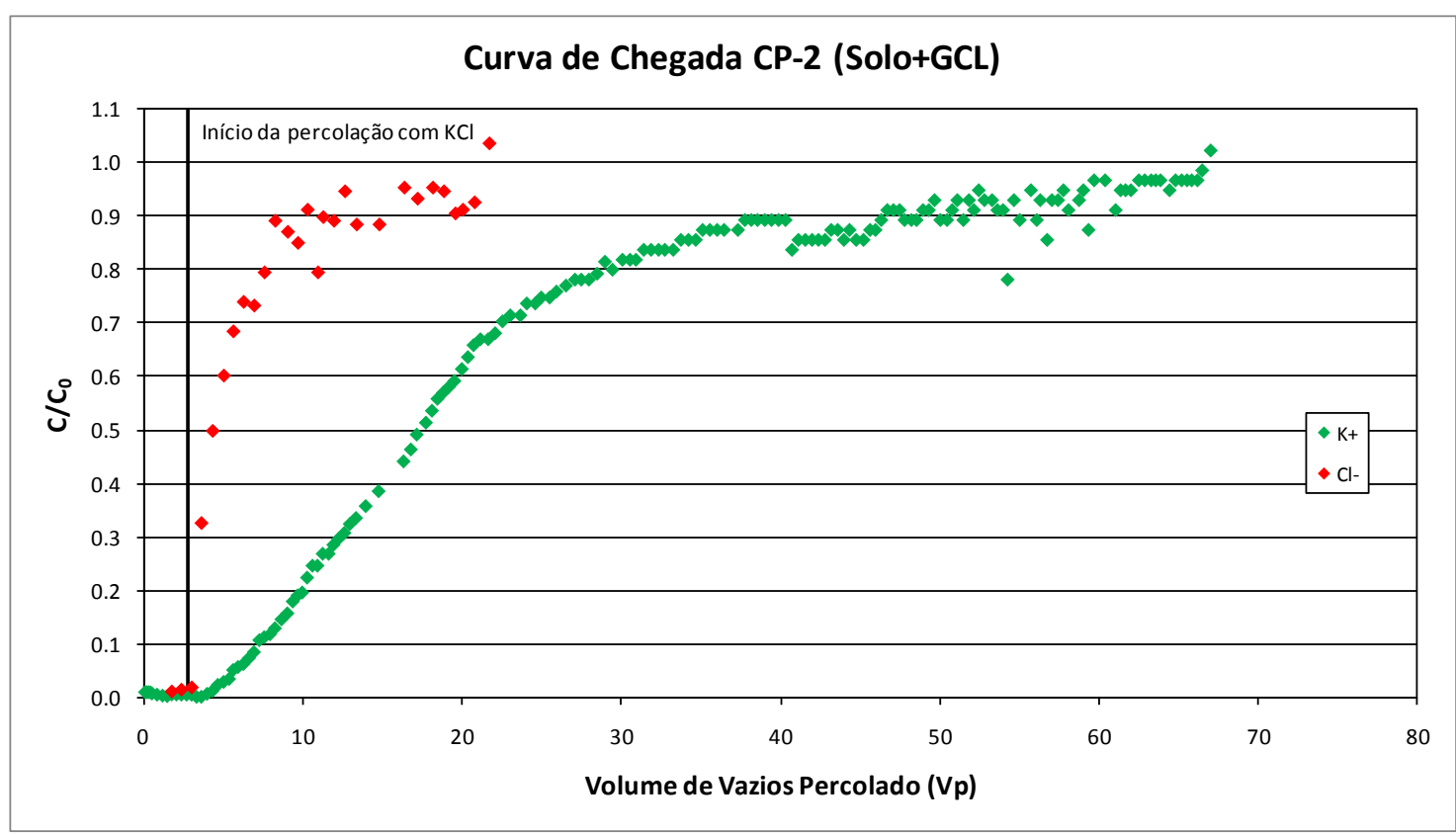

Figura 4.17 - Curva de chegada dos íons $\mathrm{K}^{+} \mathrm{e} \mathrm{Cl}^{-}$obtidas a partir dos ensaios $\mathrm{CP}-2$. 


\section{ANÁLISE DOS RESULTADOS}

\subsection{Condutividade Hidráulica}

A condutividade hidráulica foi analisada por partes, ou seja, por trechos de volume de vazios percolados e por tempo, nas fases de percolação com água destilada/deionizada para saturação e na fase de percolação com solução contaminante.

Como se pode notar, o $\mathrm{CP}-1$ apresentou redução no coeficiente de permeabilidade na fase de percolação com água destilada/deionizada apresentando valores de $5,0 \times 10^{-11} \mathrm{~m} / \mathrm{s}$ reduzidos para $1,2 \times 10^{-11} \mathrm{~m} / \mathrm{s}$. A fase de percolação com solução contaminante de $\mathrm{KCl}$ foi iniciada em aproximadamente 3 volumes de vazios percolados $(\mathrm{Vp})$. No início desta fase a condutividade hidráulica apresentou um leve aumento em seu valor até atingir aproximadamente $10 \mathrm{Vp}$ (correspondendo a 110 dias de ensaio) submetida à pressão de 100 $\mathrm{kPa}$. A partir deste momento, fez-se necessário aumentar a pressão, visto que o tempo do ensaio estava incompatível com o tempo da pesquisa. Portanto, para efeito de aceleração do ensaio aumentou-se a pressão para $150 \mathrm{kPa}$. É possível observar que a partir deste trecho ocorre um acréscimo mais acentuado na condutividade hidráulica até atingir $23 \mathrm{Vp}$ (235 dias de ensaio). Depois deste ponto a condutividade hidráulica apresenta um comportamento estável, com valores da ordem de 3,5 a $3,8 \times 10^{-11} \mathrm{~m} / \mathrm{s}$. Este comportamento estável ocorre por $20 \mathrm{Vp}$ (100 dias de ensaio), e depois sofre um decréscimo atingindo o equilíbrio novamente com valores de condutividade hidráulica de $3,5 \times 10^{-11} \mathrm{~m} / \mathrm{s}$.

Percebe-se que o $K$ manteve-se estável a partir de um determinado volume de vazios percolados, apresentando comportamento hidráulico satisfatório e compatível com os valores sugeridos pelas regulamentações para o uso como barreira impermeabilizante. 
$\mathrm{O}$ ensaio realizado com a configuração do $\mathrm{CP}-2$ apresentou variação quando comparado com ensaio $\mathrm{CP}-1$. É possível verificar este comportamento na fase de percolação com água destilada/deionizada, quando o $K$ apresenta valores dispersos. Mesmo assim, diferente do ensaio CP - 1, nesta fase o $K$ sofreu um acréscimo de $1,5 \times 10^{-11} \mathrm{~m} / \mathrm{s}$ para $2,6 \times 10^{-11} \mathrm{~m} / \mathrm{s}$ até percolar $2,84 \mathrm{Vp}$ (56 dias de ensaio). Após este momento iniciou-se a fase de percolação com solução contaminante na pressão de $100 \mathrm{kPa}$. A partir desse ponto percebe-se que houve dois trechos de acréscimo de condutividade hidráulica até atingir um comportamento estável. No primeiro trecho o aumento do $K$ foi sensível ao percorrer $7 \mathrm{Vp}$ em 60 dias. No trecho seguinte, com $13 \mathrm{Vp}$, porém um tempo mais curto de 50 dias, a condutividade hidráulica atingiu valores de $1,1 \times 10^{-10} \mathrm{~m} / \mathrm{s}$. Ou seja, sofreu acréscimo em uma ordem de grandeza. Em seguida, os valores $K$ sofrem um decréscimo até atingir valores de $K$ estáveis na ordem de $7,7 \times 10^{-11} \mathrm{~m} / \mathrm{s}$.

Comparando o comportamento dos dois ensaios, o CP - 1 teve maior tempo de duração com 390 dias, enquanto que o ensaio CP - 2 teve 352 dias de duração. O CP - 1 apresentou valores de condutividade hidráulica menor, da ordem de $3,5 \times 10^{-11} \mathrm{~m} / \mathrm{s}$ e o $\mathrm{CP}-2$ valores de $7,7 \times 10^{-11} \mathrm{~m} / \mathrm{s}$. Nota-se também uma equivalência nos gráficos dos ensaios nos trechos em que as curvas de condutividade hidráulica apresentam comportamento estável, no intervalo de 23 a $47 \mathrm{Vp}$, diferindo os valores obtidos de $K$.

O aumento nos valores de condutividade hidráulica durante os ensaios após a injeção de solução de $\mathrm{KCl}$ pode estar relacionada com a influência dos fatores físico-químicos. Isso pode ser explicado pela mudança na estrutura do solo devido às características da solução percolante. De acordo com Boscov (2008), as alterações na condutividade hidráulica causadas pela percolação de substâncias químicas são influenciadas pelas forças de repulsão entre as partículas de argila. Essas forças repulsivas controlam o comportamento de floculação, dispersão, contração e expansão. As forças que atuam entre as partículas são envolvidas pela camada dupla, cuja espessura depende de vários fatores, entre eles o $\mathrm{pH}$ do fluido, a adsorção de ânions na superfície das argilas e a temperatura. Portanto, analisar o comportamento do $\mathrm{pH}$ durante essas fases do ensaio é importante para verificar a procedência do aumento da condutividade hidráulica.

Em relação aos valores obtidos por Musso (2008), os valores de $K$ não sofreram diferenças significativas. $\mathrm{O}$ autor obteve um $K$ de $6,7 \times 10^{-11} \mathrm{~m} / \mathrm{s}$ para o ensaio com amostra de 
solo compactado, e um $K$ de $1,5 \times 10^{-11} \mathrm{~m} / \mathrm{s}$ para a amostra de GCL. Esses valores são considerados adequados para o uso como barreira de acordo com as normas dos órgãos ambientais.

Em geral, a combinação de amostras de solo compactado ao GCL nas duas configurações analisadas apresenta bom desempenho frente às soluções contaminantes mantendo valores aceitáveis pelas normas e regulamentações de implantação de barreiras impermeabilizantes. A configuração do ensaio CP-1, com GCL acima da camada de solo compactado, apresentou valores de condutividade hidráulica menores, confirmando o melhor desempenho como barreira hidráulica. No entanto, analisando somente o comportamento hidráulico do liner composto em relação aos materiais trabalhados independentes, a configuração do CP-1 apresentou condutividade hidráulica menor quando comparado somente com o solo compactado. No entanto, Musso (op. cit.) obteve para o GCL valores de condutividade hidráulica menor com relação às duas configurações analisadas nesta pesquisa, assim como, com relação ao solo.

\subsection{Variação de $\mathrm{Na}^{+}$}

Na fase de saturação com água destilada/deionizada do ensaio $\mathrm{CP}$ - 1 verificou-se uma redução na concentração de $\mathrm{Na}^{+}$confirmando a lixiviação desse íon. No ensaio $\mathrm{CP}-2$ esse comportamento foi crescente. Isso pode ser justificado pela configuração analisada, onde o GCL encontra-se abaixo da camada de solo compactado. Portanto, a lixiviação aumentou a concentração de $\mathrm{Na}^{+}$na solução efluente devido à bentonita do GCL ser sódica. Foi possível verificar também valores crescentes de condutividade elétrica nessa fase, uma vez que houve aumento da concentração de íons na solução efluente.

$\mathrm{Na}$ fase de percolação com solução contaminante de $\mathrm{KCl}$ ocorreu uma gradativa redução de $\mathrm{Na}^{+}$, com valores muito próximos de zero em ambas as configurações analisadas. Os gráficos apresentaram semelhança nesta fase, com comportamento crescente de lixiviação nos primeiros $10 \mathrm{Vp}$. Após este trecho até percolar $30 \mathrm{Vp}$, o gráfico apresentou comportamento decrescente acentuado, e em seguida os valores ficaram muito próximos de zero. 


\section{$5.3 \mathrm{pH}$}

$\mathrm{Na}$ fase de saturação com água destilada/deionizada o $\mathrm{pH}$ se mostrou maior do que o $\mathrm{pH}$ obtido na fase de percolação com solução de $\mathrm{KCl}$. A partir dos gráficos de $\mathrm{pH}$ versus volume de vazios percolados é possível notar que há uma tendência geral de redução de na fase de percolação com solução de $\mathrm{KCl}$. Tal redução pode estar relacionada com a substituição do próton $\mathrm{H}^{+}$ligados às hidroxilas expostas na superfície das partículas de solo por cátions, como o $\mathrm{K}^{+}$, em solução tornando-a mais ácida (Shackelford \& Redmond, 1995). Os autores comentam ainda que este fato confirma a influência efetiva da troca iônica como processo dominante.

A água destilada/deionizada utilizada na saturação dos corpos-de-prova apresentou valore de $\mathrm{pH}$ de 5,8 e o pH da solução de $\mathrm{KCl}$ foi de 4,9. Como visto nas Figuras 4.10 e 4.11, após a percolação nos corpos-de-prova o pH da água aumentou. No ensaio CP - 1, após a injeção da solução de $\mathrm{KCl}$, o pH da solução efluente aumentou, e no decorrer do ensaio apresentou uma redução com valores entre 7,1 e 7,5. No ensaio CP - 2, ocorreu redução do pH na solução efluente logo após a passagem da solução de $\mathrm{KCl}$, com valores muito próximos dos apresentados no ensaio $\mathrm{CP}-1$, entre 7,1 e 7,5. Mesmo com essa redução, o pH da solução efluente foi superior ao $\mathrm{pH}$ da solução influente de $\mathrm{KCl}$. Este fato indica que o solo liberou $\mathrm{OH}^{-}$e alcalinizou o efluente. Essa redução no $\mathrm{pH}$ também pode explicar o aumento na condutividade hidráulica de ambos os ensaios, pois apresentam mudança de comportamento no mesmo instante.

\subsection{Condutividade elétrica (CE)}

A condutividade elétrica permite verificar a concentração salina das soluções, sendo tanto maior quanto for a concentração das soluções eletrolíticas. Diante de tal comportamento, é possível acompanhar as variações das concentrações eletrolíticas das soluções efluentes de cada ensaio. Contudo, através dos valores de condutividade elétrica são controlados os níveis de lavagem e retenção dos eletrólitos pelo solo (Boff, 1999).

Observa-se que após a passagem da solução de $\mathrm{KCl}$ ocorreu um aumento na condutividade elétrica com alguns valores superiores aos valores da solução influente. No CP - 1, a condutividade elétrica atinge estabilização em $23 \mathrm{Vp}$, com valores entre 2650 e 2700 $\mu$ mho.cm ${ }^{-1}$. No CP -2 , após atingir $23 \mathrm{Vp}$, a condutividade elétrica atinge estabilização com 
valores na faixa de $2800 \mu$ mho.cm ${ }^{-1}$. Em aproximadamente $50 \mathrm{Vp}$, ocorre uma leve redução com nova estabilização. Os valores de condutividade elétrica para este ensaio finalizam-se em torno de 2700 a $2800 \mu$ mho.cm ${ }^{-1}$.

Nota-se que após a passagem da solução de $\mathrm{KCl}$ a condutividade elétrica aumentou e em seguida estabiliza-se em ambos os ensaios. Neste momento a concentração de $\mathrm{Na}^{+}$no efluente é praticamente nula, indicando que a concentração da solução no efluente está próxima da influente. Com relação à concentração salina, pode-se dizer que esta encontra-se alta e os sais presentes no meio aquoso foram pouco lixiviados.

\section{$5.5 \mathrm{Eh}$}

De acordo com Bourg \& Loch (1995, apud Boff, 1999), os parâmetros Eh e pH estão atrelados um ao outro, cujo comportamento de ambos segue uma tendência contrária. Ou seja, a medida que o $\mathrm{pH}$ diminui, o Eh aumenta , e vice-versa. Os autores afirmam que o potencial redox pode induzir fortemente na acidificação ou na alcalinização do solo e de outros sistemas aquáticos. Desta forma, componentes oxidantes tendem a induzir a acidez (diminuir o $\mathrm{pH}$ ) enquanto que componentes redutores induzem a elevação da alcalinidade.

As curvas de $\mathrm{pH}$ e Eh dos ensaios realizados permitem constatar a tendência oposta, ou seja, a medida que o Eh cresce, o pH tende a diminuir. Essa tendência de aumento no potencial redox durante o tempo favorece a existência de espécies químicas com menos elétrons e meios oxidantes induzidos pela acidez (Basso, 2003).

\subsection{Curvas de chegada}

O ensaio CP - 1, onde o GCL foi colocado acima da camada de solo compactado, foi realizado inicialmente com pressão de $100 \mathrm{kPa}$ e gradiente hidráulico de 465. Porém, como a velocidade do ensaio não estava compatível com o tempo da pesquisa, fez-se necessário aumentar a pressão para $150 \mathrm{kPa}$ com gradiente hidráulico de 698 . O aumento na pressão ocorreu após a percolação com solução de $\mathrm{KCl}$ em aproximadamente $8 \mathrm{Vp}$.

$\mathrm{Na}$ pressão de $100 \mathrm{kPa}$ foram necessários cerca de 4 dias para recolher de $1 / 2$ a $1 / 4$ de volume de vazios percolados do corpo-de-prova. Quando a pressão aplicada passou para 150 $\mathrm{kPa}$, o intervalo de coleta de solução diminuiu, sendo realizado de 3 a 2 dias. 
O tempo de ensaio do $\mathrm{CP}$ - 1 na fase de percolação de $\mathrm{KCl}$ foi de 294 dias, com 44 volumes de vazios percolados até o momento em que o potássio atingiu $\mathrm{C} / \mathrm{C}_{0}=0,95$. $\mathrm{O}$ ensaio CP-2 atingiu o estado estacionário de $\mathrm{C} / \mathrm{C}_{0}=1$ para os íons estudados com duração de 230 dias na fase de percolação com $\mathrm{KCl}$, em $64 \mathrm{Vp}$.

É possível notar que as curvas de chegada dos íons estudados mostram que as concentrações iônicas finais praticamente atingiram a concentração inicial. Observa-se que a curva de chegada do potássio para as duas configurações ensaiadas apresentam comportamento similar, com a estabilização próxima de alcançar a saturação química. A curva de chegada do potássio no ensaio CP - 1 atinge o comportamento estável de concentração relativa $\mathrm{C} / \mathrm{C}_{0}=0,95 \mathrm{em} 44 \mathrm{Vp}$. Após este ponto os valores mostraram maior dispersão. Depois do acréscimo na pressão para $150 \mathrm{kPa}$, a curva de chegada do potássio apresentou um comportamento crescente retilíneo por $15 \mathrm{Vp}$ até atingir estabilização. Isso pode ser evidenciado na curva de condutividade hidráulica, que nesse mesmo trecho apresentou comportamento crescente devido ao aumento da pressão. Nessas mesmas condições, a curva de chegada do $\mathrm{Cl}^{-}$apresentou comportamento totalmente diferente em relação à curva de chegada do íon $\mathrm{K}^{+}$. Nota-se que o $\mathrm{Cl}^{-}$atinge $\mathrm{C} / \mathrm{C}_{0}=1$ em aproximadamente $8 \mathrm{Vp}$.

Já no ensaio CP - 2, onde o GCL foi colocado abaixo da camada de solo compactado, a pressão de $100 \mathrm{kPa}$ foi mantida durante todo ensaio. Para a coleta de $1 / 2$ a $1 / 4$ de volume de vazios percolado foram necessários cerca de 2 a 1 dia.

A Figura 5.1 apresenta as curvas de chegada do $\mathrm{K}^{+}$nas duas configurações analisadas para visualização do comportamento desse íon. Verifica-se uma diferença entre as curvas no tempo em que o $\mathrm{K}^{+}$levou para atingir $\mathrm{C} / \mathrm{C}_{0}=95$. Essa diferença ocorre no trecho de percolação entre 10 a $30 \mathrm{Vp}$. Neste momento observa-se que o $\mathrm{K}^{+}$no $\mathrm{CP}-1$ apresenta um atraso com relação ao $\mathrm{K}^{+}$do CP-2. Portanto, o CP-1 levou 294 dias para atingir 95\% da concentração inicial em $44 \mathrm{Vp}$, enquanto que o CP-2 levou 185 dias em 50Vp. Isso pode ser explicado talvez, pela velocidade linear média, o que implica em maior tempo de ensaio. Vale ressaltar ainda que após atingir a concentração relativa de 95\%, as curvas apresentaram comportamento disperso quanto as concentrações. Dessa maneira, pode-se afirmar que após 300 dias o ensaio do CP-1 poderia ser finalizado, sem necessidade de seguir por mais tempo. 


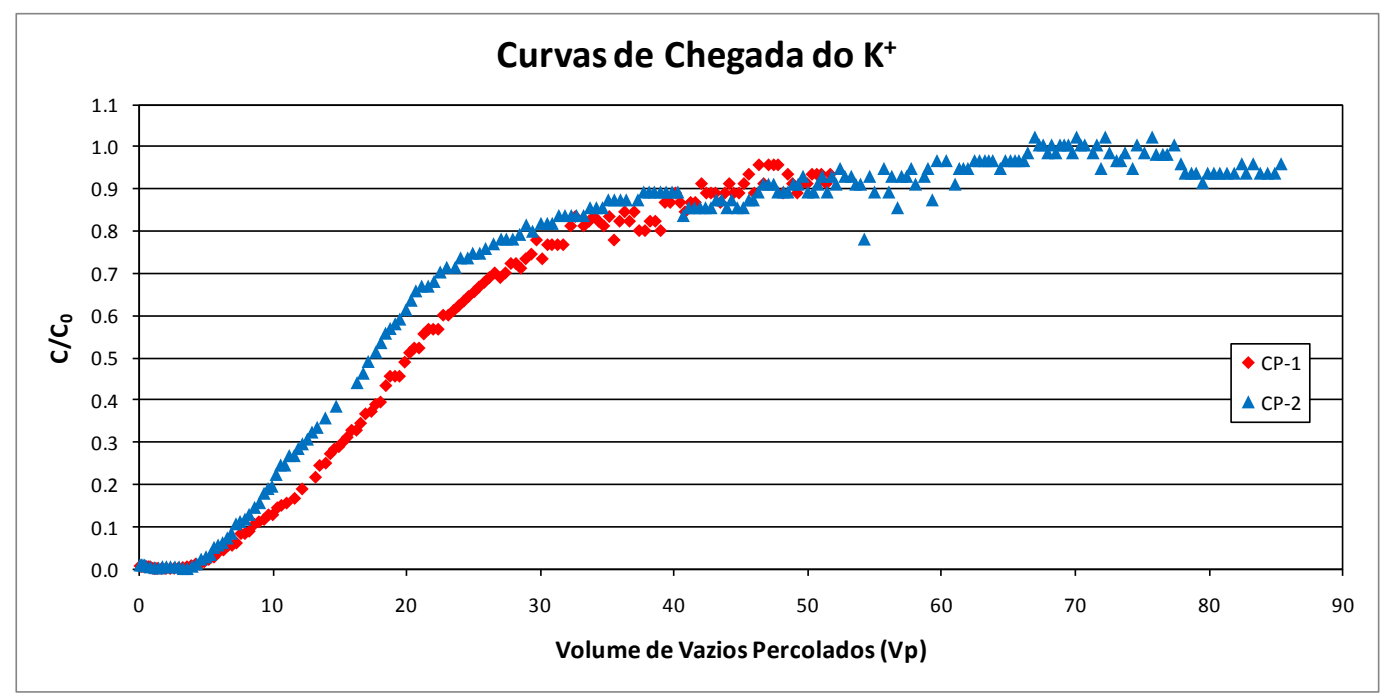

Figura 5.1 - Curva de chegada do $\mathrm{K}^{+}$nos corpos-de-prova ensaiados.

$\mathrm{O}$ íon $\mathrm{Cl}^{-}$apresentou uma retenção significativa na configuração do ensaio $\mathrm{CP}-2$ com $19 \mathrm{Vp}$ para atingir a concentração inicial. Enquanto que no $\mathrm{CP}-1$ este ânion atinge $\mathrm{C} / \mathrm{C}_{0}=1 \mathrm{em}$ apenas $8 \mathrm{Vp}$. Esta retenção de $\mathrm{Cl}^{-}$não é esperada em ensaios de coluna. Esse comportamento é constatado também nos ensaios realizados na amostra de solo por Musso (2008). Observa-se uma maior retenção do $\mathrm{Cl}^{-}$na configuração onde o solo encontra-se acima do GCL (CP-2), o que pode indicar uma maior influência da camada inicial no comportamento geral do liner composto.

Tabela 5.1 - Resultado do comportamento dos ensaios desta pesquisa.

\begin{tabular}{|c|c|c|c|c|c|c|}
\hline & \multicolumn{6}{|c|}{ Pesquisa Atual } \\
\hline & \multicolumn{2}{|c|}{ CP-1 (GCL+Solo) } & \multirow{2}{*}{$\begin{array}{c}\text { Tempo } \\
\text { (dias) }\end{array}$} & \multicolumn{2}{|c|}{ CP-2 (Solo+GCL) } & \multirow{2}{*}{$\begin{array}{c}\text { Tempo } \\
\text { (dias) }\end{array}$} \\
\hline & $\mathrm{C} / \mathrm{C}_{0}$ & $\mathrm{~V}_{\mathrm{p}}$ & & $\mathrm{C} / \mathrm{C}_{0}$ & $\mathrm{~V}_{\mathrm{p}}$ & \\
\hline \multirow{2}{*}{$\mathrm{K}^{+}$} & \multirow{2}{*}{0,95} & \multirow{2}{*}{44} & \multirow{2}{*}{294} & 1 & 64 & 230 \\
\hline & & & & 0,95 & 50 & 185 \\
\hline $\mathrm{Cl}^{-}$ & 1 & 8 & 99 & 1 & 19 & 97 \\
\hline
\end{tabular}

Nos ensaios realizados por Musso (op. cit.) as pressões aplicadas variaram de 75 a 86 $\mathrm{kPa}$, com coleta de $1 / 2$ a $1 / 4$ volumes de vazios percolados a cada 24 horas. De acordo com as Figuras 5.2 e 5.3 as curvas de chegada do íon $\mathrm{Cl}^{-}$para o ensaio no solo compactado, atingiu a concentração relativa de $\mathrm{C} / \mathrm{C}_{0}=1 \mathrm{em} 17 \mathrm{Vp}$, enquanto que para o ensaio no GCL o valor foi rapidamente atingido com a percolação de apenas 3,5 Vp. Para o íon $\mathrm{K}^{+}$, a concentração relativa de $\mathrm{C} / \mathrm{C}_{0}=0,95$ ocorreu após a percolação de $45 \mathrm{Vp}$ (200 dias) no solo compactado. Com o GCL, a estabilização da concentração de $\mathrm{K}^{+}$ocorre em 40 Vp (195 dias). 


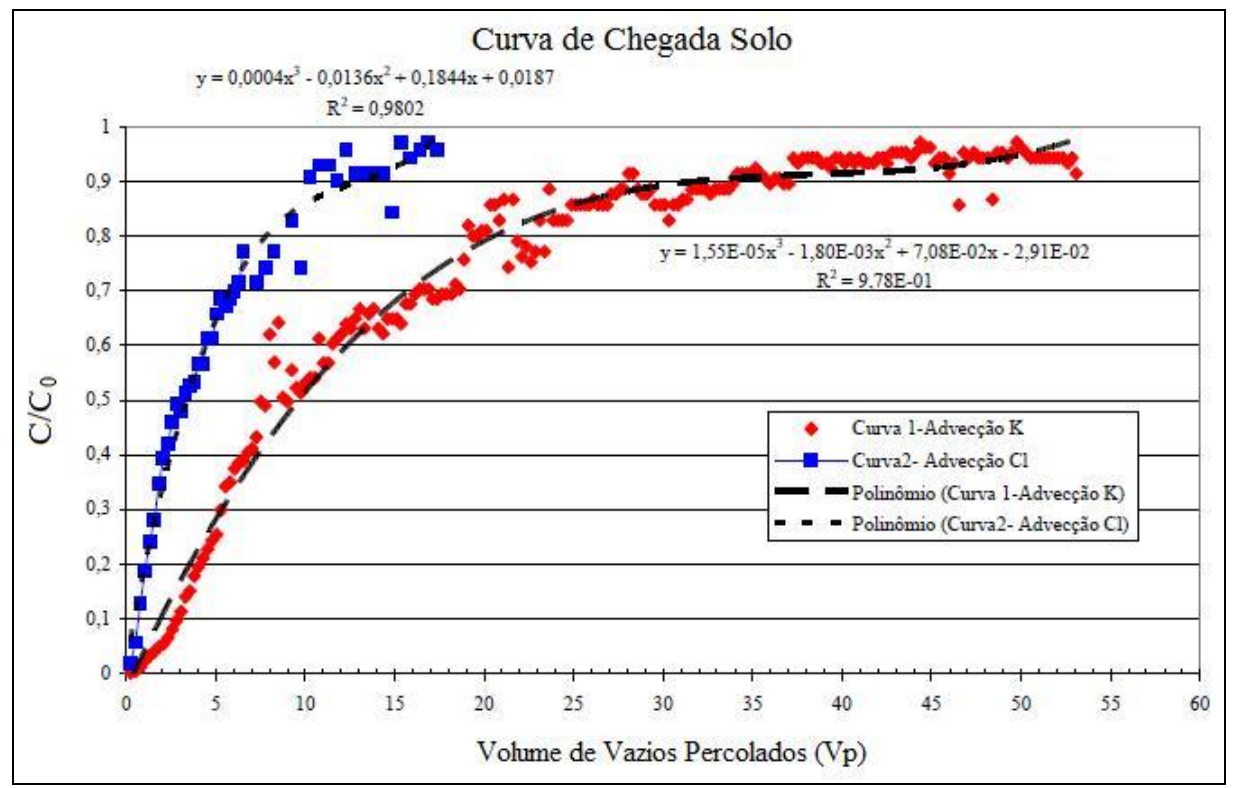

Figura 5.2 - Curva de chegada dos íons $\mathrm{K}+$ e Cl- para amostra de solo compactado obtida por Musso (2008).

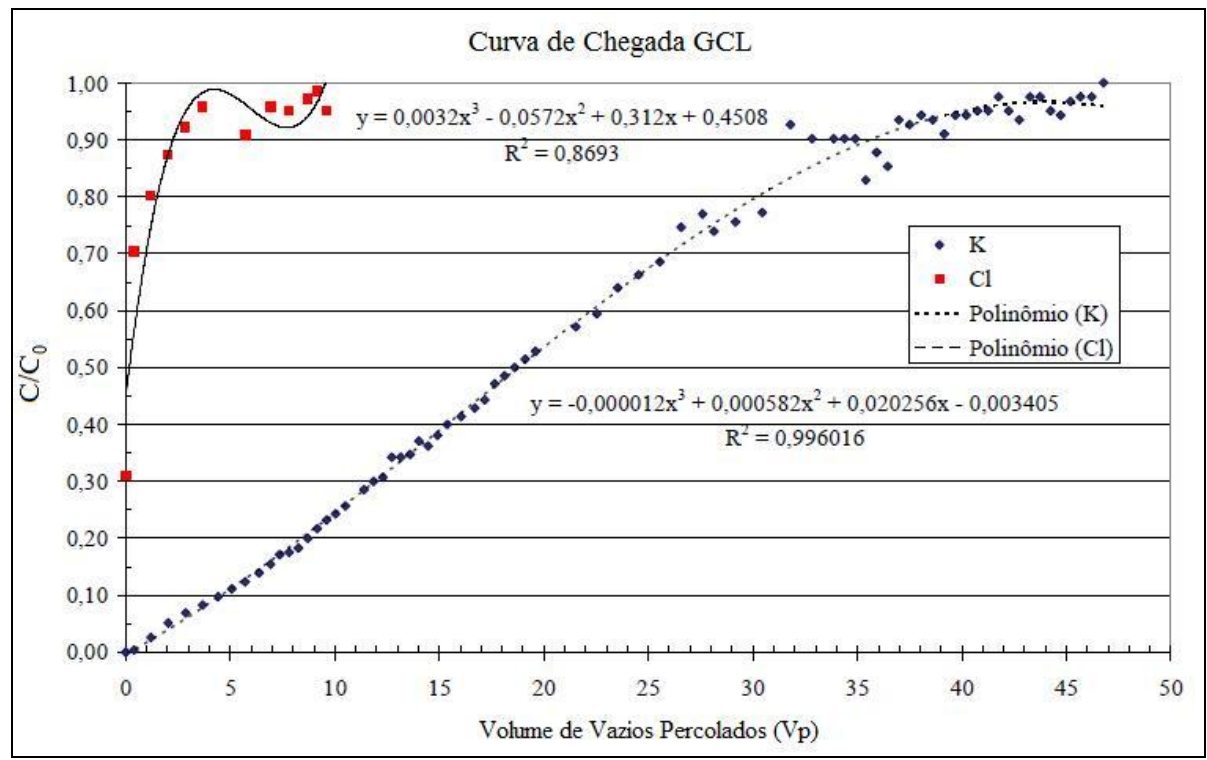

Figura 5.3 - Curva de chegada dos íons K+ e Cl- para o GCL obtida por Musso (2008).

Observa-se que a chegada do $\mathrm{K}^{+}$no GCL apresenta uma forma quase linear para $\mathrm{C} / \mathrm{C}_{0}=0,8$, semelhante ao que se espera de um transporte com pouca difusão. A Tabela 5.2 apresenta o comportamento dos íons estudados na pesquisa de Musso (2008). 
Tabela 5.2 - Resultados do comportamento dos ensaios de Musso (2008).

\begin{tabular}{|c|c|c|c|c|c|c|}
\hline & \multicolumn{5}{|c|}{ Musso (2008) } & \multirow{3}{*}{$\begin{array}{r}\text { Tempo } \\
\text { (dias) } \\
\end{array}$} \\
\hline & \multicolumn{2}{|c|}{ Solo } & \multirow{2}{*}{$\begin{array}{c}\text { Tempo } \\
\text { (dias) }\end{array}$} & \multicolumn{2}{|c|}{ GCL } & \\
\hline & $\mathrm{C} / \mathrm{C}_{0}$ & $V_{p}$ & & $\mathrm{C} / \mathrm{C}_{0}$ & $\mathrm{~V}_{\mathrm{p}}$ & \\
\hline $\mathrm{K}^{+}$ & 0,95 & 45 & 200 & 0,95 & 46 & 195 \\
\hline $\mathrm{CI}$ & 1 & 17 & 60 & 0,95 & 3,5 & 45 \\
\hline
\end{tabular}

Em termos de concentração relativa, os resultados obtidos nesta pesquisa quando comparados aos resultados de Musso (2008) mostram que as diferenças não são significativas. Porém, não se pode igualar o comportamento dos mesmos, pois as condições impostas à realização dos ensaios não foram totalmente iguais, como: pressão, gradientes hidráulicos e dimensões dos corpos-de-prova. Visto que, o autor realizou os ensaios em corpos-de-prova com dimensões diferentes das utilizadas nesta pesquisa, assim como menor pressão, o que implica em diferentes velocidades de fluxo e tempo mais curto do que o tempo dos ensaios aqui obtidos.

Em geral, a configuração do GCL acima do solo compactado (CP-1) mostrou melhor desempenho para os íons estudados, pois apresenta melhores condições de atenuação para o íon $\mathrm{K}^{+}$, como pode ser observado pela comparação das duas curvas de chegada apresentadas na figura 5.1. Nota-se também que o aumento de pressão para acelerar a velocidade do ensaio $\mathrm{CP}$ - 1 não comprometeu o desempenho da combinação desses materiais.

\subsubsection{Fator de retardamento}

O fator de retardamento $\left(R_{d}\right)$ foi calculado através dos critérios de Shakelford (1994), obtidos a partir do método de cálculo da área acima da curva de chegada. As Figuras 5.4 e 5.5 apresentam as curvas de chegada dos íons estudados nas devidas concentrações relativas para os ensaios realizados nas duas configurações com as linhas de tendência, equação do gráfico e $\mathrm{R}^{2}$. A Figura 5.6 apresenta a curva de chegada do $\mathrm{K}^{+}$para $\mathrm{C} / \mathrm{C}_{0}=0,95$ com os parâmetros do gráfico. Por meio dessa figuras foi possível fazer a análise comparativa entre os fatores de retardamento calculado para cada situação. 


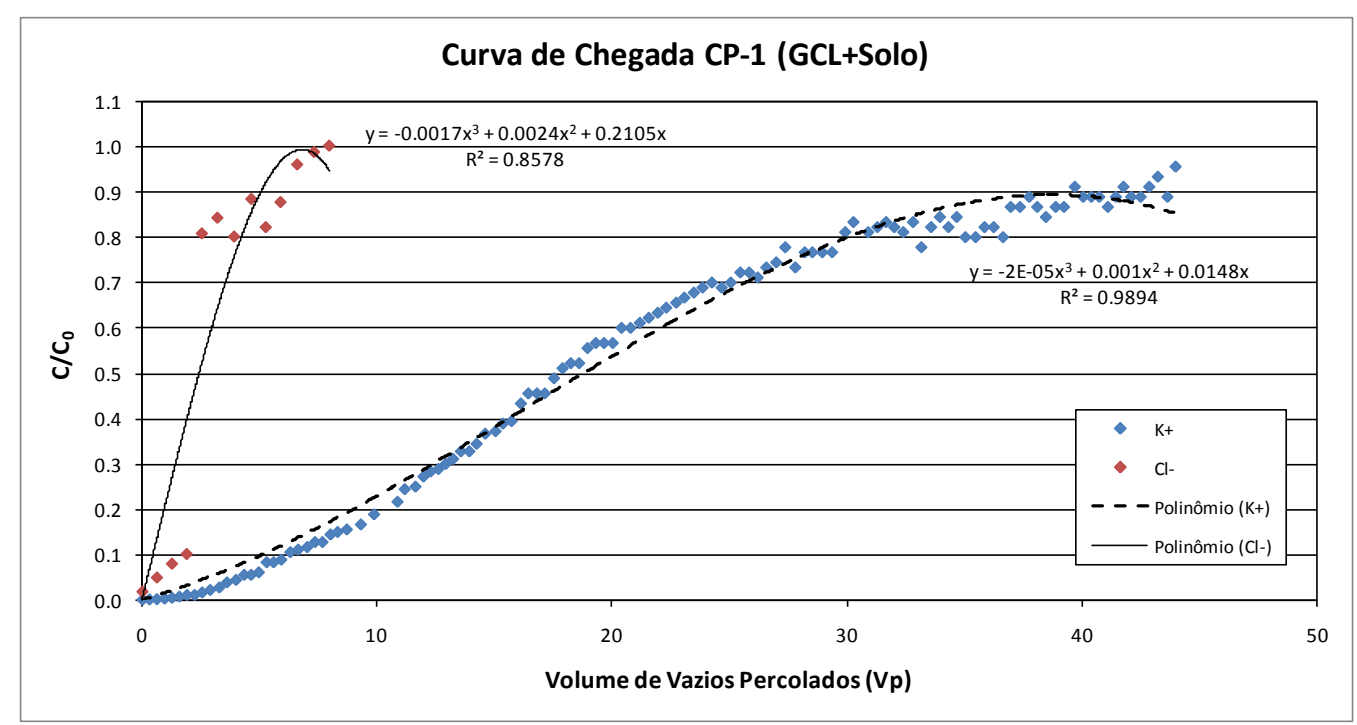

Figura 5.4 - Curva de chegada dos íons $\mathrm{K}^{+}$e $\mathrm{Cl}^{-}$do ensaio CP-1 para cálculo do fator de retardamento.

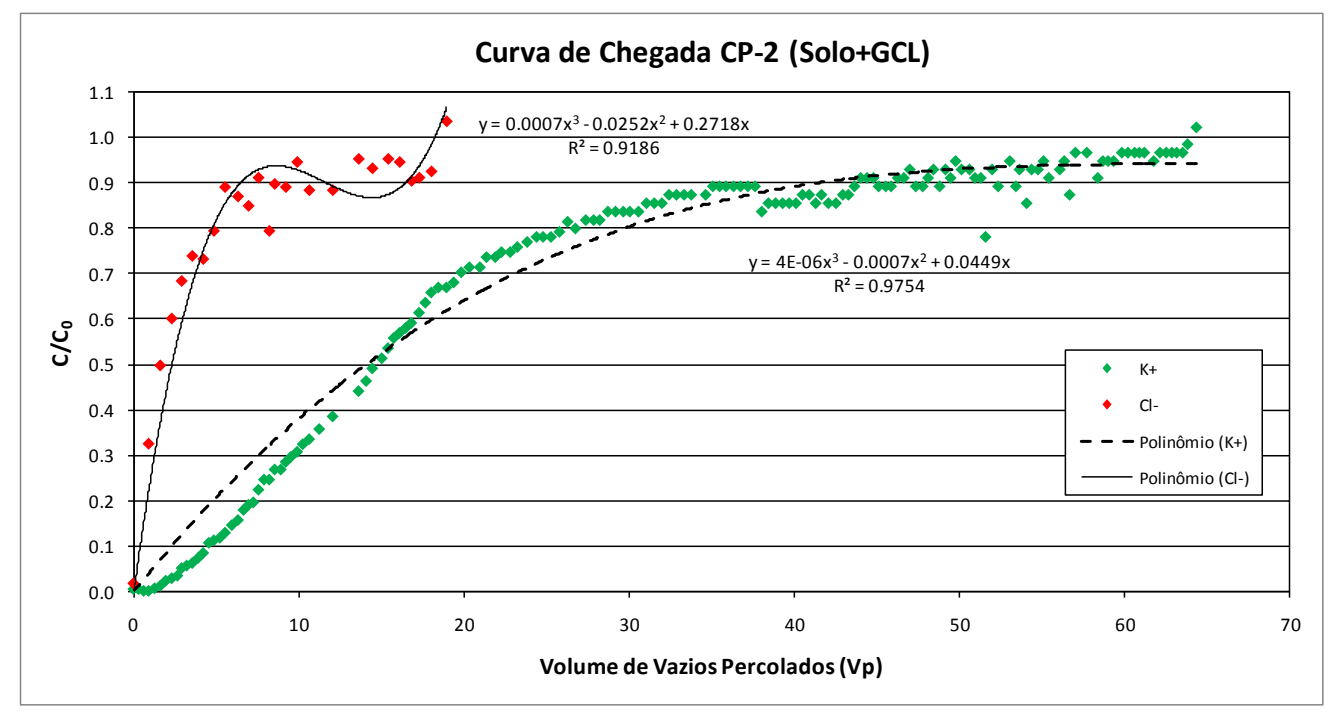

Figura 5.5 - Curva de dos íons $\mathrm{K}^{+}$e $\mathrm{Cl}^{-}$do ensaio CP-2 para cálculo do fator de retardamento. 


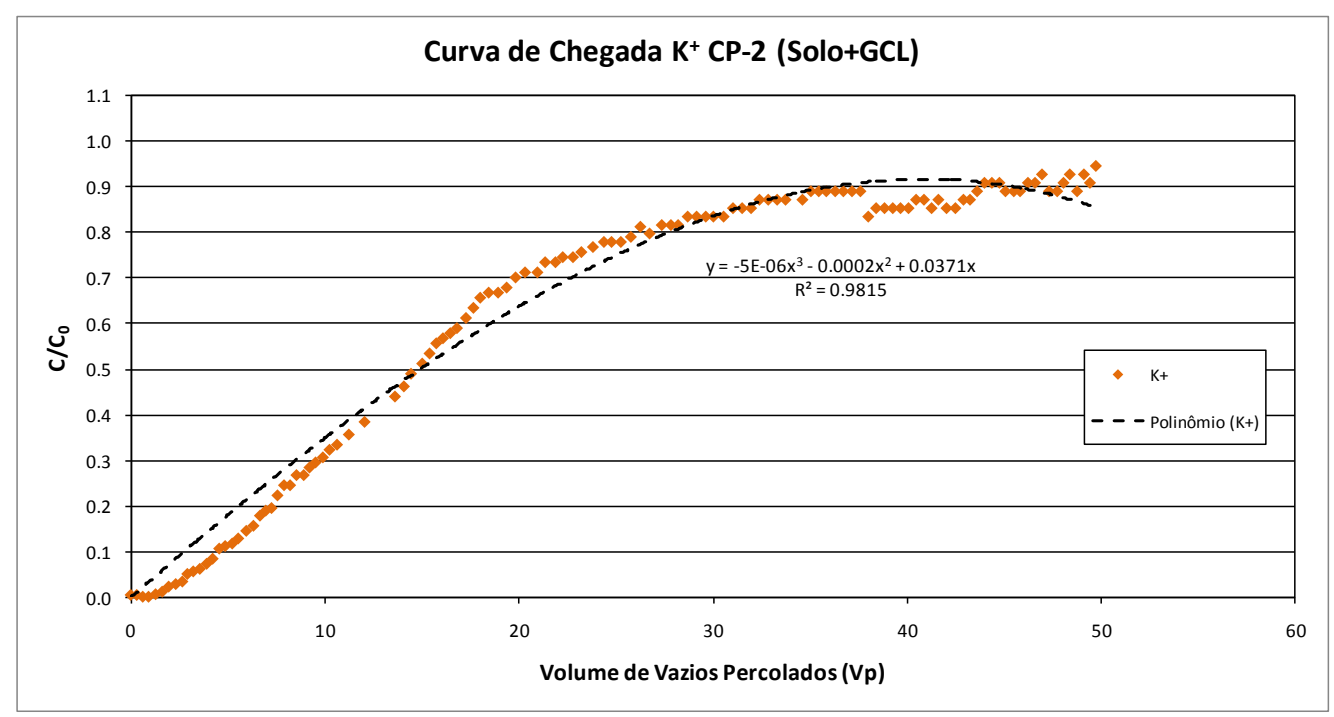

Figura 5.6 - Curva de do íon $\mathrm{K}^{+}$do ensaio $\mathrm{CP}-2$ com $\mathrm{C} / \mathrm{C}_{0}=0,95$ para cálculo do fator de retardamento.

O $R_{d}$ calculado para o íon potássio em $\mathrm{C} / \mathrm{C}_{0}=0,95$ apresentou uma diferença entre as duas configurações analisadas. $\mathrm{O}$ ensaio no $\mathrm{CP}-1$, onde o GCL encontra-se acima da camada de solo compactado, mostrou-se com maior fator de retardamento, correspondendo a 20,0. Enquanto que para a configuração do CP - 2, onde o GCL está abaixo da camada de solo compactado o $R_{d}$ foi de 19,7. É interessante assinalar que ensaios em coluna com baixa velocidade podem apresentar maiores fator de retardamento, pois proporcionam maior tempo de contato do contaminante com o material, consequentemente maior interação química. Este fato é verificado através do valor de $R_{d}$ para o $\mathrm{CP}-1$, confirmado pelo menor tempo de ensaio e menor velocidade de percolação. Isso confirma a melhor retenção do potássio na configuração do GCL acima da camada de solo compactado.

O íon cloreto apresentou menor retardamento se comparado ao potássio com valores de 2,6 para o $\mathrm{CP}-1$ e 5,4 para o $\mathrm{CP}-2$. No entanto, verifica-se que no ensaio $\mathrm{CP}-2$ ocorreu um adiamento na saída deste ânion, além do esperado, com mostra a figura 5.5. Este fato revela que esta retenção é considerável, constatando que esse elemento não pode ser considerado como traçador para os materiais estudados, pois apresenta capacidade de adsorção de ânions. 
Tabela 5.3 - Valores de $R_{d}$ obtidos nesta pesquisa.

\begin{tabular}{|c|c|c|c|c|c|c|}
\hline & \multicolumn{3}{|c|}{$\mathrm{CP}-1$} & \multicolumn{3}{|c|}{$\mathrm{CP}-2$} \\
\hline & $\mathrm{C} / \mathrm{C}_{0}$ & $\mathrm{~V}_{\mathrm{p}}$ & $\mathrm{R}_{\mathrm{d}}$ & $\mathrm{C} / \mathrm{C}_{0}$ & $\mathrm{~V}_{\mathrm{p}}$ & $\mathrm{R}_{\mathrm{d}}$ \\
\hline $\mathrm{K}^{+}$ & 0,95 & 44 & 20,0 & $\begin{array}{c}1 \\
0,95 \\
\end{array}$ & $\begin{array}{l}64 \\
50 \\
\end{array}$ & $\begin{array}{l}16,4 \\
19,7 \\
\end{array}$ \\
\hline $\mathrm{Cl}^{-}$ & 1 & 8 & 2,6 & 1 & 19 & 5,4 \\
\hline
\end{tabular}

Como se pode notar na Tabela 5.3 , os valores de $R_{d}$ calculados para o íon potássio da configuração CP-2 apresentaram diferença, visto que, a curva de chegada para a concentração relativa de $\mathrm{C} / \mathrm{C}_{0}=1$ deveria apresentar $R_{d}$ maior com relação à curva de chegada na concentração de $\mathrm{C} / \mathrm{C}_{0}=0,95$. Este fato pode ser explicado pela metodologia utilizada para o cálculo através da área acima da curva de chegada. Neste caso, o procedimento adotado para o cálculo utilizou o ajuste de uma curva aos pontos experimentais, gerando uma linha de tendência do tipo polinomial e sua equação. A área interna (abaixo da curva) foi calculada pela integral da equação polinomial obtida no ajuste da curva em intervalos de zero até o volume de vazios total necessário para atingir a concentração relativa de cada ensaio. E a área externa (acima da curva) foi determinada pela diferença entre a área total e a área interna. Portanto, a diferença entre os valores deve-se ao limite utilizado na integração e às equações das linhas de tendência obtidas diferentes para cada concentração relativa.

Musso (2008) determinou o fator de retardamento em ensaios de equilíbrio em lote (Batch Test) para o íon $\mathrm{K}^{+}$através das isotermas de Freundlich e Langmuir, e também pelo método da área acima da curva de chegada proposto por Shackelford (1994) para os íons $\mathrm{K}^{+} \mathrm{e}$ $\mathrm{Cl}^{-}$. Para efeito de comparação dos resultados desta pesquisa, serão levados em consideração apenas os resultados de $R_{d}$ calculados pelo método proposto por Shackelford (1994) apresentados na tabela 5.4. Os valores de $R_{d}$ encontrados para os materiais estudados pelo autor mostraram-se melhor somente para o GCL em relação ao potássio, correspondendo a 19,3. O $R_{d}$ calculado para o solo percolado com $\mathrm{Cl}^{-}$foi de 4 , e para o $\mathrm{K}^{+}$foi de 13,9 . O $R_{d}$ calculado para o GCL quando percolado pelo $\mathrm{Cl}^{-}$foi de 0,7 .

Tabela 5.4 - Valores de $R_{d}$ obtidos por Musso (2008).

\begin{tabular}{|c|c|c|c|c|c|c|}
\hline & \multicolumn{3}{|c|}{ Solo } & \multicolumn{3}{|c|}{ GCL } \\
\hline & $\mathrm{C} / \mathrm{C}_{0}$ & $V_{p}$ & $\mathrm{R}_{\mathrm{d}}$ & $\mathrm{C} / \mathrm{C}_{0}$ & $V_{p}$ & $\mathrm{R}_{\mathrm{d}}$ \\
\hline $\mathrm{K}^{+}$ & 0,95 & 45 & 13,9 & 0,95 & 46 & 19,3 \\
\hline $\mathrm{CI}$ & 1 & 17 & 4,0 & 0,95 & 3,5 & 0,7 \\
\hline
\end{tabular}


Portanto, as duas configurações analisadas nesta pesquisa mostraram melhores desempenhos em termos de retenção com relação à utilização somente do solo compactado como liner. Tendo em vista que o GCL quando trabalhado independente apresenta capacidade suficiente de atenuação.

\subsection{Extração de solução dos corpos-de-prova}

Após a finalização dos ensaios, as células de percolação foram desmontadas e os corpos-de-prova foram fatiados em somente duas camadas, visto que, a altura de camada de solo foi de $1,35 \mathrm{~cm}$. O volume de solução extraído das amostras de solo foi utilizado para análise química.

Como visto na Tabela 5.5, observa-se no ensaio $\mathrm{CP}-1$ que o $\mathrm{Cl}^{-}$teve um pequeno avanço em relação ao potássio na camada inferior, sendo que ambos não atingiram a concentração efluente. A concentração de $\mathrm{K}^{+}$na camada inferior correspondeu a $3 / 4$ da concentração do reservatório. Nas soluções extraídas do ensaio $\mathrm{CP}-2$ foi possível notar que a concentração dos íons na camada superior e inferior está muito próxima da concentração do reservatório. Este fato implica em considerar que os valores obtidos para o CP-1 são anômalos, pois não refletem com coerência a real concentração dos íons nos poros. Isso pode ser explicado por algum erro na leitura do equipamento, considerando o volume pequeno na extração de solução, que não permitiu a repetição das análises para comparação.

Tabela 5.5 - Concentração da solução extraídas das amostras de solo após os ensaios.

\begin{tabular}{ccccc|cccc} 
& \multicolumn{4}{c|}{$\mathrm{CP}-1$} & \multicolumn{4}{c}{$\mathrm{CP}-2$} \\
\cline { 2 - 9 } & $\mathrm{V}_{\mathrm{e}}$ & $\mathrm{K}^{+}$ & $\mathrm{Cl}$ & $\mathrm{W}(\%)$ & $\mathrm{V}_{\mathrm{e}}$ & $\mathrm{K}^{+}$ & $\mathrm{Cl}$ & $\mathrm{W}(\%)$ \\
\cline { 3 - 9 } Camada 1 & $7 \mathrm{ml}$ & 80,3 & 81,6 & 18,97 & $13 \mathrm{ml}$ & 93,6 & 94,0 & 19,04 \\
Camada 2 & $8 \mathrm{ml}$ & 75,8 & 80,2 & 15,89 & $9 \mathrm{ml}$ & 91,4 & 87,1 & 16,46 \\
\hline
\end{tabular}

Onde: $\mathrm{V}_{\mathrm{e}}$ - volume de solução extraído; $\mathrm{K}^{+}$- concentração de potássio; $\mathrm{Cl}^{-}$- concentração de cloreto; $\mathrm{W}(\%)$ - umidade depois de extrair.

Outra hipótese a ser considerada para a redução das concentrações de $\mathrm{K}^{+}$seria a presença de sítios de troca ainda disponíveis no solo. Como o intervalo de tempo entre o final da percolação e a extração da solução dos poros foi de no mínimo 8 horas, pode ter ocorrido ainda adsorção de $\mathrm{K}^{+}$, reduzindo a concentração do íon na água dos poros. 



\section{CONSIDERAÇÕES FINAIS E SUGESTÕES PARA FUTURAS PESQUISAS}

Os resultados de condutividade hidráulica apresentaram aumento após a passagem da solução de $\mathrm{KCl}$ nas duas configurações analisadas. Acredita-se que este aumento no $K$ possa estar relacionado com alguma alteração na estrutura interna das argilas dos materiais, pela diminuição do pH. No entanto, essas mudanças não afetaram o desempenho hidráulico, considerando-se ainda, que a combinação desses materiais apresentou compatibilidade química com a solução contaminante utilizada.

Em relação à condutividade hidráulica obtida por Musso (2008), os resultados dessa pesquisa não apresentaram diferenças significativas nos valores de $K$. Portanto, essas configurações de liners atendem aos critérios e normas de regulamentação de aterros quanto ao comportamento hidráulico.

O tempo de execução dos ensaios de advecção nas colunas analisadas teve duração de 352 a 390 dias (12 a 13 meses), considerando assim, que os ensaios foram de longo prazo. O equipamento utilizado mostrou-se satisfatório o que afirma a confiabilidade nos resultados.

No que diz respeito à capacidade de atenuação, o fator de retardamento das configurações analisadas mostraram-se superior aos obtidos por Musso (2008) para o solo compactado. A retenção do cloreto nas duas colunas confirma que este elemento não pode ser considerado traçador para os materiais estudados. A combinação do GCL acima da camada de solo argiloso apresentou ligeira vantagem quanto à capacidade de adsorção por obter maior valor de $R_{d}$, o que implica em melhor desempenho em relação à outra configuração. 
Vale ressaltar ainda que os materiais que se encontram na camada superior das configurações analisadas exercem maior influência no comportamento do Liner composto quando percolados por solução contaminante, provavelmente por afetarem as características físico-químicas das soluções percolantes, o que pode acarretar em alterações na atenuação dos contaminantes nas camadas inferiores.

Como sugestão para trabalhos futuros, segue:

- Realizar ensaios em coluna com concentração iônica diferente da utilizada nesta pesquisa;

- Testar soluções de outros íons com diferentes forças iônicas;

- Automatizar as leituras de pH, Eh e condutividade elétrica das soluções de coleta, permitindo avaliar os resultados em tempo real;

- Determinar o coeficiente de dispersão hidrodinâmica para aprimorar a avaliação do comportamento dos íons estudados de acordo com a velocidade utilizada no ensaio. Assim como, determinar também outros parâmetros como o número de Peclet e coeficiente de distribuição. 


\section{REFERÊNCIAS BIBLIOGRÁFICAS}

ALONSO, T. P. (2005) "Condutividade hidráulica de solos compactados em ensaios com permeâmetro de parede flexível”. (Mestrado) 113p. Escola de Engenharia de São Carlos, São Carlos, São Paulo.

ABNT - Associação Brasileira de Normas Técnicas. (1987) Resíduos Sólidos: NBR 10004 63p Rio de Janeiro.

ASTM - AMERICAN SOCIETY FOR TESTING AND MATERIAL. (1990) ASTM D508490 - "Measurement of Hydraulic Conductivity of Saturated Porous Materials Using a Flexible Wall Permeameter".

BASSO, J. B. (2003) "Transporte e retenção de de $\mathrm{K}+, \mathrm{Cu} 2+$ e $\mathrm{Cl}-$ em uma mistura compactada de solos lateríticos para uso em barreiras selantes: procedimentos de homogeneização da mistura e adaptações em equipamentos de percolação em coluna". (Mestrado) 168p. - Escola de Engenharia de São Carlos, Universidade de São Paulo.

BEAR, J. (1972) "Dynamics of fluid in porous media", New York, American Elsevier.

BEDIENT, P. B; RAFAR, H. L.; NEWELL, C. J. (1994) “Ground Water Contamination Transport and remediation”. Prentice Hall. Chiff, New York.

BOFF F. E. (1999) “Avaliação do Comportamento de uma mistura compactada de solos lateríticos frente a soluções de $\mathrm{Cu} 2+, \mathrm{K}+$ e $\mathrm{Cl}$ - em colunas de Percolação". (Mestrado) 180 pp. Escola de Engenharia de São Carlos, Universidade de São Paulo, São Carlos, São Paulo. 
BOSCOV, M. E. G.; OLIVEIRA, E.; GHILARDI, M. P. \& SILVA M. M. (1999) "Difusão de metais através de uma argila laterítica compactada". REGEO 99, 4 Congresso Brasileiro de Geologia Ambiental, pp.323-330.

BOSCOV, M. E. G. (1997) "Contribuição ao projeto de contenção de resíduos perigosos utilizando solos lateríticos”. ( Doutorado), Escola Politécnica, USP, São Paulo.

BOSCOV, M. E. G. (2008) “Geotecnia Ambiental”. São Paulo: Oficina de Textos, 248p.

BOUTWELL, G., \& HEDGES, S. (1989) "Evaluation of waste retention liners by multivariate statistics". Proc. 12th ICSMFE. Balkema, Rotterdam, The Netherlands, pp.815818.

BUENO, B. S., VILAR, O. M., PALMA, S. L. E PIMENTEL, V. E. (2002) "Laboratory studies for development of a GCL". Zanzinger, Koener y Gartung (eds.) Clay Geosynthetic Barriers. 365-370. ISBN 9058093808.

CETESB - COMPANHIA DE TECNOLOGIA DE SANEAMENTO AMBIENTAL (1993) "Resíduos Sólidos Industriais", 2ed. rev. ampl., São Paulo.

DANIEL, D. E. e BENSON, C. H. (1990) "Water Content-Density Criteria for Compacted Soil Liners", Journal of Geotechnical Engineering, ASCE, Vol. 116, No. 12, p.1811-1830.

DANIEL, D. E. (1993) “Clay Liners” In: DANIEL, D.E. ed. Geotechnical Pratice for Waste Disposal, London, Chapman \&Hall, Chapter 1, p.3-14.

DOURADO, K.A; VILAR, O. M. (2003). “Condutividade Hidráulica de Materiais de Baixa Permeabilidade: Desenvolvimento, Construção e Teste de um Sistema de Medida". (Mestrado) 89p, Escola de Engenharia de São Carlos,.

FERRARI, A. A. P. (2005) "Viabilidade da utilização de silte compactado como material de impermeabilização em aterro de resíduos”. (Mestrado) Escola Politécnica da Universidade de São Paulo, São Paulo.

FREEZE, R. A.; CHERRY, J. A. (1979) “Groundwater”. Prentice-Hall, Inc., Englewoods Cliffs,N.J. 
FOLKES, D. J. (1982) "Control of contaminant migration by the use of liners". Canadian Geotechnical Jounal (Fifth Canadian Geotechnical Colloquium), v.19, p.320-344.

GRIM, R. E. (1953) “Clay Mineralogy”. New York: McGraw-Hill 384 p.

HUGHES, K. L.; CHRISTY, A. D.; HEIMLICH, J. E. (2005) "Landfill Types and Liner Systems" Extension Factsheet, The Ohio University, Columbus, OH. p.138.

INSTITUTO GEOLÓGICO E MINEIRO (2001). Água Subterrânea: Conhecer para Preservar o Futuro. Versão Online disponível em: http://e-Geo.ineti.pt/geociencias/edicoes_online /diversos/agua_subterranea/indice.htm. Acesso em: 24 de janeiro de 2008.

INSTITUTO DE PESQUISAS TECNOLÓGICAS DO ESTADO DE SÃO PAULO - IPT 1995 - Lixo Municipal. Manual de Gerenciamento Integrado. IPT, São Paulo - SP, 278 p.

JO, H.; BENSON, C.; LEE, J.; SHACKELFORD, C.; EDIL, T. (2005) "Long-term hydraulic conductivity of a non-prehydrated geosynthetic clay liner permeated with inorganic salt solutions. Journal of Geotechnical and geoenvironmental Engineering, ASCE, 131.

JESUS, S. C.; (2004) "Difusão de zinco em camada compactada de solo residual de gnaisse". Universidade Federal de Viçosa, Viçosa - MG.

KOERNER, R. M. (1999) "Designing with geosynthetics" - Fouth Edition. Prentice Hall, N.J.

LAMBE, T. W. (1958) “The engineering behavior of compacted clay”. Journal of Soil Mechanics and Foundation Division, ASCE, v.84, SM2, p. 16551- 165535.

LANDIM, P. M. B. (1967) "Grupo Passa Dois na Bacia do Rio Corumbataí" (Doutorado) Escola de Engenharia de São Carlos, São Carlos, São Paulo.

LAMBE, T. W.; WHITMAN, R. E. (1969) “Soil Mechanics”. John Wiley \& Sons, New York.

LEITE, A. L. (1997) “A difusão molecular do K+ e Cl em solos naturais compactados : uma perspectiva para uso em liners". (Dissertação de Mestrado), Escola de Engenharia de São Carlos, Universidade de São Paulo. 
LEITE, A. L. (1998) "Avaliação da variabilidade da difusão molecular em solos naturais compactados: uma perspectiva para uso em liners". Revisão Bibliográfica. Escola de Engenharia de São Carlos.

LEITE, J. C. (2000). "Estudos laboratoriais de percolação em colunas de misturas de solos lateríticos compactadas: equipamentos e ensaios”. (Doutorado) Escola de Engenharia de São Carlos, Universidade de São Paulo.

LEITE, A. L. (2001) "Migração de íons inorgânicos em alguns solos tropicais em ênfase nos processos de sorção e difusão molecular”. (Doutorado) Escola de Engenharia de São Carlos, Universidade de São Paulo, São Carlos, São Paulo.

LUKIANTCHUKI, J. A. (2007) "Influência do teor de bentonita na condutividade hidráulina e na resistência ao cisalhamento de um solo arenoso utilizado como barreira impermeabilizante". (Mestrado), Escola de Engenharia de São Carlos, Universidade de São Paulo, São Carlos, São Paulo.

MACKENZIE, R. C. (1957) “The differential Thermal Investigation of clays”. Mineralogical Society (Clay Mineral Group) - London.

MANASSERO M., BENSON C., BOUAZZA A. (2000) "Solid waste containment systems". Proceedings of the International Conference on Geological \& Geotechnical Engineering. GeoEng2000, Melbourne, volume 1, pp 520-642

MASSAD, F. (2003) “Obras de Terra - Curso Básico”, Oficina de Textos, São Paulo.

MESRI, G.; OLSON, R. E.; (1971) "Mechanisms controlling the permeability of clays". Clays and Clay Minerals, ,Vol. 19, pp. 151-158.

MITCHELL, J. K.; HOOPER, D. R.; CAMPANELLA, R. G.; (1965) "Permeability of compacted clay". Journal of Soil Mechanics and Foundation Div. ASCE, v.91 , n.4 , p.41-65.

MITCHELL, J. K. (1993) "Fundamentals of Soil Behavior", 2 edn, John Wiley \& Sons, New York.

MUSSO, M. (2008) "Transporte de solutos em barreiras de material argiloso compactado (CCL) e geocomposto bentonítico (GCL): fluxos diretos, acoplados e comportamento 
membrana”. 2008227 p. (Doutorado) Escola de Engenharia de São Carlos, Universidade de São Paulo, São Carlos, São Paulo.

NASCIMENTO, D. (2008) "Estudo químico do solo e lixiviado do aterro controlado de Botuquara”. (Mestrado) Universidade Estadual de Ponta Grossa, Ponta Grossa.

OBER (Boletim Técnico) Versão online: http://www.ober.com.br/produtos/pdfsgeo/geofortrecapeamento.pdf Acesso: 26 de agosto de 2009.

OLIVEIRA, S. H. (2002) “Avaliação do uso de borra oleosa processada em sistemas de impermeabilização de aterros". (Mestrado) Pontíficia Universidade Católica do Rio de Janeiro, Rio de Janeiro.

OLSEN, H. W. (1962) "Hydraulic flow through saturated clay Clay and Clay minerals". v.9 n.2 p 131-161

PEJON, O. J. (2007) "Migração de poluentes em liners de argila compactada considerando o efeito membrana". Relatório de Pesquisa, Conselho Nacional de Desenvolvimento Científico, CNPQ, São Carlos, São Paulo.

PINTO, C. S. (2002) “Curso básico de Mecânica dos Solos” em 16 aulas. Ed. Oficina de Textos. p.105.

ROWE, R. K.; QUIKLEY, R.M.; BOOKER, J. R. (1995) “Clayey Barrier Systems for Waste Disposal Facilities". London, E \& FN SPON.

ROWE, R. K (2000). “Geotechnical and Geoenvironmental Engineering Handbook”. Klwer Academic Publishers, 1088p.

ROWE, R. K. \& FRASER, M. J. (1993). "Composite Liners as Barriers: Critical Considerations". Proceedings, First International Congress on Environmental Geotechnics, Edmonton, Alberta, July.

ROWE, R. K. \& FRASER, M. J. (1995). "Effect of Uncertainty in the Assessment of the Potential Impact of Waste Disposal Facilities”. ASCE Geoenvironment 2000, New Orleans, Louisiana, February.

SANTOS, P. S. (1972) “Tecnologia das argilas”. São Paulo, EDUSP. 
SHARMA, H. D.; LEWIS, S. P. (1994) "Waste Containment Systems, Waste Stabilization, and Landfills: Design and Evaluation”. New York, John Wiley \& Sons.

SHACKELFORD C. D.; DANIEL, D. E. (1991) "Diffusion in satured soil. I: background". Journal of Geotechnical Engineering vol 117 nº 3 mar. 1991. p. 467-484.

SHACKEFORD, C.D. (1993) "Contaminant transport". In Geotechnical Practice for Waste Disposal, Daniel, D. E.Ed. London, Chapman and Hall”, p. 33-65.

SHACKELFORD, C. D. (1994). "Critical Concepts for Column Testing”. Journal of Geotechnical Engineering, ASCE, v.120, n.10, p.1804-1828, October.

SHACKELFORD, C. D. \& REDMOND, P. L. (1995) "Solute breakthrough curves for processed kaolin at low flow rates". Journal of Geotechnical Engineering, 121, 17-32.

SILVA, B. C. P.; VIDAL, D. M.; QUEIROZ, P. J. B.; (2004) "Efeitos da sorção no transporte de contaminantes orgânicos em solos argilosos". X ENCITA - Encontro de Iniciação Científica e Pós Graduação do Instituto Tecnológico da Aeronáutica.

STANCATI. G. (1991) "Estudo experimental do comportamento tensão-deformação de uma argila adensada unidirecionalmente". (Doutorado) 244 p. Escola de Engenharia de São Carlos, Universidade de São Paulo.

TCHOBANOGLOUS, G; THEISEN, H; ELIASSEN, R; (1977) "Solid Waste - Engineering Principles and Management Issues”. McGraw-Hill Publishing Company.

WEBER JR, W. J., MCGINLEY, P. M., \& LYNN, E. K., (1991) "Sorption Phenomena in Subsurface Systems: Concepts, Models and Effects on Contaminant Fate and Transport. Water”. Res., Vol. 25, No. 5, pp. 499-528.

YONG, R. N.; MOHAMED, A. M. O. \& WARKENTIN, B. P. (1992). "Principles of contaminant Transport in Soils”. Amsterdam: Elsevier Science Publishers B. V. 327p. 